\title{
VISUAL LAW AND LEGAL DESIGN: QUESTIONS AND TENTATIVE ANSWERS
}

\author{
Colette R. Brunschwig
}

Senior Research Associate, University of Zurich, Department of Law, Legal Visualization Unit Raemistrasse 74/52, 8001 Zurich, Switzerland

colette.brunschwig@rwi.uzh.ch, c.r.brunschwig@bluewin.ch

Keywords: visual law, legal design, visual legal-historical studies, visual legal theory, visual sociology of law, law-and visual art, law-and visual persuasion, law-and visual culture, law-and sight, legal communication design, legal product design, legal service design

Abstract: $\quad$ This paper rests on three premises: First, ongoing digitalization is unleashing visualization (still or moving images) and audiovisualization (videos, audiovisual animations, etc.). This massive technological development is also initiating multisensorization (humanoid robots, virtual realities, etc). Second, visual law and legal design are still largely unknown as fields of scholarly inquiry to many legal and non-legal actors. My paper therefore uses "visual law" and "legal design" as working terms to delineate these fields. Third, I take an etymological approach to the word "responsible" featuring in the conference title of the International Symposion on Legal Informatics 2020 as it implies a quality that is required of digitalization. The English adjective "responsible" comes from the Latin verb respondēre, whose meanings include answering (responding) and corresponding to something. Based on these premises, this paper explores four key questions: How does current legal research respond to visualization? What are visual law and legal design? How are visual law and legal design similar or different? What should visual lawyers or legal designers do to act responsibly in the face of ongoing digitalization? Tackling these questions yields new insights for the debate on legal visualization. The answers given in this paper reveal how various basic legal disciplines and law-and areas gravitate around this topic. The answers also demonstrate that the insights of the basic legal disciplines and law-and areas are or should be interconnected. Taking such steps will promote not only visualization itself but also interdisciplinary legal research on this important topic.

\section{Introduction}

This paper rests on three premises: First, ongoing digitalization is increasing the scale of visualization (still or moving images) ${ }^{1}$ and audiovisualization (e.g., videos, audiovisual animations). ${ }^{2}$ This massive technological development is also initiating multisensorization (e.g., humanoid robots and virtual realities). ${ }^{3}$

Second, many legal and non-legal actors are still unaware of visual law and legal design as fields of scholarly inquiry. I therefore use "visual law" and "legal design" as working terms to delineate these fields. Santuber, Krwawietz, Owoyele, and Edelman recently presented a "framework theory" of legal design. Its "elements are a complex systems approach, Luhmann's social systems theory and Iba's work on creative systems, as

\footnotetext{
See, e.g., Katsh, Law in a Digital World, 168; Feigenson and Spiesel, Law on Display, 1-33; Sherwin, Visualizing Law in the Age of the Digital Baroque, 13-55.

2 See, e.g., Katsh, 8; Feigenson and Spiesel, 1-33; Sherwin, Visualizing Law in the Age of the Digital Baroque, 13-55.

3 See, e.g., Brunschwig, "Law Is not or Must Not Be Just Verbal and Visual in the 21 $1^{\text {st }}$ Century," 246-53; id., "Humanoid Robots in Legal Education," 263-85; id., "Humanoid robots for contract visualisation," 142-60.
} 
well as design theory." Nevertheless, visual law and legal design remain largely undertheorized. Various attempts to describe and analyze visual law ${ }^{5}$ and legal design ${ }^{6}$ have been made: The title of my $\mathrm{PhD}$ thesis (2001) was Visualisierung von Rechtsnormen: Legal Design [Visualization of Legal Norms: Legal Design]. ${ }^{7}$ At the time, I regarded the visualization of legal norms as one of many subject matters that formed part of "an unknown and hence hazardous territory, which I called "legal design." " 8 Originally, I had intended to use "legal design" as the main title and "visualization of legal norms" as the subtitle of my book (yet did not receive my supervisor's permission). In hindsight, I suspect that my "unconventional" idea was too premature at the time. What I meant by "legal design" was verbal and verbo-visual legal communication design. I was unaware that I had "breached" the boundaries of a much larger legal territory that was waiting to be explored. Today, almost twenty years later, Perry-Kessaris describes legal design as "a nascent field of thinking and practices, the contours and content of which are emergent and contested." Central to this field is "a shared interest in how design-based methods and attitudes might be developed in relation to legal matters." 10 Thus, there is "a commitment to communication, an emphasis on experimentation, and an ability to make things visible and tangible." 11 Based on their framework theory, Santuber, Krawietz, Owoyele, and Edelman define legal design "as a network that articulates the coupling of autopoetic systems. The constructs are (a) human being, (b) creative process and (c) Law [sic]."12 They perceive legal design "as the redesign of legal systems."13 Hagan calls legal design a "thing," 14 an "approach," 15 whose purpose is "to improve the legal system." 16 She considers legal design "a nascent movement to make the legal system work better for people"17 or even a "discipline."18 While I am unsure whether I understand what Hagan means by "thing," 19 I grasp her intention to highlight the various ephemeral aspects of the term. These days, "legal design" seems to be a path that we need to take. In itself, the term alludes to an existing community and increasingly implies a field of legal study and practice. Legal design aims to improve the legal system. This goal involves, for instance, making the law "more accessible to lay people," serving "corporate professionals," and assisting "policy makers and government officials." ${ }^{20}$ Most publications on legal design are concerned with its applications. These include

4 Santuber, Krawietz, Owoyele, and Edelman, "A Framework Theory of Legal Design for the Emergence of Change in the Digital Legal Society," 56. See also ids., 44-48.

5 See Brunschwig, "On Visual Law"; Ducato, "De iurisprudentia picturata”; Curtotti, "Visualising a Visual Movement"; Mik, "The Limits of Visual Law."

6 On legal design, see, e.g., Rossi, "Legal Design for the General Data Protection Regulation," 96. Rossi provides a (working) definition of legal design and refers to Hagan's Law by Design (published online). As much as I respect Hagan's book, it neither explicitly draws on design research nor grounds its definition of legal design in the relevant literature. For a general discussion, see Hagan, Law by Design.

7 Brunschwig, Visualisierung von Rechtsnormen.

8 Brunschwig, "Contract Comics and the Visualization, Audio-Visualization, and Multisensorization of Law," 205.

9 Perry-Kessaris, "Legal Design for Practice, Activism, Policy, and Research,” 186.

10 Perry-Kessaris, 186.

Perry-Kessaris, 190.

12 Santuber, Krawietz, Owoyele, and Edelman, 50. This theory assumes that legal designers are always human beings. Yet what about (humanoid) robots, i.e., non-human entities? (see, e.g., Brunschwig, "Humanoid robots for contract visualisation," 142-60). While I recognize the need for theorizing, to firmly undergird legal design, I wonder whether we first need to outline legal design more concretely. Presumably, different theories will become viable depending on how the field is delineated, especially within the scientific community.

13 Krawietz, Owoyele, and Edelman, 54

14 Hagan, "Legal Design as a Thing," 3.

15 Hagan, "Legal Design as a Thing," 3.

16 Hagan, "Legal Design as a Thing," 3.

7 Hagan, "Legal Design as a Thing," 4.

18 Hagan, "Legal Design as a Thing," 14. Compare Santuber, Krawietz, Owoyele, and Edelman, 45.

19 Hagan seems to mean what is designed (e.g., legal visuals, legal audiovisuals, legal robots, and legal virtual realities).

20 Hagan, "Legal Design as a Thing," 4. 
contracts, ${ }^{21}$ access to justice, ${ }^{22}$ dispute prevention and resolution, ${ }^{23}$ e-government, ${ }^{24}$ legal education, ${ }^{25}$ and data protection. ${ }^{26}$ Yet we still lack legal scholarship on the relations between visual law and legal design (i.e., their similarities and differences). The few existing studies fail to clearly distinguish these areas. ${ }^{27}$ This is, of course, barely astonishing at this nascent stage of research.

Third, I approach the idea of responsible digitalization etymologically. The adjective "responsible" originates from Latin respondere, that is, to answer (respond) and correspond to something. ${ }^{28}$ Responsible, then, implies a quality that is required of digitalization.

Based on these three premises, I ask four key questions:

- How does legal research respond to visualization?

- What are visual law and legal design?

- How are visual law and legal design similar or different?

- How might visual lawyers or legal designers act responsibly in the face of ongoing digitalization?

I approach these questions against the background of the basic legal disciplines and law-and areas. I do not, however, focus on any specific legal systems or jurisdictions.

\section{Legal Visualization: A Working Definition}

As my working definition of "visualization" (i.e., "legal visualization) is rather abstract, let me illustrate its key elements with a miniature from of the Heidelberg Illustrated Manuscript of the Saxon Mirror folio 28 recto 3 (early $14^{\text {th }}$ century; see Figure 1 ).

21 See, e.g., Haapio, "Making Contracts Work for Clients," 389, 391-94; Passera and Haapio, "Transforming Contracts from Legal Rules to User-centered Communication Tools," 38, 40-44; Curtotti, Haapio, and Passera, "Interdisciplinary Cooperation in Legal Design and Communication," 455, 458-59; Haapio, Plewe, and de Rooy, "Next Generation Deal Design," 375, 378; Haapio and Hagan, "Design Patterns for Contracts," 381-82, 385-87.

22 For a general discussion, see Hagan, "A Human-Centered Design Approach to Access to Justice”; id., "The Justice is in the Details"; id., "Participatory Design for Innovation in Access to Justice"; Doherty, "Comprehensibility as a rule of law requirement"; Mik, "The Limits of Visual Law."

23 For a general discussion, see Solarte-Vasquez and Hietanen-Kunwald, "Responsibility and Responsiveness in the Design of Digital and Automated Dispute Resolution Processes."

24 For a general discussion, see Brunschwig, "Legal Design and e-Government."

25 For a general discussion, see Brunschwig, "Legal Design and Web Based Legal Training"; Jackson, "Human-centered legal tech."

26 For a general discussion, see Palmirani, Rossi, Martoni, and Hagan, "A Methodological Framework to Design a Machine-Readable Privacy Icon Set"; Rossi and Lenzini, "Making the Case for Evidence-based Standardization of Data Privacy and Data Protection Visual Indicators"; Rossi and Palmirani, "Can Visual Design Provide Legal Transparency?"

27 See, e.g., Frug, "Toward Inclusive Design for Visual Law," 1-3.

28 See, e.g., Hoad, The Concise Oxford Dictionary of English Etymology; Stowasser, Petschenig, and Skutsch, Der Kleine Stowasser, 397. 


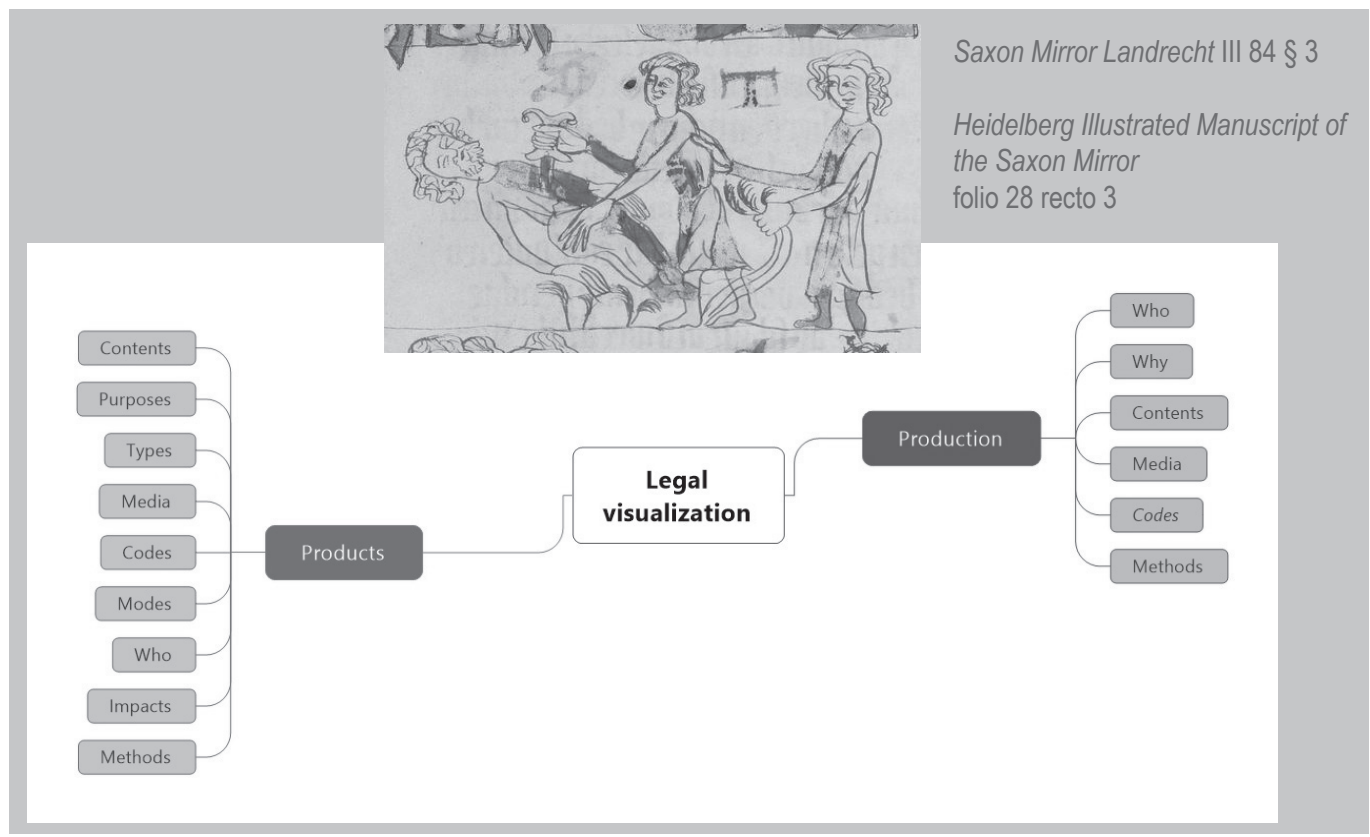

Figure 1

The mind map beside this illustration shows the core elements of my working definition. On the one hand, "legal visualization" denotes the visualization process (i.e., the production of visualizations; see the right branch of the mind map). On the other, "legal visualization" means the products of that process (see the left branch of the mind map).

From a legal perspective, the visualization process (i.e., producing visualizations) raises several basic questions: $^{29}$

- Who visualizes legal contents ${ }^{30}$ _legal professionals, law students, lay persons (e.g., illustrators, designers, computer scientists, or even humanoid robots)? Do these actors freely visualize the law or are they assigned this work? In the latter case, who assigns them? In our example, who illustrated the Heidelberg miniature? Was the illustrator commissioned?

- Why are legal contents visualized (reasons and purposes)? Why, for instance, was this miniature of the Saxon Mirror visually adorned, explained, and illustrated?

- What kinds of legal contents are visualized? Contents can be normative, descriptive, or both. Examples include enacted norms, sections of court orders and rulings, legal scholarship (research and teaching), state and private legal practice (e.g., contracts), legally relevant facts, and so on. In our example, Landrecht (Land Right) III 84 § 3 was visualized.

- Which media (analog, digital, or both, e.g., humanoid robots) are used to visualize legal contents? In our example, the illustrator probably used a quill (Federkiel) to draw the miniature and incorporated it on parchment (I have no details on the colors used).

\footnotetext{
29 Within the available scope, I limit myself to raising relevant questions (without necessarily providing answers). This also applies to questions about legal visualization as a product.

30 The expression "legal contents" also refers to matters related to law.
} 
- Which semiotic codes are chosen? Our example shows that the visual code was used to produce folio 28 recto 3 .

- Which visualization methods are applied? ${ }^{31}$ Our illustrator intuitively followed the methods of textual visualization. Today, these relate, among others, to visual rhetoric, ${ }^{32}$ graphic design, and information design. In our example, the ears (Ähren) are a pars pro toto for the property to be inherited from the man being slain in the image. The illustrator used two methods to visualize these ears: pars-to-toto synechdoche and symbolization. The ears, as the partes of the victim's estate and as symbols of his estate.

As products, legal visualizations also raise various basic questions:

- Which legal contents appear in verbo-visual or visual form?-In our example, the Heidelberg Illustrated Manuscript of the Saxon Mirror folio 28 recto 3 visualizes Landrecht III $84 \S 3$. The Heidelberg Illustrated Manuscript of the Saxon Mirror visualizes the contents of territorial or rural law (Landrecht) and feudal law (Lehnrecht). ${ }^{33}$

- What are the purposes of legal visualizations? - In essence, the miniatures of the Illustrated Manuscripts of the Saxon Mirror serve to illustrate, explain, and adorn the visualized legal text. ${ }^{34}$ This also applies to the present example.

- How can we categorize legal visualizations? One's answer depends on one's categorization criteria: e.g., image types, visualized contents, purposes of legal visualizations, the types of media used. With the Illustrated Manuscripts of the Saxon Mirror, it makes sense to categorize the miniatures according to the visualized legal contents. "In the Saxon Mirror, one searches in vain for categorizations and systematizations that are common in modern law." 35 Roughly speaking, the miniatures of the Heidelberg Illustrated Manuscript of the Saxon Mirror include either rural law or feudal law.

- In which media do legal visualizations or verbo-visualizations appear (mediality)? -Essentially, the media are analog (e.g., paper, parchment) or digital (e.g., computer screens). Thus, the Heidelberg Illustrated Manuscript of the Saxon Mirror folio 28 recto 3 now manifests in three media: parchment (original version), facsimile (on paper), and digital media (e.g., computer screens).

- How do legal visualizations or verbo-visualizations manifest semiotically (codality)? - They materialize in two codes: visual and verbo-visual. So does our example.

- Which perceptual mode do visualizations or verbo-visualizations appeal to, or which mode are they capable of (e.g., a camera connected to visualizations that records recipient interaction. Thus, the device is capable of "sight.") (modality)?-Legal visualizations, such as the Heidelberg Illustrated Manuscript of the Saxon Mirror folio 28 recto 3, appeal to the sense of sight.

- Whom are legal visualizations addressed to? - Several renowned princes (Fürsten) are said to have commissioned the Illustrated Manuscripts of the Saxon Mirror. ${ }^{36}$ The manuscripts even bear traces of their usage ${ }^{37}$ However, it seems unclear who the actual addressees were. That aside, and with today in mind, contemporary legal visualizations address both legal actors (e.g., lawyers, law students, judges, prosecutors) and laypersons.

31 I am adapting and sharpening questions that I have raised elsewhere (see, e.g., Brunschwig, "Perspectives of Digital Law," marginal numbers 4-6).

32 See, e.g., Brunschwig, Visualisierung von Rechtsnormen, 86-93. On visual rhetoric, see, e.g., Chandler and Munday, A Dictionary of Media and Communication.

33 See Repgow, The Saxon Mirror, 6-7.

34 See, e.g., Lück, Der Sachsenspiegel, 90.

35 "Die im modernen Recht üblichen Kategorisierungen und Systematisierungen des Rechts sucht man natürlich vergeblich; [...]." (Kocher, "Das Landrecht des Sachsenspiegels," 63). Similarly, see, e.g., Lück, 53.

36 See, e.g., Lück, 51.

37 Kocher, "Die Stellung der Heidelberger Bilderhandschrift innerhalb der Codices picturati," 22. 
- How do legal visualizations or verbo-visualizations affect their addressees? How do they experience visualizations? How do they behave toward them? With which attitude? - Not knowing their addressees, we are unable to establish the impact of the Illustrated Manuscripts of the Saxon Mirror. Regarding modern legal visualizations, this question might best be answered based on empirical research.

- Which methods help to describe, analyze (interpret), and evaluate legal visualizations and verbo-visualizations?-As a rule, the methods of legal interpretation apply only to texts, such as rules and contracts, last wills (i.e., verbocentric legal hermeneutics). Different types of legal visualizations call for distinct methods of interpretation and evaluation. In our example, I use the (legal) iconographical method to describe and interpret folio 28 recto 3 (see 4.2.1.).

\section{Response of Legal Scholarship to Visualization}

\subsection{Response of doctrinal legal scholarship to visualization}

Legal scholars do various kinds of research. ${ }^{38}$ Among these, doctrinal research is the most important. As a rule, doctrinal legal scholarship starts from controversies over facts ("factual elements" 39 ), from normative problems ("legal elements" ${ }^{40}$ ), or from other subjects. ${ }^{41}$ As Epstein observes: "There is much to dispute in all the areas of law that are part of the modern landscape, including environmental law, antidiscrimination law, antitrust and trade regulation, pensions, taxation, and family law. Each area raises distinctive questions $[\ldots] . " 42$

Doctrinal legal scholarship analyzes, systematizes, and critically examines positive law (its development and status quo, concepts, principles). ${ }^{43}$ It acts or proceeds like this in case law (e.g., court, administrative, and governmental practice). ${ }^{44}$ Cases are either real or hypothetical. Further, doctrinal legal scholarship analyzes, systematizes, and critiques other doctrinal legal scholarship (published, for instance, in monographs, collected volumes, and journals). Doctrinal legal scholarship reconceptualizes law by proposing new legislation..$^{45}$ Occasionally, it even drafts new legislation. As a rule, legal scholars, be they academics, practitioners, or legislative actors, neither draw on nor integrate the insights of the humanities, social sciences, and other university disciplines into their research. ${ }^{46}$

Doctrinal legal scholarship intersects with visualization in examining how, for instance, trial lawyers paint mental pictures with words. It also explores how such lawyers use visual metaphors to advance their client's cause before civil, criminal, or other courts. ${ }^{47}$ Especially US-American legal scholarship deals with these issues because juries - consisting of laypersons — need to be persuaded with words and pictures, whether mental or material. ${ }^{48}$

\footnotetext{
See, e.g., Barkan, Bintliff, and Whisner, Fundamentals of Legal Research, 15.

Barkan, Bintliff, and Whisner, 24.

Barkan, Bintliff, and Whisner, 24.

See, e.g., Barkan, Bintliff, and Whisner, 15, 19.

Epstein, "Let 'The Fundamental Things Apply," 1313.

See, e.g., Epstein, 1288, 1290; see further Barkan, Bintliff, and Whisner, 16-17; Posner, "Legal Scholarship Today,” 1316.

See, e.g., Posner, 1315-16.

See, e.g., Posner, 1314.

See, e.g., Posner, 1315-16.

47 On law and metaphors, see Hibbitts, "Making Sense of Metaphors"; Kleinhietpaß, Metaphern der Rechtssprache und ihre Verwendung für Visualisierungen.

48 See, e.g., Grimm, Petrosinelli, and Faust, "Tips for Daubert Motions from a Judge, an Attorney, and a Behavioral Scientist,” 1007.
} 


\section{VISUALIZATION}

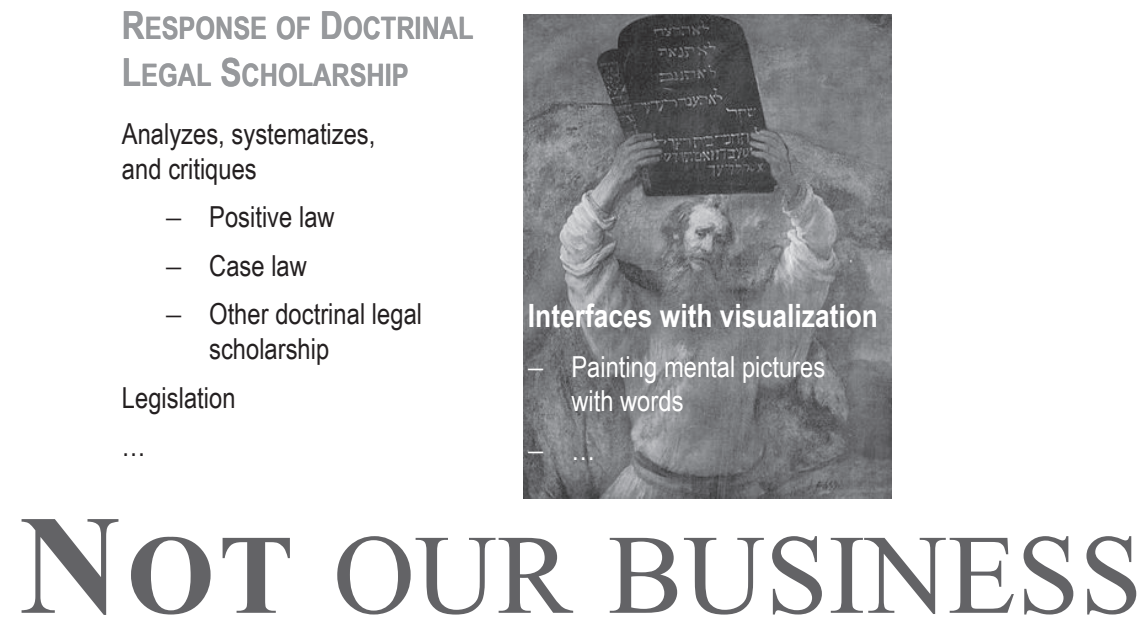

Figure $2^{49}$

Otherwise, however, visualization does not seem to be part of doctrinal legal scholarship. Mulcahy confirms this: "the complex interface between law and visual culture continues to be a marginal aspect of legal scholarship." ${ }^{50}$ Visualization therefore raises several meta-questions: What is and what is not legal scholarship? What is its mission? "[H] $[\mathrm{H}]$ ow do we identify a fit subject for legal inquiry?"52 Is visualization really fit for legal inquiry?

\subsection{Response of interdisciplinary legal scholarship to visualization}

Epstein finds that "legal scholarship cannot be confined to housekeeping duties." 53 Thus, its agenda cannot be limited to doctrinal legal scholarship but also encompasses (or needs to encompass) interdisciplinary legal scholarship. Such work transcends disciplinary boundaries by drawing on "techniques, vocabulary, and insights from other fields." ${ }^{54}$ Visual research requires interdisciplinary scholarship. Both the basic legal disciplines and law-and areas conduct visual research.

The basic legal disciplines include visual legal-historical studies. These are oriented toward visual historical studies and art history (iconography studies, a branch of art history, serves as a model for legal iconography). These disciplines also include visual legal theory (visual jurisprudence) and visual sociology of law (which leans on visual sociology). ${ }^{55}$ It is beyond my present scope to consider other basic legal disciplines (or their

\footnotetext{
49 In Figure 2, I have embedded Rembrandt Harmenszoon van Rijn's "Moses Breaking the Tablets of the Law" (1659): https:/ en.wikipedia.org/wiki/Moses_Breaking_the_Tablets_of_the_Law (last accessed November 30, 2020). This image is available in the public domain.

50 Mulcahy, "Eyes of the Law," S117.

51 See, e.g., Rhode, "Legal Scholarship," 1330.

52 Torres, "Translation and Stories," 1362.

Epstein, 1289.

54 Posner, 1321. Similarly, see, e.g., Rakoff, "Introduction,” 1280.

55 On visual sociology, see, e.g., Harper, "Visual Sociology," 54-55, 60-61, 67; Burri, "Visual rationalities," 45-48, 54-55; Harper, Visual Sociology, 4.
} 
branches) that deal with visualization (e.g., visual legal pedagogy ${ }^{56}$ visual legal informatics ${ }^{57}$ visual philosophy of $\mathrm{law}^{58}$ ).

The law-and areas involve, for example, law-and visual art, law-and visual persuasion, law-and visual culture, law-and sight, and law-and graphic design.

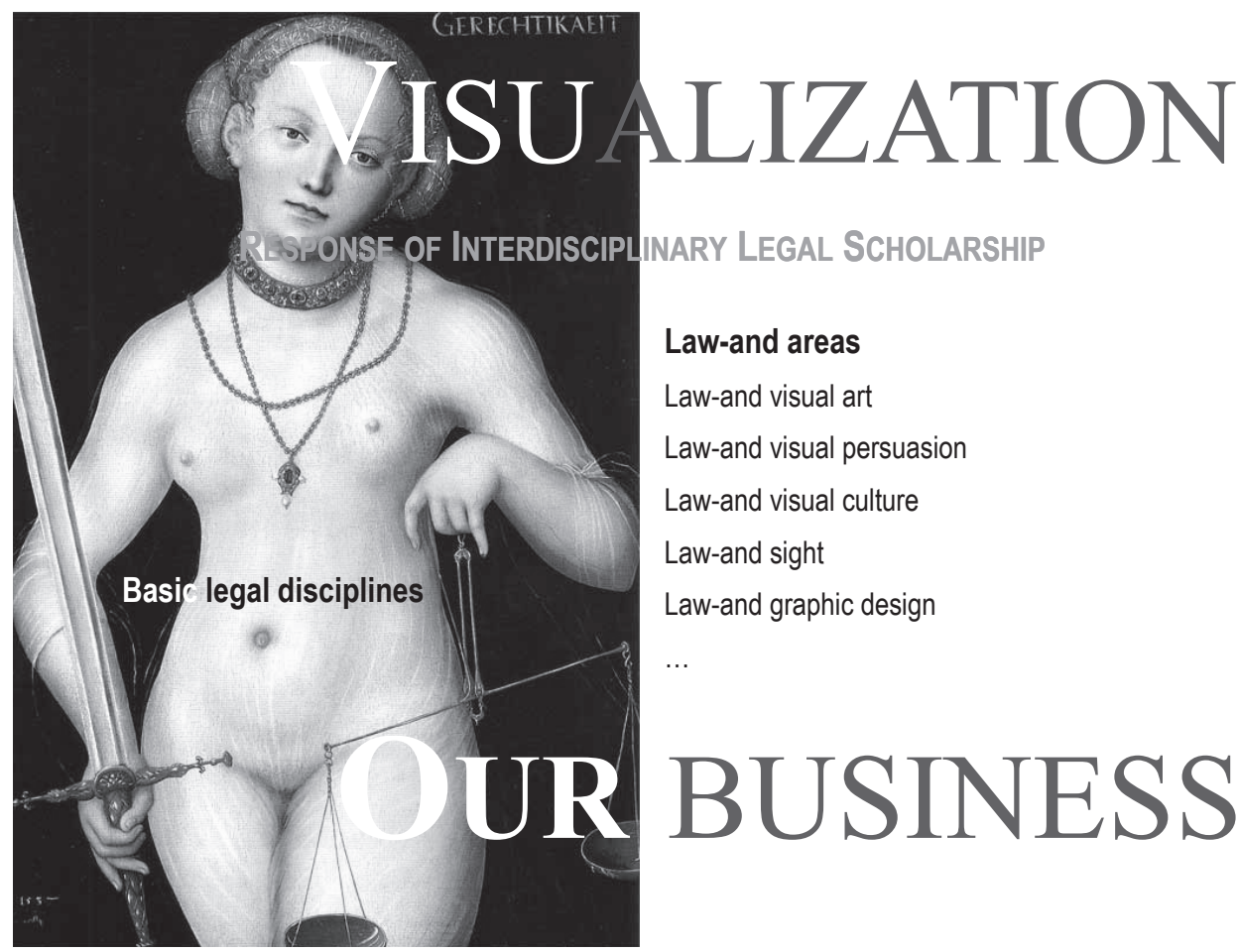

Figure $3^{59}$

Generally, these fields consider legal visualization "from the outside, from perspectives shaped by other fields of inquiry, $[\ldots] ., 60$

56 For a survey of the numerous publications on visual legal education, see, e.g., Brunschwig, "Humanoid Robots in Legal Education," $279-80$, footnote 83 .

57 The papers published by the journal "Visual Informatics" offer a glimpse of the subject matter of visual legal informatics and might stimulate pertinent research in the field of legal informatics (see Visual Informatics, https://www.sciencedirect.com/journal/visualinformatics (last accessed November 30, 2020)). The technical contents of these contributions raises the question to what extent they should be considered by legal informatics. I posit that "visual" legal informatics originates in the representation of visual legal knowledge (see, e.g., with further references, Brunschwig, "Multisensory Law and Legal Informatics," marginal notes 166-170).

58 Some philosophers are already speaking of "visual philosophy" (see, e.g., Zhao and Zhang, "Development of Visual Philosophy under Impact of Philosophy of Technology"). The discourse on the ethical dimensions of visualization concerns visual philosophy (on these dimensions, see, e.g., Sheppard, "Validity, reliability, and ethics in visualization"). I could imagine that a (as yet nonexistent) visual philosophy of law could engage in debating the ethics of legal visualization. My "Visual Lawyers, Legal Designers, and Responsible Digitalization" (see below 7. and 8.4.) contributes to that debate. On "Ethics and Justice in the Digital Visual Age," see Feigenson and Spiesel, 195-221. In addition to the ethics of legal visualization, its aesthetics and rhetoric are further important concerns of a visual philosophy of law.

59 In Figure 3, I have embedded Lucas Cranach's The Elder's "Justice as a Naked Woman with Sword and Scales" (1537): https:// de.wikipedia.org/wiki/Datei:Gerechtigkeit-1537.jpg (last accessed November 30, 2020). This image is available in the public domain.

60 Posner, 1316. 


\section{Visual Law}

\subsection{Subject matter}

Defining and thus delimiting a research area requires identifying its subject matter and deciding how to establish subareas. Two paths seem feasible with regard to subject matter: First, to establish key concepts. ${ }^{61}$ Second, to identify prototypical situations and establish characteristic components. ${ }^{62}$

In this paper, I have already taken both paths: First, I have mind mapped "legal visualization" as a key concept of visual law (see above 2.). To repeat the key point: "Legal visualization" is both process and product. Legal visualization as a product is a mode of communication that relates to legal or legally relevant contents. Second, my mind map shows the prototypical situation of legal visualization and its characteristic components. Figure 4 also presents another visualization of the prototypical situation and its characteristic components: actors, processes, contexts, products.

\section{VISUAL LAW}

Subject matter

- Key concept

- Prototypical situation
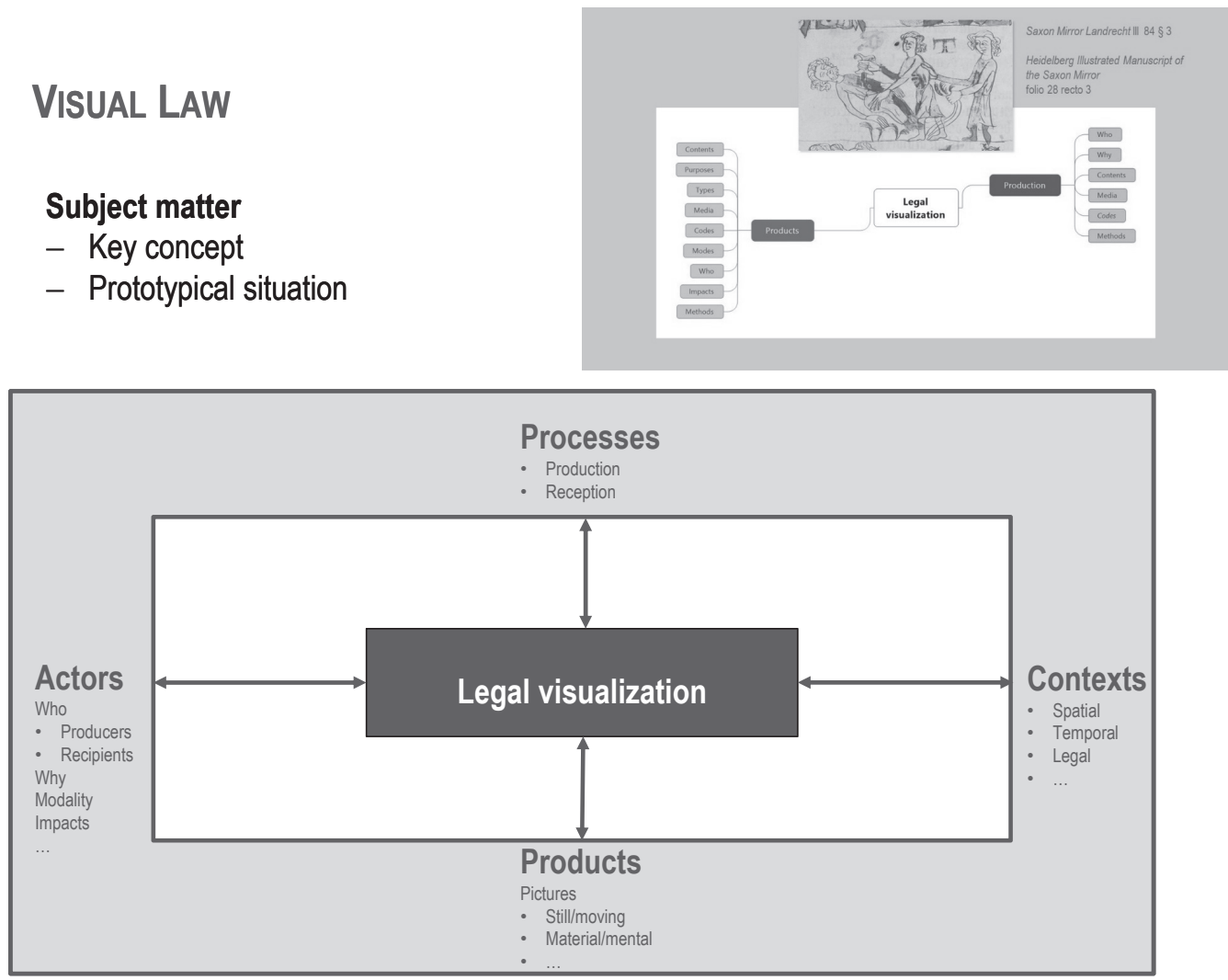

Figure 4

61 See, e.g., Krapp, Prenzel, and Weidenmann, "Geschichte, Gegenstandsbereich und Aufgaben der Pädagogischen Psychologie,” $20-24$. I have transposed these authors' reflections to outline visual law.

62 See Krapp, Prenzel, and Weidenmann, 24-27. I have transposed these authors' reflections to outline visual law. 


\subsection{Subareas}

Figure 5 (see below), though not exhaustive, suggests how visual law might be divided into subareas. Visual law, I posit, chiefly includes the interdisciplinary research of the basic legal disciplines and the law-and areas. The former include visual legal-historical studies, visual jurisprudence (visual legal theory), the visual sociology of law (as practiced by legal scholars and by sociologists), and so forth. Among others, the latter comprise law-and visual art, law-and visual persuasion (including visual evidence and visual argumentation), law-and visual culture, law-and sight (an approach common within law-and the senses), law-and graphic design (common in legal design). These subareas have special subject matters, which are related to the subject matter of visual law (see Figure 4).

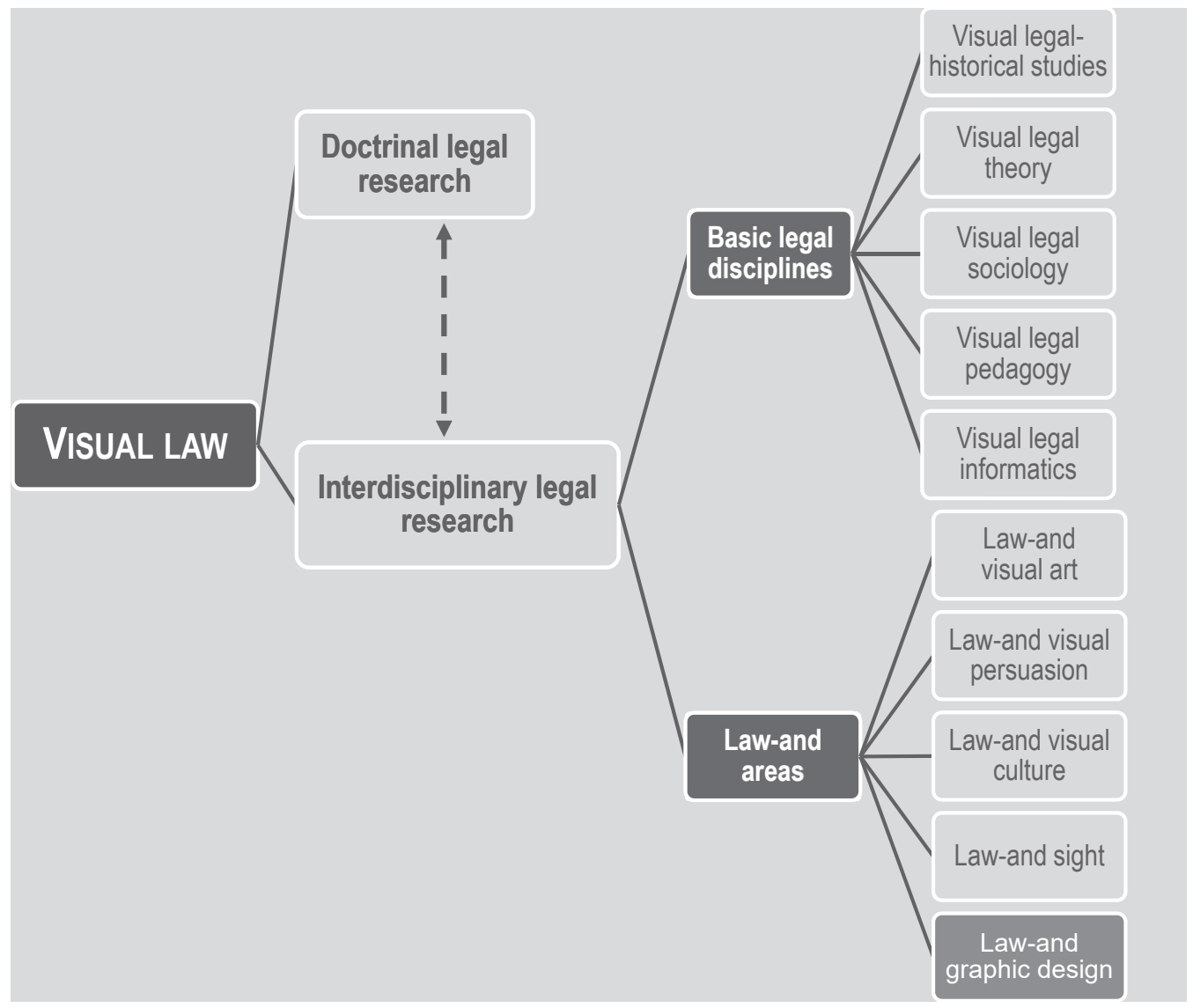

Figure 5 


\subsubsection{Basic legal disciplines}

\subsubsection{Visual legal-historical studies and visual historical studies Visual historical studies}

Before outlining visual legal-historical science, I consider two visual approaches in or subareas of historical science: historical image research (historische Bildforschung) and visual historical studies (visuelle Geschichtswissenschaft). Legal-historical science as a rule adopts insights from historical science, a significant neighboring discipline. ${ }^{63}$ Hence, it cannot afford to disregard historical image research and visual historical studies.

Historical science assumes that history also manifests visually and investigates how images relate to history. Under the label "historische Bildforschung," ${ }^{64}$ German-speaking historical science explores this relationship from various perspectives and studies diverse topics, including "pictorial material as sources of historical facts and circumstances" ${ }^{\prime 65}$ and the "critical evaluation of image sources." ${ }^{\prime 66}$ Such source criticism collects visual sources, ${ }^{67}$ determines their theme(s) ${ }^{68}$ and classifies them. ${ }^{69}$ In doing so, historical image research considers in which spatial, temporal, social, economic, political, legal, technical, and cultural contexts these images emerged. Historical image research also explores textual sources, which describe and analyze how images relate to history. ${ }^{70}$ Adopting approaches from historical science and art history, this research area understands "works of art and visual works in general as bearing witness to a historical era [...] and attempts to derive knowledge from them about the past." 71

Modern recent history and contemporary history have been transcending historical image research by setting forth visual history ${ }^{72}$ or rather visual historical studies. ${ }^{73}$ This field reflects on "images in a broad sense both as sources and as independent objects of historiographic research." "74 Visual historical studies examine the "visuality of history" and the "historicity of the visual." 75 The ongoing large-scale expansion of visual media and their contents, especially moving images (e.g., visual animations, video and film images), has initiated the transition from historical image research to visual historical studies. The former predominantly focuses on medieval and early modern visual sources ${ }^{76}$ (e.g., paintings and printed graphics, ${ }^{77}$ drawings, reliefs, etc.). These works are still (i.e. unmoving) images. ${ }^{78}$ Visual historical studies, however, investigate the entire spectrum of visual sources. ${ }^{79}$ This also includes moving images ${ }^{80}$-regardless of whether these are works of art, or what Elkins calls

63 See, e.g., Kocher, Zeichen und Symbole des Rechts, 7.

64 Other terms include historische Bildwissenschaft or historische Bildkunde ["historical image science"] (see, e.g., Wimböck, "Historische Bildforschung," 175).

65 Original citation: "Bildmaterial als Quellen für historische Sachverhalte" (Wimböck, 176).

66 Original citation: "kritische Bewertung der Bildquellen" (Wimböck, 176).

67 See, e.g., Wimböck, 176-77.

68 See, e.g., Wimböck, 177.

69 See, e.g., Wimböck, 177.

70 See, e.g., Wimböck, 176. See also Perlmutter, "Visual Historical Methods," 173. Both authors are referring to visual historical science (see below).

71 Original citation: "Kunst- und Bildwerke allgemein vorrangig als Zeugnisse einer Geschichtsepoche [...] und versucht, aus ihnen Kenntnisse über die Vergangenheit zu gewinnen" (Wimböck, 175). Originally, historical image science concentrated mainly on images with artistic value (see, e.g., Wohlfeil, "Das Bild als Geschichtsquelle," 91 and 99).

72 Perlmutter, 167, 179-81.

73 Perlmutter also refers to "visual historical research" (Perlmutter, 168).

74 Original citation: "Bilder in einem weiten Sinne sowohl als Quellen als auch als eigenständige Gegenstände der historiografischen Forschung" (Paul, "Visual History," 2).

75 Original citation: "Visualität von Geschichte" and the "Historizität des Visuellen" (Paul, "Visual History," 2).

76 See, e.g., Paul, "Visual History," 4.

77 See, e.g., Paul, "Von der Historischen Bildkunde zur Visual History," 10.

78 See, e.g., Paul, "Visual History," 6.

79 See, e.g., Paul, "Visual History," 14.

80 See, e.g., Paul "Von der Historischen Bildkunde zur Visual History," 14, 18. 
"nonart images." ${ }^{81}$ Hence, visual historical studies suggest a "new" notion of what images are. ${ }^{82}$ This leads visual historians to inquire: "Are the images used in the research [on; my insertion] historical artifacts, or are they constructed by others and used as a way to view historical artifacts?" 83 Visual historical studies also focus on the mediality ${ }^{84}$ and communicative features ${ }^{85}$ of images. Investigating what images mean historically, ${ }^{86}$ visual historians consider content (e.g., persons, objects, animals, plants, space, time, and other contextual elements), form (perspective, composition, framing), and narrative elements (e.g., actions, conditions, processes). ${ }^{87}$ Visual historians thus aim to answer questions such as "What is the approach to the evidentiary value of the visual image? Is it analysed as a displayer of facts or purposeful construction of a particular viewpoint?"88 Other questions include: What was or is the historical purpose(s) of these visual sources? ${ }^{89}$ How do they refer to other images (interpictoriality)? How (and by whom) were these sources distributed ${ }^{90}$ and received ${ }^{91}$ How were they perceived $?^{92}$ How were they used $?^{93}$ And how do they not only represent but also construct realities? ${ }^{94}$

Visual historical studies also explore the (historical) impacts of visual sources,${ }^{95}$ as well as the digitalizing of these sources and their long-term archiving. ${ }^{96}$ In order to analyze and evaluate the historical meaning of visual sources, visual historical studies adopt a methodological pluralism, which includes iconographic and iconological methods, ${ }^{97}$ semiotic methods, ${ }^{98}$ and the methods of (visual) sociology. ${ }^{99}$ This pluralism seems to contrast with historical image research, which limits itself to the iconographic and iconological method. ${ }^{100}$ The questions and reflections of visual historical studies go beyond historical image research and include: "How does the setting of the presentation affect the image's presentation?" 101 Production-related questions include who created visual sources, who influenced their creation, ${ }^{102}$ how they were created, ${ }^{103}$ and in which contexts. ${ }^{104}$ Given the great variety of topics, visual historical studies rely on insights from various disciplines (e.g., art history, communication studies, media studies, (visual) sociology, semiotics, and Bildwissenschaft, i.e., image science). ${ }^{105}$ The growing significance of visual historical studies might lead to a new research direction within legal-historical studies: visual legal-historical studies (see next section).

\footnotetext{
1 Elkins, The Domain of Images, 5-11.

See, e.g., Paul "Von der Historischen Bildkunde zur Visual History,"11.

Perlmutter, 179; original italics.

4 See, e.g., Paul "Von der Historischen Bildkunde zur Visual History," 13, 16-18; id., "Visual History," 8.

See, e.g., Paul, "Visual History," 8.

See, e.g., Perlmutter, 169-70.

7 For details, see, e.g., Perlmutter, 169, 173-74, 179.

Perlmutter, 179; original italics.

See, e.g., Perlmutter, 167, 169.

See, e.g., Paul, "Visual History," 15; Perlmutter, 167, 171.

See, e.g., Paul, "Visual History," 4, 15; Perlmutter, 170, 172.

See, e.g., Paul "Von der Historischen Bildkunde zur Visual History," 11, 14, 19, 25; id., "Visual History," 11; Perlmutter, 181.

3 See, e.g., Paul "Von der Historischen Bildkunde zur Visual History," 14; id., "Visual History," 4; Perlmutter, 170.

4 See, e.g., Paul, "Visual History," 11.

95 See, e.g., Paul "Von der Historischen Bildkunde zur Visual History," 9, 12, 18, 20, 28; id., "Visual History," 4, 8, 10, 12-14; Perlmutter, 167.

96 See Bauer, "Analoge Fotografie im digitalen Zeitalter"; Bove and Schmahl, "Fotografische Nachlässe"; Melone, "KommerzGeschichte"; Pfeiffer, "Wie können Bildbestände bewertet werden?"

97 See, e.g., Paul "Von der Historischen Bildkunde zur Visual History," 24; id., "Visual History," 5-6.

98 See, e.g., Paul "Von der Historischen Bildkunde zur Visual History," 24; id., "Visual History," 4-6.

99 See, e.g., Paul "Von der Historischen Bildkunde zur Visual History," 24; id., "Visual History," 5-6.

100 See, e.g., Paul "Von der Historischen Bildkunde zur Visual History," 10. Regarding the focus of historical image science on the iconographic and iconological method, see, e.g., Gräf, "Historische Bildkunde," 391-92.

101 Perlmutter, 173.

102 See, e.g., Perlmutter, 167-68.

103 See, e.g., Perlmutter, 171.

104 See, e.g., Perlmutter, 167, 171.

105 See, e.g., Paul "Von der Historischen Bildkunde zur Visual History," 26-27.
} 


\section{Visual legal-historical studies}

The legal past has handed down various kinds of sources, including images and texts. Although legal-historical studies examine the relations between legal history and images, ${ }^{106}$ they mainly focus on verbal sources and hence consider legal-historical images to be secondary sources. ${ }^{107}$ These "secondary" sources visualize past law. ${ }^{108}$ Two branches of legal-historical studies in particular explore the relationship between images and legal history: (historical) legal iconography and legal iconology. German-speaking Rechtsikonographie (legal iconography) emerged in 1989. ${ }^{109}$ Legal iconographers speak of "Rechtsikonographie," implying that this field also involves iconological issues. To simplify matters, I will do so, too, although I usually distinguish legal iconography and legal iconology. ${ }^{110}$ Legal iconography has an intradisciplinary and an interdisciplinary orientation. It draws on legal archaeology (Rechtsarchäologie), ${ }^{111}$ legal folklore (Rechtliche Volkskunde), ${ }^{112}$ and legal symbolics (Rechtssymbolik), ${ }^{113}$ as well as art studies ${ }^{114}$ and the historical sciences. In Germanspeaking scholarship, the book series signa iuris promotes legal-iconographical and legal-iconological research. ${ }^{115}$ The key issues of (German-speaking) legal iconography include establishing what legal images are ${ }^{116}$ which criteria might serve to classify such images, ${ }^{117}$ and how they might be delimited from non-legal images. ${ }^{118}$ Legal iconography studies the purposes of visual sources (functional approach), ${ }^{119}$ as well as creates and makes accessible collections of analog and digital legal images. Legal iconography contributes to curating image collections and plays a significant part in scientifically supporting and evaluating legal image databases. ${ }^{120}$

The term "legal iconography" not only denotes a legal-historical subdiscipline. It also means to methodically describe and interpret legal images (iconographic approach), ${ }^{121}$ as well as to understand such images in

106 See, e.g., Fehr, Das Recht im Bilde; Pleister and Schild, Recht und Gerechtigkeit im Spiegel der europäischen Kunst; Köbler, Bilder aus der deutschen Rechtsgeschichte; Manchester and Becker-Moelands, "An Introduction to Iconographical Studies of Legal History"; Kocher, Zeichen und Symbole des Rechts; Schild, Bilder von Recht und Gerechtigkeit; Douzinas and Nead, Law and the Image; Widener and Weiner, Law's Picture Books.

107 See, e.g., Kocher, Zeichen und Symbole des Rechts, 7. Elsewhere, Kocher doubts whether visual sources constitute secondary sources (see id., "Bilder," 228; see also Legat, Bildquellen als Informationsträger in der Rechtsgeschichte).

108 See, e.g., Kocher, Zeichen und Symbole des Rechts, 8.

109 See, e.g., Kocher, "Bilder," 224.

110 See Brunschwig, Visualisierung von Rechtsnormen, 11-18.

111 See, e.g., Kocher, Zeichen und Symbole des Rechts, 11, 13.

112 See, e.g., Kocher, Zeichen und Symbole des Rechts, 11, 13.

113 See, e.g., Kocher, Zeichen und Symbole des Rechts, 13; id., "Die Rechtsikonographie," 224.

114 See, e.g., Kocher Zeichen und Symbole des Rechts, 11.

115 See Peter Junkermann Verlag, "SIGNA IURIS."

116 See, e.g., Kocher, Zeichen und Symbole des Rechts, 12; Brunschwig, Visualisierung von Rechtsnormen, 116-18.

117 See, e.g., Kocher, Zeichen und Symbole des Rechts, 10-12; Brunschwig, Visualisierung von Rechtsnormen, 118-21.

118 See, e.g., Brunschwig, Visualisierung von Rechtsnormen, 121.

119 See, e.g., Kocher, Zeichen und Symbole des Rechts, 7-8; Brunschwig, Visualisierung von Rechtsnormen, 16-18.

120 See, e.g., Laufs, "Die Fehrsche rechtsarchäologische Bildersammlung"; Becker-Moelands, "Die Erschliessung der ikonographischen Sammlung des Niederländischen Zentrums für rechtshistorische Dokumentation”; Brunschwig, "Die Forschungsstelle für Rechtsgeschichte im Spiegel alter und neuer Medien," 68-72; Schmoeckel, "Karl von Amira und die Anfänge der Rechtsarchäologie"; Dölemeyer, "Dinge als Zeichen alten Rechts"; Widener and Weiner, 1-8; Prinz, Der Bildgebrauch in gedruckten Rechtsbüchern des 15. bis zum Ausgang des 18. Jahrhunderts, 25-29. See also the relevant websites: Bayerische Staatsbibliothek, Die rechtsarchäologische Sammlung Karls von Amira 1848-1930, https://amira.digitale-sammlungen.de/projekt/projekt.php (last accessed November 30, 2020); Max-Planck-Institut für Europäische Rechtsgeschichte, Rechtsikonographie und Rechtsarchäologie: Die Bildersammlung Karl Frölich, http://sfr.rg.mpg.de/ (last accessed July 14, 2020); Karl-Franzens-Universität Graz, Institut für Rechtswissenschaftliche Grundlagen, Gernot Kocher, https:/gams.uni-graz.at/context:rehi (last accessed November 30, 2020); University of Zurich, Centre for Legal-historical Research, Legal Image Database, https:/www.ius.uzh.ch/en/research/units/zrf/ abtrv/bilddatenbank.html (last accessed November 30, 2020; database currently under review); Max-Planck-Institut, Kunsthistorisches Institut in Florenz, Costanza Caraffa and Carolin Behrmann, The Nomos of the Law: Manifestations of the Law in Picture Atlases and Photo Archives, http://photothek.khi.fi.it/documents/oau/00000250?Language=en (last accessed November 30, 2020).

121 See, e.g., Kocher, Zeichen und Symbole des Rechts, 12-14; id., "Die Rechtsikonographie," 108, 117; Brunschwig, Visualisierung von Rechtsnormen, 11-16. 
terms of the legal, religious, social, and other contexts from which these visual sources emerged (iconological approach). ${ }^{122}$ The iconographical approach aims to determine the legal content and, if required, the deeper legal meaning of visual sources. In illustrating the iconographic approach, I follow van Straten's multi-phase procedure. ${ }^{123}$ This approach differs from Kocher's: In order to deduce an "overall legal message"124 from visual sources, the Austrian legal iconographer suggests "squeezing" the multi-phase procedure into a single phase. Yet this approach risks confounding the three iconographical phases and the iconological phase, and thereby neglecting important aspects of iconographic or iconological analysis.

Figure 6 shows folio 28 of the Heidelberg Illustrated Manuscript of the Saxon Mirror. I have highlighted the third row of the miniatures (see rectangle) and raise three questions: What does this miniature show (first phase, pre-iconographical description)? What is its legal subject matter (second phase, iconographical description)? Does it or do some of its elements have a deeper legal meaning (third phase, iconographical interpretation)?

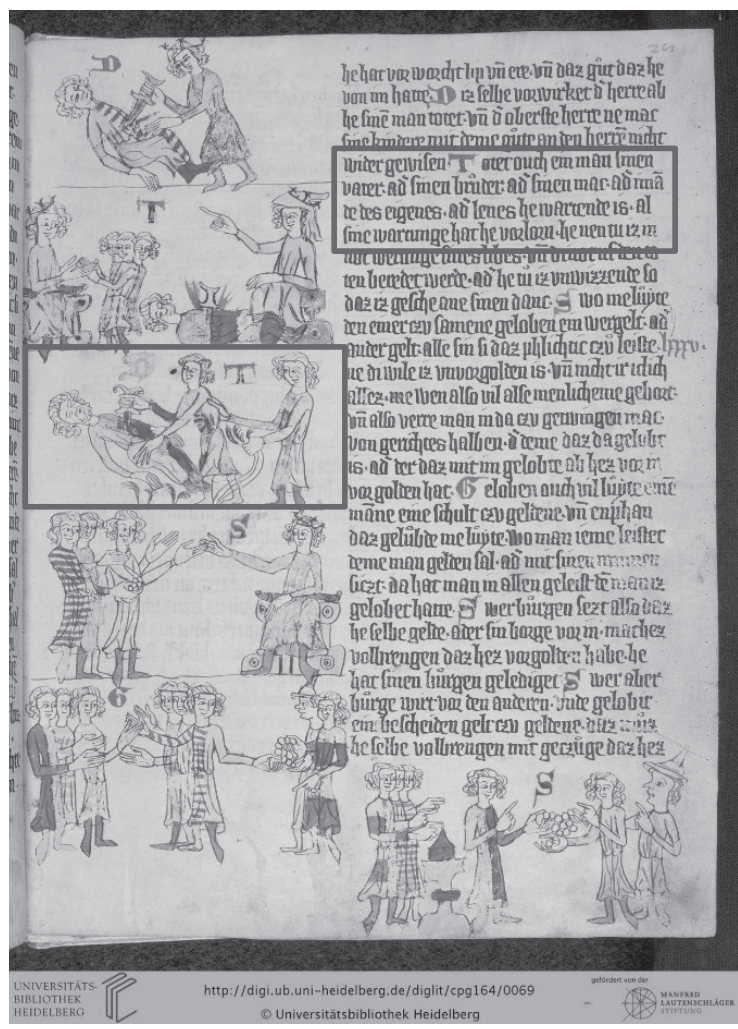

\section{VISUAL LEGAL-HISTORICAL STUDIES (LEGAL) ICONOGRAPHY}

Saxon Mirror Landrecht III 84 § 3

Heidelberg Illustrated Manuscript of the Saxon Mirror

folio 28 recto 3

Figure 6

We see three men. The first man has a beard and is falling on his back. With his right hand, the man in the middle stabs the bearded man to death, while his left hand reaches out to clutch some ears (Ähren). Both men

\footnotetext{
122 See, e.g., Brunschwig, Visualisierung von Rechtsnormen, 14; Behrmann, "The Mirror Axiom," 52; Martyn and Huygebaert, "Twenty New Contributions to the Upcoming Field of Historical Legal Iconology," 6.

123 See van Straten, An Introduction to Iconography, 3-12.

124 Original citation: "rechtlichen Gesamtaussage" (Kocher, Zeichen und Symbole des Rechts, 12; id., "Die Rechtsikonographie,” 117).
} 
are wearing similarly colored clothes. The third man on the right grabs the ears while touching or pushing away the man in the middle.

The illustration gives Landrecht III $83 \S 3$ as its textual source: "Totet ouch ein man sinen vater. Ader sinen bruoder. Ader sinen mac ader immman de des eigenes. Ader lenes wartende is. Al sine wartunge hat he vorlorn. [...]." "If a man kills his father, his brother, his kinsman, or someone belonging to the allod [fully owned estate] or fief [feudum] for which he is awaiting, he voids his grant in expectancy totally. [...] [insertions added]." 125 The respective miniature transcodes this text, while specifying it with a concrete case.

Both the left man's beard and the ears have a symbolic meaning. The beard denotes that an older man is represented, i.e., the father of the young man in the middle. The ears stand as a pars pro toto for the property to be inherited. The facts of the case are that a son kills his father. The legal consequence is that since the son's action disqualifies him as a heir under applicable law (Landrecht), the third man (on the right) is entitled to the estate. His seizing of the ears symbolizes this entitlement.

Against this background (i.e., legal history's relationship with images in the form of legal iconography), how does the latter relate to historical image research (historische Bildforschung) and visual historical studies (visuelle Geschichtswissenschaft)? By considering iconological issues, legal iconography might move in a direction similar to historical image research. But legal iconography is not (yet) systematically and critically examining how textual sources grapple with visual legal-historical sources. Nor has this field begun embracing the insights of visual historical studies. This makes it difficult to recognize what might be called visual legal-historical studies. What does this mean? Well, despite the large-scale expansion of visual media and their contents since the late $20^{\text {th }}$ century, (German-speaking) legal iconography has not expanded its traditional concept of legal images. Thus, it neither covers the entire range of visual legal-historical sources nor has it considered whether it ought - mutatis mutandis - to follow visual historical studies. Its methodological spectrum remains limited, as the field has so far not drawn on the insights of communication studies, media studies, image science, and other disciplines. Take, for example, legal elements in visual sources. Kocher has suggested four categories of elements: persons, ${ }^{126}$ realia (e.g., movable and immovable corporal things, animals, plants), ${ }^{127}$ gestures, ${ }^{128}$ as well as external and internal image texts. ${ }^{129}$ A glance at visual historical studies suggests that this classification needs to be refined. In terms of images (Abbilder), I therefore propose the following classification:

- Persons:

- Status

- Legal $^{130}$

- Social $^{131}$

- Economic

- Legal relationship with

- (Corporal) things ${ }^{132}$

- Persons ${ }^{133}$

- Movable and immovable things

- Animals

125 Repgow, 138. I am aware that the current translation actually refers to the Wolfenbüttel Illustrated Manuscript of the Saxon Mirror. I am using this translation as it fits this passage of the Heidelberg Illustrated Manuscript of the Saxon Mirror quite well.

126 See Kocher, Zeichen und Symbole des Rechts, 36-37; id., "Die Rechtsikonographie," 108, 110, 113-16.

127 See Kocher, Zeichen und Symbole des Rechts, 38-39; id., "Die Rechtsikonographie," 108, 110, 117.

128 See Kocher, Zeichen und Symbole des Rechts, 37-38; id., "Die Rechtsikonographie," 108, 110, 116.

129 See Kocher, Zeichen und Symbole des Rechts, 39-40; id., "Die Rechtsikonographie," 111-113.

130 See, e.g., Kocher, "Die Rechtsikonographie," 114.

131 See, e.g., Kocher, "Die Rechtsikonographie," 113-14.

132 See, e.g., Kocher, "Die Rechtsikonographie," 114.

133 See, e.g., Kocher, "Die Rechtsikonographie," 114. 
- Plants

- Contexts:

- spatial

- temporal

- legal

- religious

- social

- ...

- Narrative elements:

- Actions

- Conditions

- Processes

- Scenes

- Communication:

- Verbal

- Nonverbal (e.g., gestures, facial expressions, postures, body movements)

- Form (e.g., perspective, composition, framing, colors, ${ }^{134}$ light)

- Image text

- External (e.g., the image visualizes the external text)

- Internal.

Might these these categories also be applied to non-representational images (nicht darstellende Bilder)? As a rule, such images do not contain persons, corporal things, or narrative elements. Such images include charts (visualizations of qualitative relationships and processes), diagrams (visualizations of quantitative relationships), maps, abstract forms, e.g., some types of notary signets (Notarsignete). These types of images are already or will become more significant for legal-historical science.

Visual legal-historical studies might also explore:

- Which media incorporate visual legal sources (e.g., parchment, mural, stone, canvas, wood, paper, post card, computer screen)?

- How do the media in which visual legal sources are incorporated affect these sources?

- How do media and their contents impact the production, distribution, reception, and perception of visual legal sources?

$-\quad \ldots$

- The history of

- the legal-historical discourse on visual sources

- legal-historical image archives, image collections, image databases and "libraries"

- the digitalization and long-term preservation of visual legal sources

- visual legal-historical studies, their research and teaching projects, and scholarly events

$-\quad \ldots$.

Despite the pressing challenges of visualization, my suggestions will probably still seem utopian: visual historical studies are only just beginning to establish themselves. ${ }^{135}$ This suggests that, at some future point, legal historians will need to observe the insights of historical science, its neighboring discipline, and of its visual

134 See, e.g., Kocher, Zeichen und Symbole des Rechts, 40.

135 See, e.g., Paul, "Von der Historischen Bildkunde zur Visual History," 7. 
branch, visual historical studies. When that happens, we will have to determine the requirements to be met by visual legal-historical studies.

\subsubsection{Visual legal theory}

Visualization is not yet a major topic in legal theory. Even so, let us briefly consider visual jurisprudencethat is, what might be called visual legal theory. ${ }^{136}$

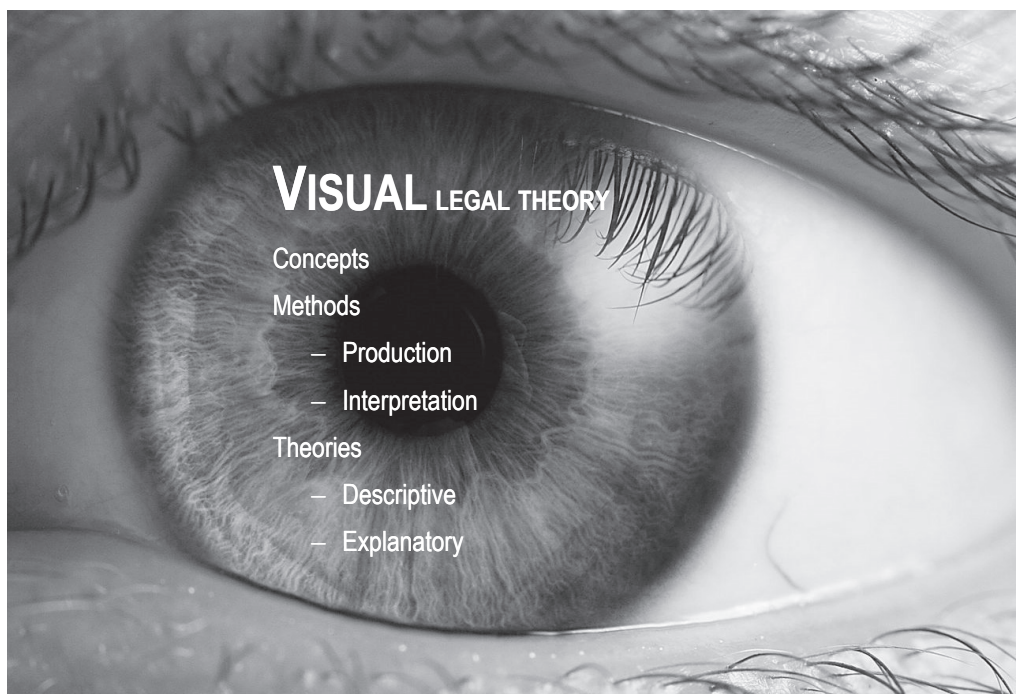

Figure $7^{137}$

I make six fundamental points:

First, legal theory examines (basic) legal concepts. ${ }^{138}$ For instance, it asks "What is law?"139 By analogy, it could also ask: What is "visual law"?

Second, legal theory is "not confined to positive law;"140 it "transcends [legal; my insertion] systems."141 It concentrates neither on a particular legal system ${ }^{142}$ nor on a specific branch of law. ${ }^{143}$ According to McLeod, "[...] legal theory involves a progression from the study of laws to the study of law." "44 Visual law could thus be studied beyond the confines of a specific legal system or a particular branch of law.

136 In this paper, I use "visual jurisprudence" and "visual legal theory" interchangeably. Penner, Schiff, and Nobles note that "[...], it is a peculiarly Anglo-American idea to treat legal theory as being more or less synonymous with jurisprudence (Penner, Schiff, and Nobles, "Approaches to Jurisprudence, Legal Theory, and the Philosophy of Law," 2).

137 Figure 7 shows an "Eye iris": https://de.wikipedia.org/wiki/Auge\#/media/Datei:Eye_iris.jpg (last accessed November 30, 2020). This image is available in the public domain.

138 See, e.g., Röhl and Röhl, Allgemeine Rechtslehre, 1, 7, 9; Weber-Grellet, Rechtsphilosophie und Rechtstheorie, 135, marginal number 179; Kunz and Mona, Rechtsphilosophie, Rechtstheorie und Rechtssoziologie, 94, marginal number 197; Wacks, Understanding Jurisprudence, 1, 5-6; Funke, "Rechtstheorie," 45, marginal number 1.

139 Wacks, 1. See also Röhl and Röhl, 1, 17; Weber-Grellet, 135, marginal note 179; Wacks, 5; Funke, 46, marginal note 3.

140 Original citation: "nicht auf das geltende Recht beschränkt" (Kaufmann, "Rechtsphilosophie, Rechtstheorie, Rechtsdogmatik," 9. Similarly, see Kunz and Mona, 95 marginal number 197).

141 Original citation: "verfährt grundsätzlich systemtranszendent" (Kaufmann, 9).

142 See, e.g., Penner, Schiff, and Nobles, 3; Kaufmann, 9; McLeod, Legal Theory, 2; Sauer, "Juristische Methodenlehre," 177, marginal number 5; Potacs, Rechtstheorie, 16.

143 See, e.g., Penner, Schiff, and Nobles, 3; McLeod, 1-2.

144 McLeod, 2. Similarly, Potacs, 27. 
Third, legal theory describes how law is organized. ${ }^{145}$ It could thus suggest how to systematize visual law (see Figure 5).

Fourth, legal theory is not oriented toward doctrinal legal research. ${ }^{146}$ This also applies to visual jurisprudence.

Fifth, legal theory is concerned with methods. ${ }^{147}$ It involves, for instance, methods aimed at determining the meaning of oral or written legal statements (i.e., hermeneutical methods). ${ }^{148}$ Where producing written or oral texts is concerned, legal theory investigates rhetorical methods. ${ }^{149}$ Regarding visual jurisprudence, the method of visual rhetoric is paramount for producing visualizations. ${ }^{150}$ With respect to interpreting legal visualizations, traditional legal theory (which focuses on written or oral texts) has not (yet) been developing what I would tentatively call visual legal hermeneutics. ${ }^{151}$ Thus far, legal methods and legal methodology are verbocentric.

Sixth, legal theory is concerned with theories ${ }^{152}$ and could therefore develop descriptive and explanatory theories, for instance, of visual law. The structural models presented here approach a descriptive theory of visual law, because they make explicit assumptions about its subject matter (see Figure 4) and its branches (see Figure 5). Media theory, for instance, offers visual law an explanatory theory because it seeks to explain why legal visualization emerges. More specifically, media theory shows how digital media and their contents affect law. Thankfully, Collins, Skover, and Katsh predicted some time ago that "the coming age of electronic media will rework law as profoundly as the printing press once did." ${ }^{153}$ Considering law in a digital world, Katsh states: "The varied possible uses of visual communication mean that different facets of law will likely employ the visual in different ways." 154 Elsewhere, he observes that the "new technologies bring us closer to graphical means of communication, [...]." ${ }^{\prime 155}$ These reflections constitute one of the first important components of an explanatory theory of legal visualization, and hence also of visual law.

\subsubsection{Visual sociology of law and visual sociology Visual sociology \\ Status and scope}

Sociology consists of general sociology and specific branches. ${ }^{156}$ Although mainstream sociologists still consider images to be peripheral, ${ }^{157}$ visual sociology has emerged in recent decades as one branch of sociology, ${ }^{158}$ is increasingly gaining recognition, ${ }^{159}$ and producing more and more publications. ${ }^{160}$ The progressively greater significance of visual sociology might contribute to establishing a new research direction within the sociology of law: the visual sociology of law (see below).

145 See, e.g., Kaufmann, 10; Kunz and Mona, 43, marginal note 2; Funke, 45, marginal note 1; Potacs, 16.

146 See, e.g., Funke, 45, marginal note 2.

147 See, e.g., Röhl and Röhl, 603-12; Weber-Grellet, 135, marginal note 179; Kunz and Mona, 95, marginal number 197.

148 See, e.g., Kunz and Mona, 98, marginal number 209; Potacs, 81-85, 167-209.

149 See, e.g., Röhl and Röhl, 3.

150 See, e.g., Brunschwig, Visualisierung von Rechtsnormen, 81-99.

151 On the absence of visual legal hermeneutics, see, e.g., Boehme-Neßler, Pictorial Law, 183; Mezey, "The Image Cannot Speak for Itself," 3-4; Porter, "Taking Images Seriously," 1766.

152 See, e.g., Funke, 45-46, marginal number 2.

153 Ross, "Communications Revolutions and Legal Culture," 638.

154 Katsh, 158.

155 Katsh, 168. Similarly, see, e.g., Feigenson and Spiesel, 1-33; Sherwin, Visualizing Law in the Age oft he Digital Baroque, $13-55$.

156 Endruweit, "Soziologie, Allgemeine und Spezielle," 487-88.

157 See, e.g., Grady, "Becoming a Visual Sociologist," 83; Harper, "Visual Sociology," 54; Wagner, "Contrasting images, complementary trajectories," 164; Burri, "Bilder als soziale Praxis," 342.

158 On the emergence of visual sociology, see, e.g., Grady, "Becoming a Visual Sociologist," 83; Ayaß, "Soziologie, visuelle," 496.

159 See, e.g., Harper, "Visual Sociology," 67.

160 See, e.g., Breckner, "Bildwahrnehmung - Bildinterpretation," 144; Nathansohn and Zuev, "Sociology of the Visual Sphere," 1. 
What might "a decidedly sociological perspective on images, films, and other forms of visual communication"161 look like? Visual sociology focuses on images as "objects of investigation in their own right."162 As such, these artifacts introduce "an entirely new type of information into the discipline of sociology as a whole."163 As a field of research and teaching, ${ }^{164}$ visual sociology "employs images [...] to analyze society [...]"165 because it views them as social phenomena. ${ }^{166}$ As such, it explores how images relate to society ${ }^{167}$ and are sources of social information. Visual sociology explores visual society or, put differently, the visual in society. It comprises manifold approaches. ${ }^{168}$ Despite its image-based epistemological thrust, visual sociology also raises meta-questions: "Are images per se a proper object of inquiry for sociologists [...]? Or is it more appropriate to treat them as an important, but hardly defining, dimension of traditional subject areas [of sociology, my insertion]? What about the visible social world, or imagery of the social order? Are these at the heart of sociological inquiry, or are they footnotes, appendices, oddities?"169 Below, I concentrate on images, methods, and theories. ${ }^{170}$

\section{Images - Production and Products}

Visual sociology studies the production of images and images as productions or products. ${ }^{171}$

\section{Production}

Visual sociology regards image production as a social practice ${ }^{172}$ and investigates the contexts in which this creative visual acting or doing occurs. ${ }^{173}$ It is also concerned with its own visual practice, which involves gathering visual data and visualizing sociologically relevant contents. Today, sociologists gather visual data, particularly by photographing or filming "the visual dimensions of social life." 174 In visualizing mental, spoken, or written contents, they produce, for instance, "maps, graphs, tables, charts and models [...]."175 Visual sociologists also reflect on (their own) visual practice, considering visual media (e.g., photographic cameras, video cameras, and film cameras) and their deployment in the research process. ${ }^{176}$ They examine why they or other actors produce images, for instance, "to communicate within a community that can understand that information and for which it must have some importance"177 and "to manage social relations."178

\footnotetext{
161 Original citation: "eine dezidiert soziologische Perspektive auf den Umgang mit Bildern, Filmen und anderen Formen der visuellen Kommunikation" (Schnettler und Baer, "Perspektiven einer visuellen Soziologie," 7; original emphasis).

162 Wagner, 163.

163 Grady, "The Scope of Visual Sociology," 21.

164 See, e.g., Grady, "The Scope of Visual Sociology," 12.

165 Grady, "Visual Sociology," 63.

166 See, e.g., Nathansohn and Zuev, 3.

167 See, e.g., Burri, "Visual rationalities," 46.

168 See, e.g., Harper, "Visual Sociology," 55. Similarly, see Breckner, 144.

169 Wagner, 163.

170 See, e.g., Ayaß, "Soziologie, visuelle," 496.

171 See, e.g., Grady, "The Scope of Visual Sociology," 13, 18.

172 See, e.g., Burri, "Visual rationalities," 54.

173 See, e.g., Burri, "Visual rationalities," 54.

174 Wagner, 161. See also Harper, "Visual Sociology," 55; Grady, “The Scope of Visual Sociology," 18.

175 Grady, "The Scope of Visual Sociology," 18.

176 See, e.g., Burri, "Bilder als soziale Praxis," 343-44.

177 Grady, "The Scope of Visual Sociology," 14.

178 Grady, "The Scope of Visual Sociology," 17.
} 


\section{Products}

In order to reflect on society, visual sociologists use images, ${ }^{179}$ which provide the framework for visualsociological analysis. ${ }^{180} \mathrm{Key}$ issues include sociological concepts of images, ${ }^{181}$ the various types of sociologically relevant images, ${ }^{182}$ sociologically relevant image contents and their functions, ${ }^{183}$ the social significance of images, ${ }^{184}$ observing and explaining the social effects of images, ${ }^{185}$ communication with images (e.g., usage, ${ }^{186}$ distribution, contexts, visual strategies ${ }^{187}$ ), and how social actors, above all sociologists, relate to images. ${ }^{188}$

Given these many issues, I confine myself to sociologically relevant contents, i.e., images that contain social contents. ${ }^{189}$ In other words, "images [can; my insertion] constitute rich sources of information about quite varied aspects of social [...] life." ${ }^{190}$ Such images visually describe, interpret, and construct those aspects. ${ }^{191}$ They involve, for example, "social issues," 192 "portraits of sociologists"193 or other social actors, social roles, ${ }^{194}$ social status, ${ }^{195}$ social problems, ${ }^{196}$ interpersonal relations,${ }^{197}$ person-object relations,${ }^{198}$ social behavior ${ }^{199}$ ("social interactions," 200 communicative actions) in various contexts, social processes, ${ }^{201}$ and the effects of social and legal norms. ${ }^{202}$ In summary, "images focus on the visible aspects of objects and social situations, that is, they shape abstract ideas, thoughts, notions, phantasies as visible."203

\section{Methods: "Doing Sociology Visually"}

Essentially, sociological methods are verbocentric. ${ }^{204}$ Visual sociology, however, “[...] is committed to using visual methods for research [...]." ${ }^{205}$ On the one hand, these methods involve visually analyzing society by producing images; on the other, they concern analyzing visual society, i.e., socially relevant images.

179 See, e.g., Grady, "The Scope of Visual Sociology," 13.

180 See, e.g., Grady, "The Scope of Visual Sociology," 13.

181 See, e.g., Burri, "Bilder als soziale Praxis," 342, 348-49; id., "Visual rationalities," 46; Schnettler and Baer, 14.

182 See, e.g., Grady, "The Scope of Visual Sociology,” 12; id., "Visual Sociology," 64.

183 See, e.g., Burri, "Visual rationalities," 49. Burri examines the functions of images in medical research and practice.

184 Social significance refers, for instance, to "[...] the role of visual imagery and the visual in the work of sociologists, [...] and others 'interested in social [...] processes"' (Wagner, 165). In these contexts, visual sociologists explore the value of images for sociological inquiry.

185 See, e.g., Burri, "Visual rationalities," 46. Burri describes the impacts of images in hospitals: "In the daily hectic environment of the hospital or clinic, images simplify work processes because they allow one to grasp information in a very short time. [...] This advantage of images is important in both diagnostic and operation practices" (Burri, "Visual rationalities," 49).

186 See, e.g., Burri, "Visual rationalities," 54.

187 See, e.g., Grady, "Visual Sociology," 65.

188 See, e.g., Harper, "Visual Sociology," 64; Grady, "The Scope of Visual Sociology," 10.

189 See, e.g., Grady, "The Scope of Visual Sociology," 12.

190 Grady, "Visual Sociology," 65. Similarly, see id., "The Scope of Visual Sociology," 10.

191 See, e.g., Breckner, 147.

192 Grady, "Becoming a Visual Sociologist," 105, 110.

193 Original citation: "Portraits von Soziologen" (Ayass, "Editorial," 113).

194 See, e.g., Harper, "Visual Sociology," 56.

195 See, e.g., Harper, "Visual Sociology," 65.

196 See, e.g., Harper, "Visual Sociology," 56; Grady, "Becoming a Visual Sociologist," 110

197 See, e.g., Harper, "Visual Sociology," 61.

198 See, e.g., Harper, "Visual Sociology," 61; Grady, "Becoming a Visual Sociologist," 85.

199 See, e.g., Grady, "Visual Sociology," 64.

200 Burri, "Visual rationalities," 47. Similarly, see Breckner, 162.

201 See, e.g., Wagner, 165.

202 See, e.g., Harper, "Visual Sociology," 57.

203 Original citation: "Bilder fokussieren auf die sichtbaren Aspekte von Gegenständen und sozialen Situationen bzw. gestalten abstrakte Ideen, Gedanken, Vorstellungen, Phantasien als sichtbare ([...])" (Breckner, 147; original emphases).

204 See, e.g., Ayass, "Editorial," 116.

205 Grady, "Visual Sociology," 2007, 63. 


\section{Production: Analyzing society visually}

Visual sociology considers image production theoretically and practically. Both approaches inquire how to produce images and seek to fathom "the intellectual prerequisites of this activity [...]." 206 Further, it considers visual media (e.g., "cameras, minidisk recorders, handheld positioning system receivers, eye-tracking machines, and many other emerging technologies"207) to be "methodological instruments to achieve empirical data and produce new sociological knowledge ([...])." 208

There seem to be two main approaches: visual social data gathering ${ }^{209}$ and visualizing sociologically relevant mental, oral, and written contents. ${ }^{210}$ Sociologists perform the first task themselves or assign others (often the subjects of sociological research) to produce relevant images: "In this type of research, recording devices are handed over to subjects. Examples include drawings by children $([\ldots])$, their photographs $([\ldots]),[\ldots] .{ }^{\prime 211}$ Sociologists gather visual data by taking a certain perspective and by embedding the selected persons, objects, events, actions, situations, etc. ${ }^{212}$ in the image frame (composition). ${ }^{213}$

Applied visual sociology produces images in practical contexts. For instance, in child abuse investigations images or imaging techniques are used as they apparently "elicit the most reliable and valid information" and "encourage free recall by jogging children's memory with photographs or imaging excercises."214

\section{Products: Analyzing visual society}

Analyzing visual society has many facets. These include visual data acquisition, the visual perception of the social environment, describing and interpreting images, and visual communication, which "is organized socially." 215

Visual sociologists search for and collect images ${ }^{216}$ and hence also have recourse to visual databases. ${ }^{217}$ They select images that enable investigating specific research topics ${ }^{218}$ and "working on a specific research problem $[\ldots] . " 219$

Visual sociologists explore how people perceive their (social) environment. Images may be part of this context and hence allow scholars to study perceptions ${ }^{220}$ and inquire how a specific environment impacts image perception.

How social actors perceive images affects their descriptions and interpretations. Visual sociologists are "concerned with the meanings of a culture's visual representations [...]."221 They also describe and interpret "the content of a set of images [...]"222 or the content of particular images. ${ }^{223}$ Performing this analytical work, visual sociologists do "not focus on images alone but take the social practices and contexts of image produc-

\footnotetext{
206 Grady, "The Scope of Visual Sociology," 13.

207 Grady, "Visual Sociology," 68.

208 Burri, "Visual rationalities," 47. See also id., "Bilder als soziale Praxis," 343-44.

209 See, e.g., Harper, "Visual Sociology," 55.

210 See, e.g., Grady, "Visual Sociology," 69; Nathansohn and Zuev, 1; Schnettler and Baer, 13.

211 Grady, "Visual Sociology," 66. See also Breckner, 144.

212 See, e.g., Ayass, "Editorial," 116.

213 See, e.g., Breckner, 147.

214 Grady, "Visual Sociology," 69.

215 Grady, "The Scope of Visual Sociology," 14.

216 See, e.g., Harper, "Visual Sociology," 55.

217 See, e.g., Nathansohn and Zuev, 6.

218 See, e.g., Grady, "Becoming a Visual Sociologist," 111.

219 Harper, "Visual Sociology," 55.

220 See, e.g., Grady, "Visual Sociology," 64; Burri, "Bilder als soziale Praxis," 346; Breckner, 148-49.

221 Grady, "Visual Sociology," 63.

222 Grady, "Visual Sociology," 64.

223 See, e.g., Grady, "The Scope of Visual Sociology," 10.
} 
tion, interpretation, and use into account." 224 Therefore, apart from image content, contextual aspects play a role in more deeply understanding images. ${ }^{225}$ Regarding image content, "various dimensions and aspects of social worlds are analyzed." ${ }^{226}$ Visual sociologists raise various questions:

- Researcher-related questions:

- What kind of sociological knowledge do we need to describe and interpret images?227 To expand this question: What kind of knowledge and how much knowledge do sociologists require to describe and interpret images?

- "What do we [sociologists; my insertion] want from the image?"228

- "What have we found out and what more do we need to know?"229

- "What kinds of [sociologically-relevant; my insertion] information can we [my emphasis] actually get from the image?" 230

- Image-related questions:

- Content-related questions:

- Person-related questions:

- Who does the image represent?231

- How does the image represent persons?232

- How do persons relate to one another?233

- What roles do these persons assume? ? $^{234}$

- What is their status?

- Object-related questions:

- What objects does the image represent?

- How do they relate to persons, how to other objects?

- Event- or action-related questions:

- "What kinds of [social; my insertion] events are displayed?"235

- What social actions are being performed? ? $^{236}$

- Context-related questions:

- "What has been done with the image? Delineates the social history of how and image has been produced and consumed." 237

- How does the context in which images have been created impact their description and interpretation? ${ }^{238}$

224 Burri, "Visual rationalities," 54. Similarly, see id., "Bilder als soziale Praxis," 354.

225 See, e.g., Breckner, 162; Nathansohn and Zuev, 3.

226 Original citation: "werden verschiedene Dimensionen und Aspekte sozialer Welten zum Gegenstand der Analyse gemacht: [...]" (Breckner, 145).

227 See, e.g., Grady, "Becoming a Visual Sociologist," 94. See also id., "Becoming a Visual Sociologist," 97.

228 Grady, "The Scope of Visual Sociology," 15.

229 Grady, "The Scope of Visual Sociology," 15.

230 Grady, "The Scope of Visual Sociology," 15.

231 See, e.g., Grady, "Becoming a Visual Sociologist," 92.

232 See, e.g., Grady, "Becoming a Visual Sociologist," 92.

233 See, e.g., Grady, "Becoming a Visual Sociologist," 97.

234 See, e.g., Grady, "Becoming a Visual Sociologist," 97.

235 Grady, "Becoming a Visual Sociologist," 92.

236 See, e.g., Grady, "Becoming a Visual Sociologist," 92.

237 Grady, "The Scope of Visual Sociology," 15.

238 See, e.g., Raab, "Visuelle Wissenssoziologie der Fotografie," 122, 130-32. 
- Actor-related questions: Why, how, how far, and with which effects do social actors communicate gathered visual data? Moreover, why, how, how far, and with which effects do these actors visualize sociologically relevant contents?

\section{Theoretical approaches}

According to Breckner, (visual) sociology has not yet developed a comprehensive visual theory. ${ }^{239}$ Based on a growing number of studies, visual sociologists are attempting to advance a visual theory, among others, by systematically revealing the subject matter and methods of visual sociology.

Their descriptive theoretical approaches address various questions: What are sociologically relevant images? How does visual sociology delineate them against sociologically relevant texts? What functions do images have in society, particularly in sociology? ${ }^{240}$ How significant are images in society, specifically in sociology? ${ }^{241}$ Descriptive theoretical approaches develop visual methods and therefore a visual methodology. Explanatory theoretical approaches: "Explanatory theories formulate a hypothesis about the causal connections between something requiring explanation and a factor that serves as the explanation for the phenomenon under scrutiny." ${ }^{242}$ In reality, however, mostly more than just one hypothesis or factor are at stake. Visual sociology connects the social sphere with images, and thereby also considers the technological and economic factors impacting this relationship. Visual sociology as such seeks to understand and explain why images are increasingly emerging in society and sociology. Today's ongoing digital transformation is creating images by technologically facilitating visualization. ${ }^{243}$ Straightforward access to visual media (and their affordability) is also fostering visualization. ${ }^{244}$ The increasing permeation of everyday life with moving and still images is also generating new ways of dealing with visual phenomena. ${ }^{245}$

\section{Visual sociology of law \\ Status and scope}

The sociology of law is a subdiscipline of both law and sociology. It is practiced by legal scholars and by sociologists, although with different epistemological interests. ${ }^{246}$ In this paper, I concentrate on the sociology of law as practiced by legal scholars. Drawing on the insights of law ${ }^{247}$ and sociology, ${ }^{248}$ the sociology of law investigates how law and social life impact each other. ${ }^{249}$

The sociology of law studies the interplay of law and human visual actions (which are increasing in today's increasingly visual world). Another reason for investigating this interplay is that sociology understands "manners of acting, thinking, and feeling in society" 250 as social facts requiring empirical exploration. Legal facts are relevant to the sociology of law. 251 "Empirical social research on law is also called research of legal

\footnotetext{
239 See Breckner, 145.

240 See, e.g., Breckner, 145.

241 See, e.g., Burri, "Bilder als soziale Praxis," 342; Breckner, 144; Schnettler and Baer, 7.

${ }^{242}$ Mahlmann, "Legal Philosophy and Legal Theory," 87.

243 See, e.g., Burri, "Bilder als soziale Praxis," 346.

244 See, e.g., Schnettler and Baer, 9.

245 See, e.g., Schnettler and Baer, 7.

246 See, e.g., Rehbinder, Rechtssoziologie, 3-4, marginal note 5.

247 See, e.g., Estermann, "Rechtssoziologie," 63.

248 See, e.g., Graber, "Legal Sociology," 111.

249 See, e.g., Rehbinder, 1-2, marginal note 2, 4, marginal note 5.

250 Graber, 111.

251 On social facts, see, e.g., Rehbinder, 48-50, marginal notes 53-54; Graber, 111.
} 
facts." ${ }^{252}$ Legal facts relate to legal reality ${ }^{253}$ or legal life. ${ }^{254}$ Given that legal and other actors act with and through images, the sociology of law examines the resulting visual legal facts. It describes, analyzes, and explains in which contexts, how, and to what extent legal and other actors act with and through legal images. Here, "contexts" are both legal contexts-legislation, positive law, legal practice (e.g., visual court practice, visual e-justice, visual lawyering, visual prosecuting, visual e-government and administration, visual policing), and legal science (e.g., visual legal research and visual legal education)—and extra-legal contexts (e.g., mass media, visual art).

In 2001, Röhl and Ulbrich observed that "sociology is only now beginning to discover the significance of visual communication." 255 This view is somewhat astonishing given that "modern visual sociology began as part of the rejection of dominant paradigms during the 1960s." 256 There appears to be a time lag of at least 40 years in (German-speaking) sociology of law. Whereas German-speaking sociology of law does not explicitly have recourse to visual sociology, ${ }^{257}$ English-speaking scholars have pointed to visual sociology ${ }^{258}$ and suggested how to outline a visual sociology of law. ${ }^{259}$

The analog age, which preceded today's digital world, can be divided into three periods: oral-aural, manuscript, and print. ${ }^{260}$ Considering the analog-to-digital transition, Struck notes: "On the edge to a new era, we feel like fish that have lived in the Niagara headwaters and are now sucked into the waterfall; these fish will not know what hit them and, being halfway, will struggle to develop a theory of the waterfall." ${ }^{261}$ Although visual sociology is not strongly present in German-speaking legal-sociological discourse, it discusses issues that touch on the visual sociology of law. I introduce some of these issues below and suggest which other points of visual sociology that the visual sociology of law could take up mutatis mutandis.

252 Original citation: "Empirische Sozialforschung, das Recht betreffend, nennt man auch Rechtstatsachenforschung ([...])" (Rehbinder, 48, marginal note 52).

253 See, e.g., Baer, Rechtssoziologie, 41, marginal note 66.

254 See, e.g., Baer, 43, marginal note 73.

255 Original citation: "Die Soziologie beginnt gerade erst, die Bedeutung der visuellen Kommunikation zu entdecken" (Röhl and Ulbrich, "Visuelle Rechtskommunikation," 359).

256 See, e.g., Harper, "Visual Sociology," 67.

257 See, e.g., Hesse, Einführung in die Rechtssoziologie; Raiser, Grundlagen der Rechtssoziologie; Rehbinder, Rechtssoziologie; Baer, 78-80, marginal notes 86-91, 160-61, marginal notes 221-23, 276-77, marginal notes 27-29; Stegmaier, "Recht und Normativität aus soziologischer Perspektive," 67-90, marginal notes 1-72.

258 See, e.g., Bischoping, Chapman-Nyaho, and Raby, "Linking Visuality to Justice through International Cover Designs for Discipline and Punish," 184; Walby, "Reflections on Visual Methods from a Study of Manitoulin Island's Penal History Museums," 264; Mulcahy, "Eyes of the Law," S112.

259 Mulcahy, "Eyes of the Law," S113.

260 Marshall McLuhan's media theory goes in a similar direction. Since his theory dates back to the 1960s, I refer to contemporary discussions of this theory: "The present and the future are the result of a second communictions revolution, in which print is supplanted by electronics. For McLuhan, too, the remote past breaks naturally into three sections, the strictly oral-aural period before the invention of the alphabet and writing, the ideographic East, and the manuscript culture of medieval Europe" (Hickman, Philosophy, Technology, and Human Affairs, 129; original emphases). "The historical evolution of the media, according to McLuhan, who in this seems to follow Harold Innis $(1950,1951)$, is from orality to literacy, from the spoken word to manuscripts and from there to print and then electronic media (McLuhan 2002 [1962]). Each media epoch was characterized by different life styles, cultures, trends, economies, and also policital systems (Innis, 1951; McLuhan, 2002 [1962])" (Siapera, Understanding New Media, 6).

261 Original citation: "An der Bruchkante zu einer neuen Ära geht es uns wie einem Fisch, der im Oberlauf des Niagara gelebt hat, [sic] und der nun in den Sog das [sic] Wasserfalls geraten ist; diesem Fisch wird Hören und Sehen vergehen, und er wird Mühe haben, wenn er auf halber Höhe eine Theorie des Wasserfalls entwickeln will” (Struck, Rechtssoziologie, 164). 


\section{Images - Production and Products \\ Production}

Sociologists of law collect visual data that have been produced for various legal contexts. Langer, for instance, reviewed legal-educational literature (181 publications) to establish whether, how many, and which types of images this literature contains. ${ }^{262}$ To my knowledge, sociologists of law have not yet photographed or filmed "the visual dimensions of" 263 legal life or legal reality. Sociologists of law consider the visual actions of persons or institutions within and outside the legal context. Extra-legal actions include the images of law created by artists, the mass media, and other non-legal actors (e.g., laypeople). While sociologists of law have thus far not reflected on their own visual actions, they nevertheless visualize the content of their (empirical) studies (e.g., in form of tables or tabular overviews, ${ }^{264}$ column diagrams, ${ }^{265}$ and other types of legal images). Further, they examine the intentions of the authors or users of legal images, among others, in legal-educational literature ${ }^{266}$ or legal teaching. ${ }^{267}$ In conclusion, I posit first that (legal) actors produce legal images to convey knowledge or information about the law and second that legal images are produced to enable people to better cope with law.

\section{Products}

Sociologists of law study legal images to reflect on legal life. They consider and develop the legal-sociological concept of "image." They also discern the types of such images ${ }^{268}$ the image contents relevant to the sociology of law, the functions of legal images, ${ }^{269}$ their significance ${ }^{270}$ and (potential) effects, ${ }^{271}$ how and to which extent (legal) actors communicate with and through legal images (e.g., usage, distribution, persuasive strategies $^{272}$ ), and how legal actors (e.g., sociologists of law) behave toward these images.

262 See Langer, Die Verbildlichung der juristischen Ausbildungsliteratur, 9-13.

263 Wagner, 161.

264 See, e.g, Henze, Bildmedien im juristischen Unterricht, 35 (table 1); 41 (table 2); 44 (table 3); 47 (table 4); 49 (table 5); 51 (table 6); 59 (table 7); 75 (table 8); 77 (table 9); 81 (table 10); see Langer, Die Verbildlichung der juristischen Ausbildungsliteratur, 8 (tabular overview 1); 12 (tabular overview 2); 19 (tables 4 and 5); 21 (table 6); 24 (table 7); 25 (table 8); 45 (table 9); 46 (table 10); 49 (table 11); 67 (table 12); 68 (table 13); 69 (table 14); 70 (tables 15 and 16); 71 (table 17); 74 (table 18); 75 (table 19); 78 (table 20); 79 (table 21); 81 (table 22); 99 (tabular overview 3); 124 (tabular overview 3) [sic; [4]].

265 See, e.g., Henze, 29, fig. 1; 31, fig. 2; 32, fig. 3; 34, fig. 4; 35, fig. 5; 40, fig. 6; 42, fig. 7; 43, fig. 8 .

266 See Langer, 13.

267 See, e.g., Henze, 15.

268 For instance, Röhl and Ulbrich distinguish "zwischen Bildern vom Recht und Bildern im Recht" ["between images of law and images in law"] (Röhl and Ulbrich, 356). See also Silbey, "Images in/of Law," 179-81. "Bilder im Recht sind solche, die innerhalb des Rechtssystems, also in der rechtsinternen Kommunikation, Verwendung finden. Bilder vom Recht dagegen dienen der Kommunikation über das Recht, wie sie ausserhalb des Rechtssystems im engeren Sinne, also vor allem in den Massenmedien, aber auch in der Kunst, in der Literatur oder im Alltag stattfinden" ["Images in law are those that are used inside the legal system, thus within legal communication. Images of the law, however, serve communication about the law, as it occurs outside the legal system in a narrow sense, that is, especially in the mass media, but also in art, in literature or in everyday life"] (Röhl and Ulbrich, 356-57). On the types of images that are used in the legal context, see, e.g., ids., 364-70. The authors do not distinguish visual and audio-visual communication in the legal context. On the types of images that are used in communication outside the legal context, see, e.g., ids., 370-71.

269 See, e.g., Röhl and Ulbrich, 357-81, especially 377. Under the heading "Kommunikative Funktionen des Bildgebrauchs" ["Communicative functions of image use"], Röhl and Ulbrich discuss not only these functions but also how to answer the question what an image is (see 372), the meaning of images (see 372-73), "visual literacy"” (373), the difference between analog and digital communication (see 374-75), the concept of "symbol" (375), and the effects of images (see 378-81). Although all these topics are interrelated with the communicative functions of images, they need to be dealt with separately. This ought to help legal scholars avoid confounding the communicative functions of textually represented law with what law is, what it means, what verbal literacy encompasses, how analog and digital verbal communication differ, and what the effects of verbal legal communication are. To establish the functions of legal images, sociologists of law should empirically investigate the intentions of those who use and distribute these images (and which persuasive strategies they serve).

270 See, e.g., Röhl, "Das Recht nach der visuellen Zeitenwende," 339-40; Mulcahy, "Eyes of the Law," S113.

271 See, e.g., Röhl and Ulbrich, 357, 381-85; Röhl, "Das Recht nach der visuellen Zeitenwende," 341-44.

272 See, e.g., Silbey, "Images in/of Law," 183. 
In terms of contents, images relevant to legal-sociological discussion convey information about various aspects of legal life or reality-i.e., how does the living law manifest visually? Examples include visually apparent law in action, i.e., "[...] what legal institutions [and legal actors; my insertion] do, and how they do it." ${ }^{273}$ Further, depictions of legal actors and legal institutions may visualize legal roles: "Who occupies legal roles - lawyers, judges, policemen [prosecutors, law professors; my insertion] — and what do the roleplayers do?" 274 These visuals may also provide information about the status of legal actors. Considering judges, Moran raises various questions: "What images of judges are used in the news stories that are made under the current prohibitions on image-making in courts? What aesthetic traditions do these images draw on? What role do these images play in telling (and selling) news stories? What do pictures of the judiciary in newspapers tell us about the judiciary and judicial authority?"275 These questions could also apply mutatis mutandis to other legal actors. Images that pertain to the sociology of law may visualize legal problems, interpersonal legal relationships, legal relationships between persons and things, interactions among legal actors in various contexts, legal events, visible social functions and effects of law, etc. Which media convey images with such contents?

\section{Methods}

The visual sociology of law examines how (legal) actors produce legal images ${ }^{276}$ and which knowledge these actors must have for this purpose. It also explores the methods that need to be applied in order to cope with already created images that are relevant to the sociology of law.

Regarding the production of legal images, the sociology of law needs to query how its actors could apply the methods of visual sociology mutatis mutandis to the sociology of law. ${ }^{277}$ In analyzing the visual dimensions of legal life, the aspects that I mentioned above are also relevant: visual legal data acquisition, visual perceptions of legal life, describing and interpreting legal images, ${ }^{278}$ and visual legal communication. Visual sociologists of law search for and collect images that help explore the visual dimensions of legal life (as yet, however, there seem to be no databases of modern legal images). Based on such images, they study how people perceive and interact in legal life. Further, they focus on how legal situations impact perceptions and hence how actors describe and interpret these images. According to Silbey, "Translating images into words in order to compare them to what we understand through sight is a troubling problem for law. We need to be sure of the facts contained in the image, the relevance of the image, its perspective, its potential bias, its partiality, and its ambiguities." ${ }^{279}$ In turn, Röhl observes that legal images "acquire meaning from the history of their making and from the way they are used." 280 The questions relevant to visual sociology (see above) could be transferred mutatis mutandis to the sociology of law. They include: What kind of legal-sociological knowledge is needed to describe and interpret legal images? What information can we gain from legal images that is relevant to the sociology of law? For instance, what is the factual or normative meaning of such images? Do they help answer factual or legal questions, or both? ${ }^{281}$ How do these images represent legal actors and things? What kinds of legal events

\footnotetext{
273 Friedman, "Legal Culture and Social Development," 33.

274 Friedman, 40.

275 Moran, "Every Picture Speaks a Thousand Words," 32. These questions are also relevant to law-and-visual-culture studies (see below 4.2.2.).

276 See, e.g., Mulcahy, "Eyes of the Law," S113.

277 See, e.g., Walby, 268.

278 See, e.g., Walby, 273-85.

279 Silbey, "Images in/of Law," 172 (the author mainly refers to visual evidence).

280 Original citation: "erhalten Bedeutung aus der Geschichte ihrer Entstehung und aus der Art ihrer Verwendung" (Röhl 2003, 341 ).

281 See, e.g., Silbey, “Images in/of Law,” 176.
} 
are visually evident? How do the legal or extra-legal contexts of legal image production influence how such images are described and interpreted?

\section{Theoretical approaches}

Visual sociology, as suggested, has thus far not developed a comprehensive visual theory, even less so the sociology of law. Two approaches might help advance theorizing. The first are descriptive approaches, which raise questions such as: How might we describe images that are relevant to the sociology of law? How could we define such images in the context of texts that are relevant to this discipline? ${ }^{282}$ How significant are (legal) images in legal life or reality for the sociology of law? How to develop visual methods or a visual methodology for the sociology of law? Second, explanatory approaches seek to understand why images are increasingly pervading legal life, ${ }^{283}$ that is, why "the law as well — has gone visual." ${ }^{284}$ Both approaches (descriptive and explanatory) concern how digitalization is visually impacting legal life. Obviously, technical factors play a part: "[...], digital technologies make it much easier to produce, modify, and disseminate pictures (and sounds), people without special training or skills can express their thinking visually and share it with others." 285 With society relying increasingly on visual communication, societal factors are also contributing to legal visualization. ${ }^{286}$ Economic factors, too, are promoting the growing visualization of law: "What is different today is that digital tools have made it [...] cheaper for just about everyone to create, modify, and deploy pictures of all kinds." ${ }^{287}$ Explanatory approaches belong to "social theories of law." These "deny, altogether or in large part, any notion of legal 'autonomy.' That is, these theories try to explain [visual; my insertion] legal phenomena by searching for causes and causal factors 'outside' the legal system." ${ }^{288}$ As such, they regard law as a dependent variable. They "assign a leading role in molding the shape of legal institutions and legal arrangements to systems or subsystems that society defines as 'non-legal,' that is, as economic, social, cultural, or political." ${ }^{289}$ Present and future theoretical approaches are likely to produce a theory of visual sociology of law at some stage.

282 On the difference between (legal) texts and (legal) images, see, e.g., Röhl, "Das Recht nach der visuellen Zeitenwende," 341.

283 See, e.g., Katsh, 133-71; Röhl and Ulbrich, 359 [referring to Katsh]; Mulcahy, "Eyes of the Law," S113-14.

${ }^{284}$ Feigenson and Spiesel, 10.

285 Feigenson and Spiesel, 3. See also ids., 17; see also Sherwin, When Law Goes Pop, 6, 8; Röhl and Ulbrich, 355-56; Almog, How Digital Technologies Are Changing the Practice of Law, 119. Astonishingly, Baer, a German sociologist, merely asks whether law will be affected by digital media (see Baer, 160, marginal note 221). Nevertheless, elsewhere she states: "Zudem gibt es Bilder, um deren Deutung und Bedeutung die Parteien dann streiten, oft als Fotos von Tatorten, also als Beweismaterial, weshalb im Jurastudium erlernt werden sollte, mit Bildern kompetent zu arbeiten (wie auch mit 'Bildern im Kopf', den oben behandelten Vorurteilen)' ["Moreover, there are pictures, whose interpretation and meaning are contested by the parties. Often, these are photographs of crime scenes, and hence evidentiary material. Therefore, legal education should teach how to work proficiently with pictures (as well as with 'mental images,' the aforementioned biases)"] (Baer, 246, marginal note 31). German, Austrian, and Swiss legal realities might not yet be as "visual" as US-American legal reality, which would justify Baer's caution. Elsewhere, she holds that "Recht [...] nicht nur von Texten [lebt], sondern, [...], auch von Zeichen ([...]), von den Bildern und bildlichen Vorstellungen wie Metaphern und

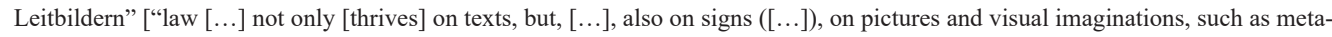
phors and overall concepts"] (Baer, 276, marginal note 27). Even though the author's statements need to be slightly modified from a semiotic perspective (texts also consist of signs, namely verbal signs, whereas pictures include iconic signs), she dares advance onto new terrain at the end of her book. In any event, further empirical studies are needed to inquire how and to what extent German, Austrian, and Swiss legal realities and those of other European jurisdictions have "gone visual."

286 See, e.g., Feigenson and Spiesel, 2, 17-18.

287 Feigenson and Spiesel, 2.

288 Friedman, "Law, Lawyers, and Popular Culture," 1580.

289 Friedman, "Law, Lawyers, and Popular Culture," 1580. 


\subsubsection{Law-and $\operatorname{areas}^{290}$}

\subsubsection{Law-and visual art}

In the English-speaking world, law-and visual art is rooted in law-and the humanities (see Figure 5). It is a subfield of this area. ${ }^{291}$ Law-and the humanities also encompasses, for instance, law-and the image, law-and architecture, as well as law-and literature.

Douzinas and Nead have observed that "The relationship between law and [visual; my insertion] art can be analytically distinguished into two components: law's art, the ways in which political and legal systems have shaped, used, and regulated images and art, and art's law, the representation of law, justice, and other legal themes in art [my emphasis]."292 "Art's law" amounts to "engaging with what works of art can reveal about law, [...]." ${ }^{293}$ Taking up this classification, Behrmann calls the representations of law, justice, and other legal themes "image-rules." 294 Her concept implies, however, that all these representations have obtained legal force, which is not always the case. For example, pictures of (Lady) Justice, court buildings, legal norm images used for educational purposes, contract visualizations, and so forth do not enter into legal effect like vó $\mathrm{or}$ (nómoi, statutes). Instead of "image-rules," I propose the term "legal images." Law-and visual art appears to be limited to works of art. ${ }^{295}$ However, legal visualizations without artistic value seem to fall off its epistemological grid. Unlike legal iconography (i.e., visual legal-historical science), law-and visual art focuses on doctrinal legal research, that is, the legal regulation of (legal) images. ${ }^{296}$

\subsubsection{Law-and visual persuasion}

Especially in the United States, "adventurous lawyers and receptive courts are now taking advantage of ubiquitous picturing tools to argue, explain facts in litigation documents." ${ }^{297}$ In order to advance their case, trial lawyers apply "visual strategies," 298 among others, using images as evidence or as arguments. ${ }^{299}$ If courts embed images in their opinions, to underscore their factual or legal considerations, I would not subsume this practice under law-and visual persuasion. ${ }^{300}$ In calling this visual judging, I am aware of using a term that falls out of the law-and discourse.

\subsubsection{Law-and visual culture}

Friedman ekes out two meanings of the term "legal culture." First, "ideas and attitudes about law which [...] lay people hold." ${ }^{301}$ Second, "books, songs, movies, plays and TV shows which are about law or lawyers, and which are aimed at a general public." ${ }^{302}$ Law-and-visual-culture studies take into account both meanings ${ }^{303}$ and examine their interrelations. ${ }^{304}$ Hence, on the one hand, this concerns laypeople's mental images of law

\footnotetext{
290 Since law and graphic design fall under legal design, I outline this area below (see 5.3.).

291 See, e.g., Sarat, Anderson, and Frank, "Introduction," 28-34.

292 Douzinas and Nead, "Introduction," 11. Similarly, see Mulcahy, "Eyes of the Law," S115, S119.

293 Mulcahy, "Eyes of the Law," S115.

294 Behrmann, 44.

295 See, e.g., Martyn and Huygebaert, 5.

296 See Behrmann, 44.

297 Porter, 1724.

298 Porter, 1748.

299 See, e.g., Porter, 1725-40.

300 See, however, Porter, 1740-44.

301 Friedman, "Law, Lawyers, and Popular Culture," 1580. See also id., "Law, Lawyers, and Popular Culture," 1599-1600, 1606.

302 Friedman, "Law, Lawyers, and Popular Culture," 1580. See also id., "Law, Lawyers, and Popular Culture," 1587 (here, Friedman also mentions newpapers).

303 On the further development of the concept of "legal culture," see, e.g., Silbey, "Legal culture and cultures of legality," 426-35

304 See, e.g., Friedman, "Law, Lawyers, and Popular Culture," 1592-98.
} 
and lawyers. On the other, visual legal culture manifests in "material" (still and moving) images of law. Other (mass) media besides those listed by Friedman include journals, magazines, and the Internet.

In high visual culture, law appears as a visual phenomenon (i.e., as visual legal art). As observed, Douzinas and Nead call this "art's law, the representation of law, justice, and other legal themes in art." 305 Take, for example, paintings of Lady Justice, or graphic illustrations of courtroom scenes and executions. Thus, the two law-and areas, law and high visual culture and law and visual art, form an interface.

Mass media that visually communicate about the law ${ }^{306}$ mostly participate in "low" (i.e., popular) visual culture. As such, they publish legal or legally relevant pictures. Without claiming to be art, they portray legal actors (e.g., lawyers, judges, law professors, prosecutors, defendants, litigants), represent legal objects (e.g., the inside or outside of courthouses, prisons, parliaments), or legal events (e.g., court scenes, execution of sentences, conclusion of contracts, negotiations). Studies in law-and-visual-culture examine how images of the law correspond to law, as well as resemble or differ from it. ${ }^{307}$ Examples include "the images of law in popular visual forms, highlighting the disjunction between the stories and characters on-screen with the reality of legal practice." ${ }^{308}$ Legal images of popular culture "may distort the law and its admirable purposes and processes." ${ }^{309}$ On one side, law-and-visual-culture studies explore how and to which extent images of the law affect laypeople. ${ }^{310}$ Such images may lead laypeople in particular to form negative ideas about legal life. ${ }^{311}$ On the other side, law-and-visual-culture studies consider how and how far images of law affect legal actors: "The shift in communication practices toward visual representations, including videos, computer-based animations, and reenactments, also reflects the growing influence of the visual mass media on the way trial lawyers represent their clients' interests." ${ }^{312}$ Such impact studies are part of audience research and also fall within the remit of the visual sociology of law.

\subsubsection{Law-and sight}

Take law and the senses - in our case law-and sight: In Law and the Senses, Bently asks: "How does law sense? [...] How does law control or regulate our senses? How does law use our senses? Which [of our; my

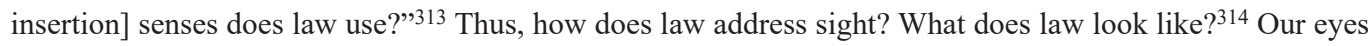
enable us to acquire legal knowledge and know-how, predominantly by looking at and reading written texts. Exceptionally, we gain such knowledge and know-how by looking at and analyzing visualizations. Visual law reinforces law's "perceptual and epistemological bias ranking vision over other senses." ${ }^{15}$ It promotes and upholds legal ocularcentrism. ${ }^{316}$ This raises concerns about audiovisualization and multisensorization in our digital world. I will return to this point.

305 Douzinas and Nead, 11.

306 According to Röhl, "stehen die Massenmedien als der wichtigste Schauplatz der Kommunikation über Recht im Vordergrund" ["the mass media are the most important site of communication about the law" (Röhl, "Das Recht im Zeichen der Globalisierung," 79).

307 See, e.g., Gies, "The media and public understanding of the law," 65. Gies does not specifically refer to images of law in the media, but to legal and legally relevant contents in the media in general. Saying that, her observations also apply to images of law. See also Friedman, "Law, Lawyers, and Popular Culture," 1588.

308 Silbey, "Images in/of Law," 179.

309 Silbey, "Images in/of Law," 179.

310 See, e.g., Gies, 65.

311 See, e.g., Silbey, "Images in/of Law," 179-80. On how images affect popular legal culture, see also Baer, 79-80, marginal numbers 87-89.

312 Sherwin, When Law Goes Pop, 7.

313 Bently, "Introduction," 2.

314 Similarly, see, e.g., Hamilton, Majury, Moore, and Sargent, „Sensing law,“ 9.

315 Oxford Reference, "Overview: ocularcentrism."

316 On law's ocularcentrism, see, e.g., Bently, 3-12. 


\section{Legal Design}

\subsection{Subject matter}

It is impossible to determine the subject matter of legal design (its key concept and prototypical situation) without referring to design research.

Maldonado, a renowned design theorist, maintains that the term "design" is becoming increasingly fuzzy and vague. ${ }^{317}$ In his keynote at the 2011 "INTERACTIONeleven" conference, ${ }^{318}$ Buchanan, a well-known professor of design theory, practices, and entrepreneurship, ${ }^{319}$ observed: "Design has no subject matter." ${ }^{320} \mathrm{He}$ later commented: "We make our subject matter." ${ }^{211}$ Thus, does legal design have no subject matter either? Do we also make legal design's subject matter? And who is "we"?

\section{WHAT IS IT?}

\section{Subject matter \\ - Key concept \\ - Prototypical situation}

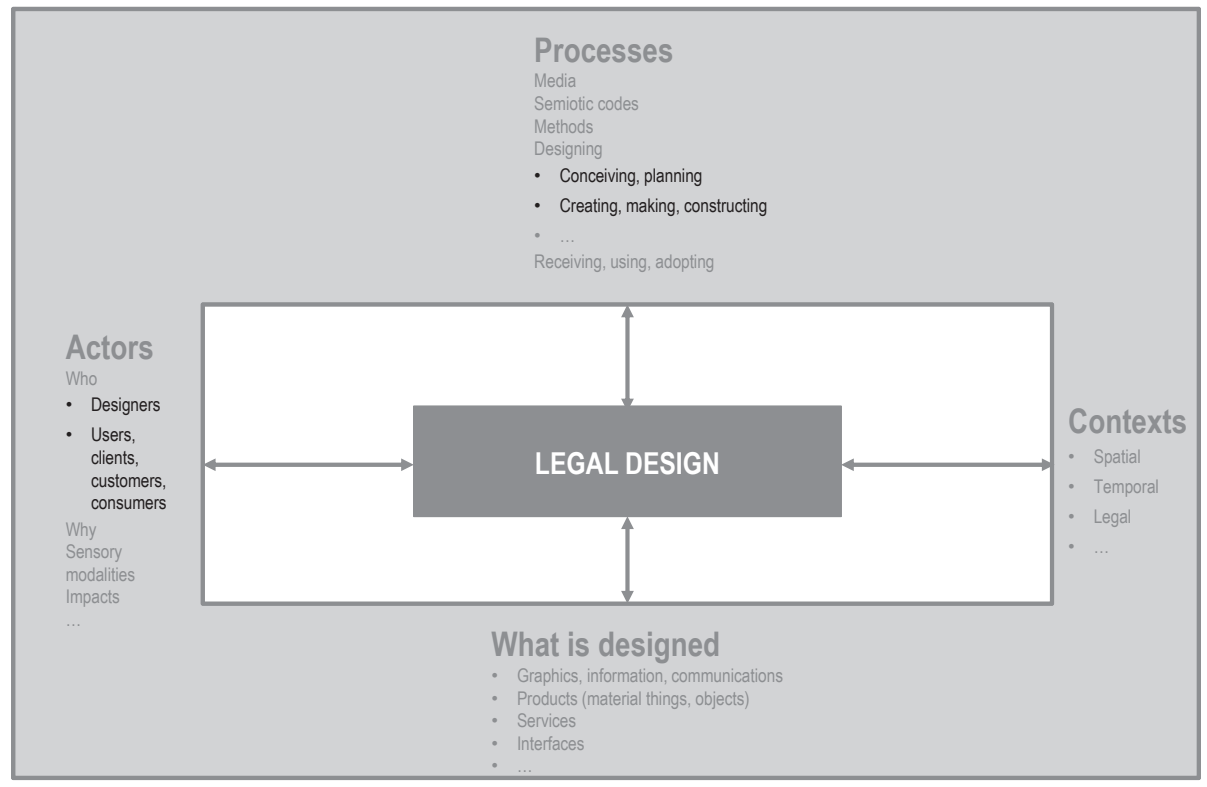

Figure 8

Notwithstanding Buchanan's assertions, I would argue that "legal design" is both process and product (i.e., what is designed during this process, something that refers to law or is related to law).

The prototypical situation of legal design consists of four characteristic components: processes, products, actors, and contexts.

317 See Maldonado, Digitale Welt und Gestaltung, 368.

318 IxDA and Digital Works, "INTERACTION eleven, February 9 - 12 : Boulder Colorado"; Woody, [中文字幕]IxD 11_Richard Buchanan_4 order of design_交互設計的四個維度 5:09-10.

319 See Case Western Reserve University, Weatherhead School of Management, "Faculty - Richard Buchanan."

320 Woody, [中文字幕]IxD 11_Richard Buchanan_4 order of design_交互設計的四個維度, 5:09-5:10, 5:20. Similarly, see Buchanan, "Rhetoric, Humanism, and Design," 24.

321 Woody, [中文字幕]IxD 11_Richard Buchanan_4 order of design_交互設計的四個維度, 5:24-25. Similarly, see Buchanan, “Rhetoric, Humanism, and Design," 24. 
- Processes:

- Which media (analog or digital) are used to design communicative contents, products, services, interfaces, etc.?

- Which semiotic codes does such design involve?

- Which design methods are used? In communication design, this would include visual rhetoric. ${ }^{322}$

- Actors:

- Who is a legal designer: legal professionals, law students, lay persons (e.g., illustrators, designers, computer scientists, or even humanoid robots)? Whom do legal designers act for? Design studies calls such actors users, clients, customers, and consumers.

- Why are information, products, services, interfaces, etc. designed (reasons and purposes)?

- Which sensory modalities (e.g., vision and touch) does the design process or receiving, using, or adopting what is designed involve?

- How does legal design impact designers and their users, clients, customers, or consumers?

- What is designed? Tangible (i.e., material or immaterial) output (e.g., graphics, ${ }^{323}$ information, ${ }^{324}$ communications, (industrial) products, ${ }^{325}$ services,${ }^{326}$ interfaces, etc).

- Contexts: In which contexts does legal design play a role? In the legal context, relevant spheres include legal research, legal education, legal practice, and legislation.

\subsection{Subareas and the micro-, meso-, and macro-level}

As mentioned, the term "legal design" is increasingly fuzzy and vague. It is neither clear which subareas it encompasses nor which societal levels it is relevant to. Some suggestions are therefore warranted. The insights of design research ${ }^{327}$ suggest how legal design might be subdivided. Figure 9 proposes, for instance, graphic design, product design, service design, interaction design, software design, and architectural design as important subareas (see left side). The right side indicates which societal contexts or rather levels are at stake: the micro-, meso-, and macro-level.

\footnotetext{
322 See, e.g., Buchanan, "Design Research and the New Learning," 10. On the design process, see also Hagan, "Legal Design as a Thing," 6-13.

323 Similarly, see, e.g., Buchanan, "Rhetoric, Humanism, and Design," 45.

324 See, e.g., Buchanan, "Design Research and the New Learning," 7.

325 See, e.g., Buchanan, "Rhetoric, Humanism, and Design," 45; id., "Design Research and the New Learning," 7.

326 See, e.g., Buchanan, "Rhetoric, Humanism, and Design," 45; id., "Design Research and the New Learning," 7.

327 See, e.g., Burkhard, "Tendencies of German Design Theories in the Past Fifteen Years," 49. On graphic, information, or communication design as a subarea of design studies, see, e.g., Buchanan, "Design Research and the New Learning," 8, 10; id., "Human Dignity and Human Rights," 38. On product design as a subarea of design studies, see, e.g., Buchanan, "Human Dignity and Human Rights," 38; id., "Design Research and the New Learning," 10. On interaction design as a subarea of design studies, see, e.g., Buchanan, "Design Research and the New Learning," 11.
} 


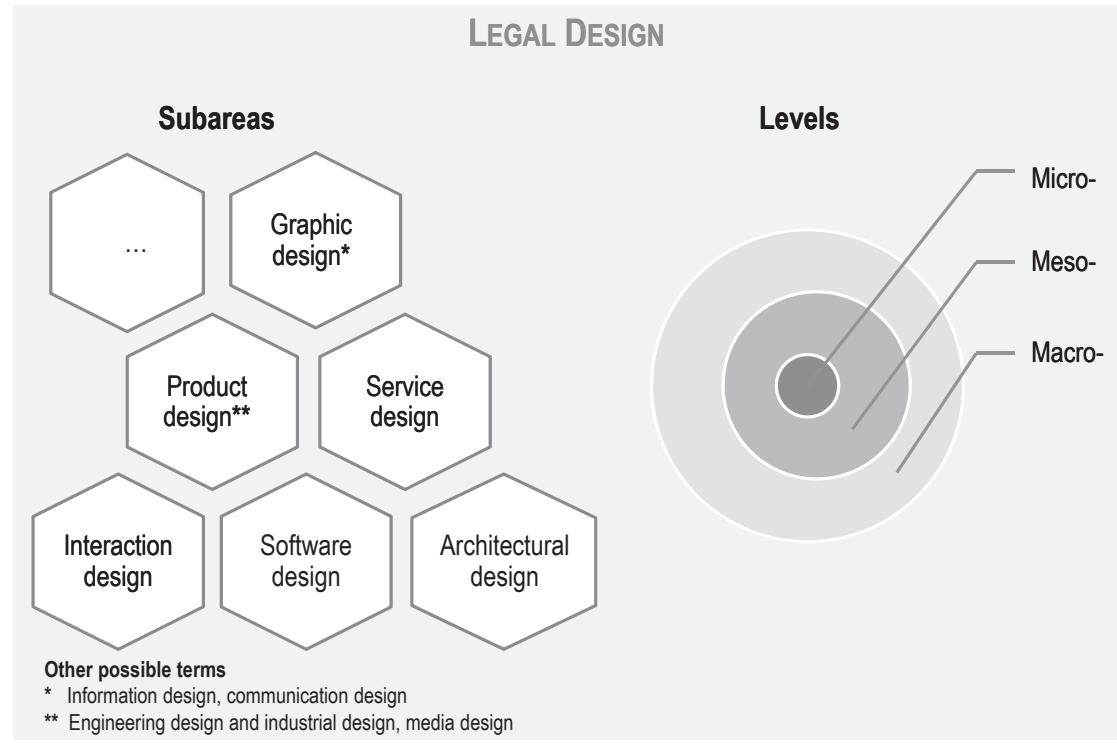

Figure 9

Building on these insights, I suggest that the subareas of legal design include: legal graphic design, legal product design, legal service design, legal interaction design, legal software design, ${ }^{328}$ legal architectural design, ${ }^{329}$ and so on. Other possible terms for graphic design include information design ${ }^{330}$ or communication design. The term "product design" also invokes "engineering design" and "industrial design." 331

Design, and thus also legal design, can occur on a micro-, meso-, and macro-level. Hence, legal designers are "socially located actors." 332 What does this mean? "[T] he micro-level involves individuals acting out of their own states of agency and their interactions with other individuals." ${ }^{333}$ The meso-level refers to "organizations or corporate actors." 334 The macro-level encompasses "society as a whole" 335 and "large-scale social structures and institutions." $" 336$ If legal designers act on their own or interact with other legal actors or laypersons, they are working on the micro-level. If legal designers act as employees or mandatees of organizations (e.g., industry, banks, insurance companies), they do so on the meso-level. ${ }^{337}$ The same applies to legal designers employed by public authorities (e.g., administrative agencies, governments, courts). If the state as a whole, or the legal system, committed to legal design, they would do so on the macro-level. ${ }^{338}$ The boundaries between these three levels are fluid.

\footnotetext{
328 See, e.g., Perry-Kessaris, 186. Legal software design is also a branch of legal design. Lawyers work with legal software (e.g., case managment software, litigation support software, trial presentation software, document management software). Legal software design interfaces with legal informatics (tools or media, methods or, to use a "hype" term, legal tech).

329 Legal architectural design is also a branch of legal design. It deals with designing legal or legally relevant buildings: court houses, parliament buildings, administrative buildings, prisons, law offices, law libraries, etc.

330 See, e.g., Passini, "Information Design," 83-85.

331 See, e.g., Ulrich and Eppinger, Product Design and Development, 3.

332 Little, "Explanatory Autonomy and Coleman's Boat," 137.

333 Little, 137. Similarly, see Preisendörfer, Organisationssoziologie, 154.

334 Original citation: to "Organisationen bzw. korporativen Akteuren" (Preisendörfer, 154).

335 Original citation: "Gesamtgesellschaft" (Preisendörfer, 154).

336 Ritzer, "The Rise of Micro-Sociological Theory," 88.

337 See, e.g., Preisendörfer, 155.

338 See, e.g., Santuber, Krawietz, Owoyele, and Edelman, 51-55.
} 
Let me cite d'Anjou's apt views on design's subareas and its association with various non-design disciplines:

In a broad sense, design refers to those disciplines involved in changing existing states of affairs into preferred ones. It concerns not only disciplines like architecture, urban design, interior design, graphic design, and industrial design, to name a few, commonly associated to design but also others like medicine, engineering, law, etc., that are equally engaged with the purpose of making a difference in and changing the state of the world. 339

The subareas of design studies have particular subject matters. These, in turn, relate to the subject matter of legal design. Below, I comment merely briefly on legal communication design, legal product design, and legal service design. There is no room to consider legal interaction design, ${ }^{340}$ legal software design, ${ }^{341}$ and legal architectural design. ${ }^{342}$

\subsection{Legal communication design}

As early as 1936, Rodell lamented that two things were "wrong with almost all legal writing. One is its style. The other is its content." ${ }^{343}$ Inspired by models that represent the domains of graphic, information, and communication design, ${ }^{344}$ I would describe legal communication design as a field that tackles not only the problem of style observed by Rodell but also that of typography, layout, and the lack of images in legal communication. ${ }^{345}$

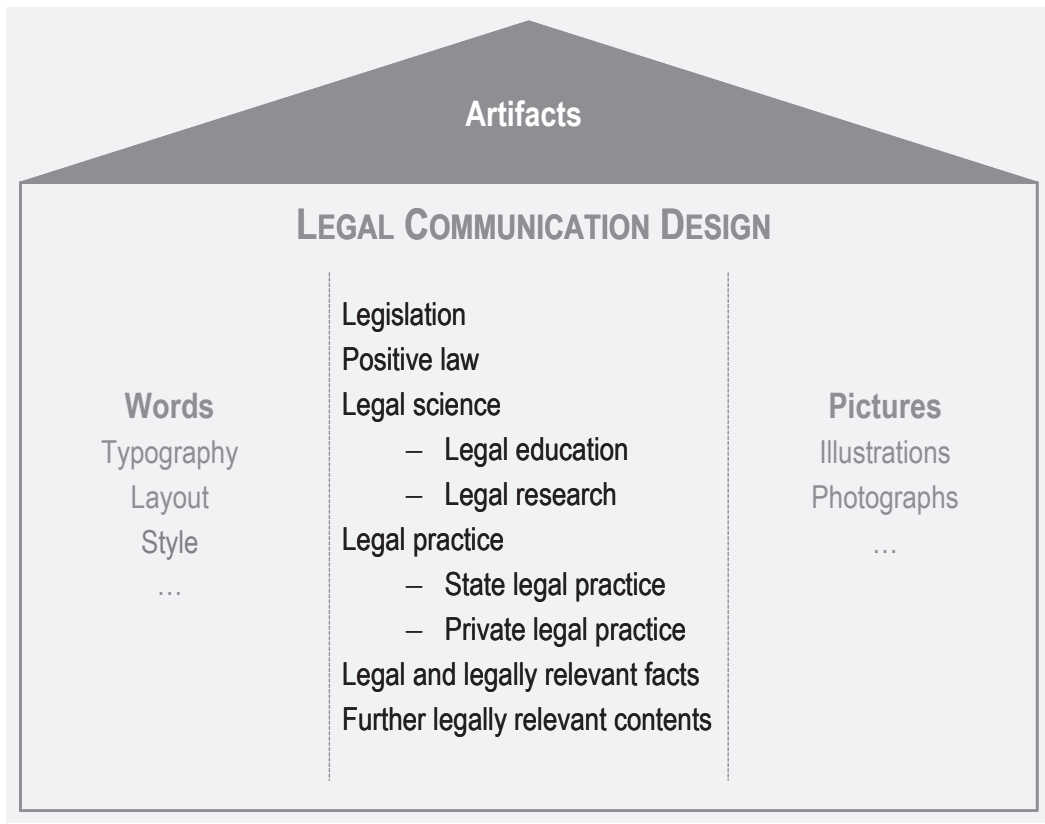

Figure 10

\footnotetext{
339 D'Anjou, Design Ethics beyond Duty and Virtue, 1.

340 On interaction design, see, e.g., Crampton Smith, "Foreword," vii-xi.

341 On (legal) software design, see, e.g., Martin, Clean Architecture; Fenwick, Kaal, and Vermeulen, "Legal Education in a Digital Age," $103-22$.

342 Instead, see Mulcahy, Legal Architecture; Mulcahy and Rowden, The Democratic Courthouse.

343 Rodell, "Good Bye to Law Reviews," 38.

344 See, e.g., Harland, "The Dimensions of Graphic Design and Its Spheres of Influence," 21-22, 25-26, 29-32.

345 See, e.g., Santuber, Krawietz, Owoyele, and Edelman, 44. See also Perry-Kessaris, 194.
} 
Legal communication designers produce verbal and visual artifacts that concern various issues: legislation, positive law, legal science (including legal education and legal research); the practices of courts, governments, and government agencies; private legal practice (e.g., the lawyering offered by law firms and by inhouse counsels); legal and legally relevant facts; other legally relevant contents.

\subsection{Legal product design}

From a design perspective, "a product is usually understood to be a physical object [...]." ${ }^{346}$ If it is a digital object, it is hardware. However, the term "product" also includes software. According to product design experts Ulrich and Eppinger, product design defines "the physical form of the product to best meet customer needs." 347 Within this setting, "the design function includes engineering design (mechanical, electrical, software, etc.) and industrial design (aesthetics, ergonomics, user interfaces)." ${ }^{348}$ Engineers and industrial designers perform this function. ${ }^{349}$ This raises the question whether we ought to imagine legal actors as "engineers" and "industrial designers." I believe we should, at least to some extent. Why?

\section{Legal Product Design}

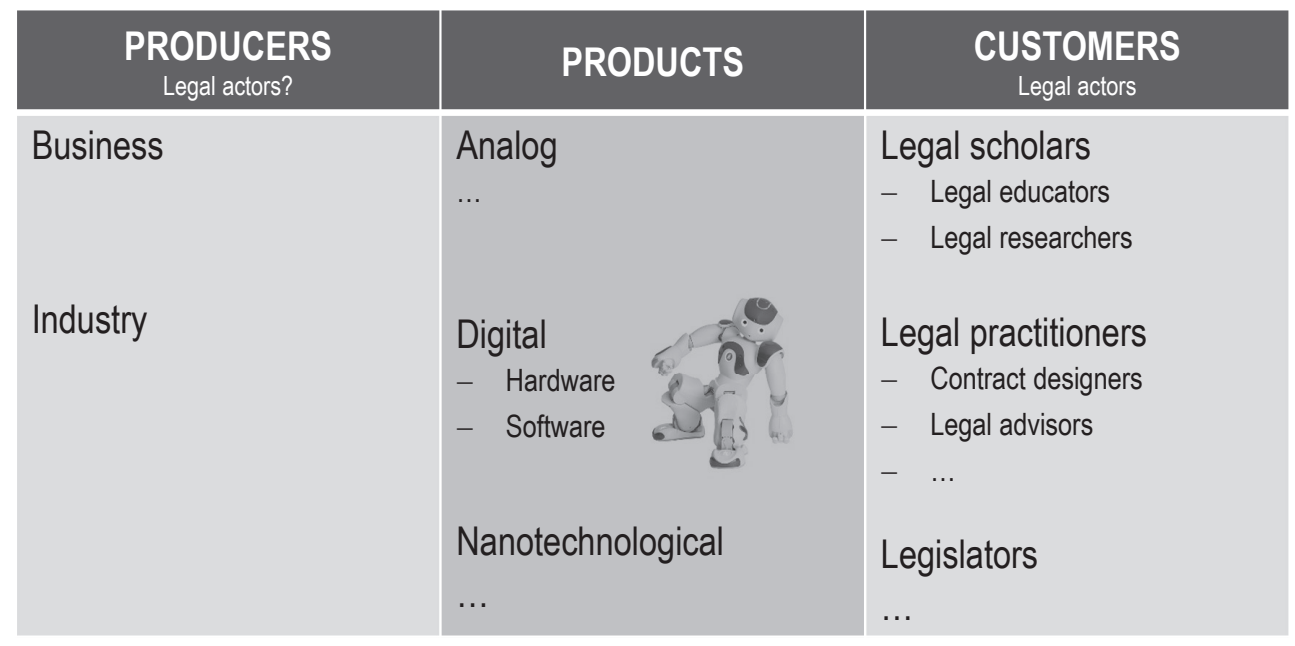

Figure $11^{350}$

\footnotetext{
346 Buchanan, "Design Research and the New Learning," 10.

347 Ulrich and Eppinger, 3.

348 Ulrich and Eppinger, 3.

349 See, e.g., Ulrich and Eppinger, 4.

350 Figure 11, includes the image of a NAO Robot: https://upload.wikimedia.org/wikipedia/commons/7/79/NAO_Robot_.jpg (last accessed November 30, 2020; the image is in the public domain).
} 
Legal product design interfaces with legal informatics. Legal informatics addresses IT-related legal problems (legal-doctrinal focus) and transposes the insights of informatics to the legal context (interdisciplinary focus). ${ }^{351}$ Legal information scientists develop and teach basic hardware and software knowledge and skills (tools and methods). As such, legal informatics focuses on digital legal products, that is, digital legal technology (e.g., the automated drafting of legal documents, such as contracts, wills, or bylaws). ${ }^{352}$ There is an ongoing debate on the informatics knowledge and skills that legal information scientists should acquire. ${ }^{353}$ In today's digital world, this question also applies to lawyers. Fenwick, Kaal, and Vermeulen claim that "In the digital world, [...] lawyers will not only have to work closely with their traditional professional partners such as accountants or financial advisors but also with engineers, designers, architects and other technical experts and specialists (depending on the particular project/transaction)." ${ }^{354}$ Hence, the insights of legal product design might very well enrich interdisciplinary legal informatics in the future - and vice versa, of course.

Looking ahead to visualization, audiovisualization, and multisensorization: Should lawyers be able to code legal databases containing visualizations and audiovisualizations? Should legal actors know how to code the software of humanoid robots for the purposes of legal education or visual legal persuasion? Do they need this knowledge to work in a virtual reality law firm?

\subsection{Legal service design}

Legal services are provided by lawyers or other legal actors to clients. ${ }^{355}$ These actors can be natural persons or "intelligent machines" 356 (e.g., humanoid robots). Navas claims that artificial systems such as humanoid robots do not provide legal services but automatically create legal products. ${ }^{357}$ Thus, legal services and legal products are now even harder to distinguish. ${ }^{358}$ Her assertion not only contradicts the design discourse but also the discourse of service management, which basically upholds this distinction. ${ }^{359}$

351 Erdelez and O’Hare, "Legal Informatics: Application of Information Technology in Law," 367.

352 See, e.g., Navas, "The Provision of Legal Services to Consumers Using LawTech Tools," 80.

353 See, e.g., Fenwick, Kaal, and Vermeulen, 105.

354 Fenwick, Kaal, and Vermeulen, 109.

355 See also the entry on "legal services" in the Cambridge Dictionary.

356 Navas, 82.

357 See Navas, 83-84.

358 On the difficulty of distinguishing material goods and services (immaterial or intangible goods), see, e.g., Haller, Dienstleistungsmanagement, 7-8.

359 See, e.g., Haller, 8-14. 


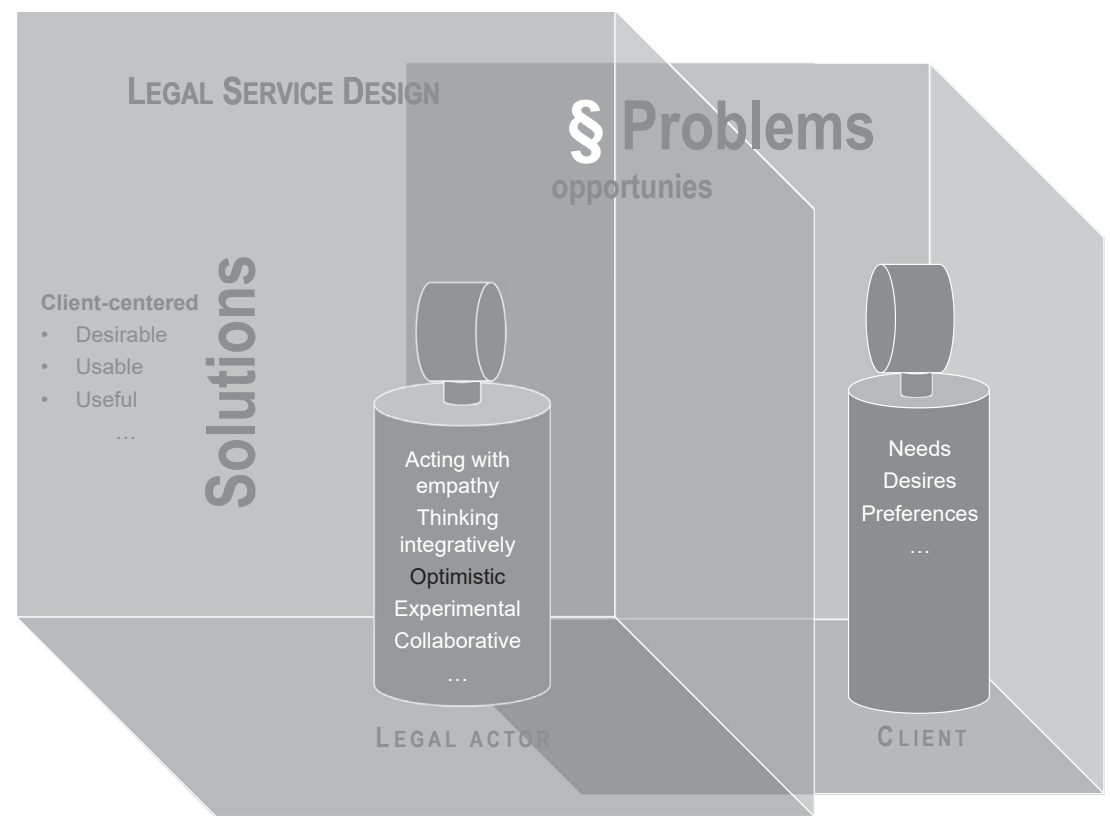

Figure 12

Legal services are provided in the private and public sector. In the private sector, lawyers offer clients advice and guidance on their rights and duties (provision of legal information as part of legal counseling). Other tasks include reviewing legal documents (e.g., contracts, wills, and bylaws) and representing clients in civil and public law cases. In the public sector, and from the perspective of public management, the state also renders legal services: For example, courts, governments, and administrative agencies offer legal information; notary offices certify contracts; universities as state-funded institutions provide legal education and conduct research. But what happens when the insights of design impact legal services?

Figure 12 (see above) depicts the prototypical situation of legal service design and its characteristic components. ${ }^{360}$ For clients, problems ${ }^{361}$ and opportunities ${ }^{362}$ are at stake. In applying the insights of design, legal actors think and feel in a client-centered way ${ }^{363}$ and approach their clients' concerns in a solution-oriented manner. Legal design theory distinguishes a problem and a solution space. ${ }^{364}$ Lawyers, for example, focus on their clients' needs, ${ }^{365}$ desires, ${ }^{366}$ and preferences. ${ }^{367}$ Their services are desirable, ${ }^{368}$ usable, ${ }^{369}$ and useful. ${ }^{370}$ My model (Figure 12) integrates the ideal traits of (legal) service providers.

Have you ever met a lawyer who was genuinely optimistic about winning a case? All $I$ have ever heard is: "I can't promise or guarantee anything" (or "the outcome depends on X, Y, and Z"). From a design perspective,

\footnotetext{
360 See Krapp, Prenzel, and Weidenmann, 24-27.

361 See, e.g., Brown, "Design Thinking," 88, 92; Brown and Katz, "Change by Design," 381.

362 See, e.g., Brown, 88.

363 Design and hence legal service design must be human-, i.e., client-centered (see Figure 12).

364 See, e.g., Santuber, Krawietz, Owoyele, and Edelman, 53.

365 See, e.g., Brown, 86, 92; Perry-Kessaris, 197.

366 See, e.g., Brown, 86, 92.

367 See, e.g., Brown, 90.

368 Buchanan, "Design Research and the New Learning," 13.

369 Buchanan, "Design Research and the New Learning," 13.

370 Buchanan, "Design Research and the New Learning," 13.
} 
state-funded research (e.g., research conducted at public universities), which-I repeat—could be viewed as a legal service, meets or should meet the needs, desires, preferences of the general public. Besides, such research is or should be desirable, useful, and usable. In this way, design discourse might productively intervene in the debate over academic freedom and the relevance of research for society, business, and industry. Regarding legal services in the public sector, design and particularly legal service design become additional dimensions in the discourse on public management where the dimensions of law, economics, political science, and other related fields are already playing an important role.

\section{Visual Law and Legal Design: Similarities and Differences}

Both visual law and visual legal communication design or produce visualizations. The contents of these visualizations are normative, factual, or both. The actors, their aims, and their action contexts are similar.

\section{SIMILARITIES AND DIFFERENCES}

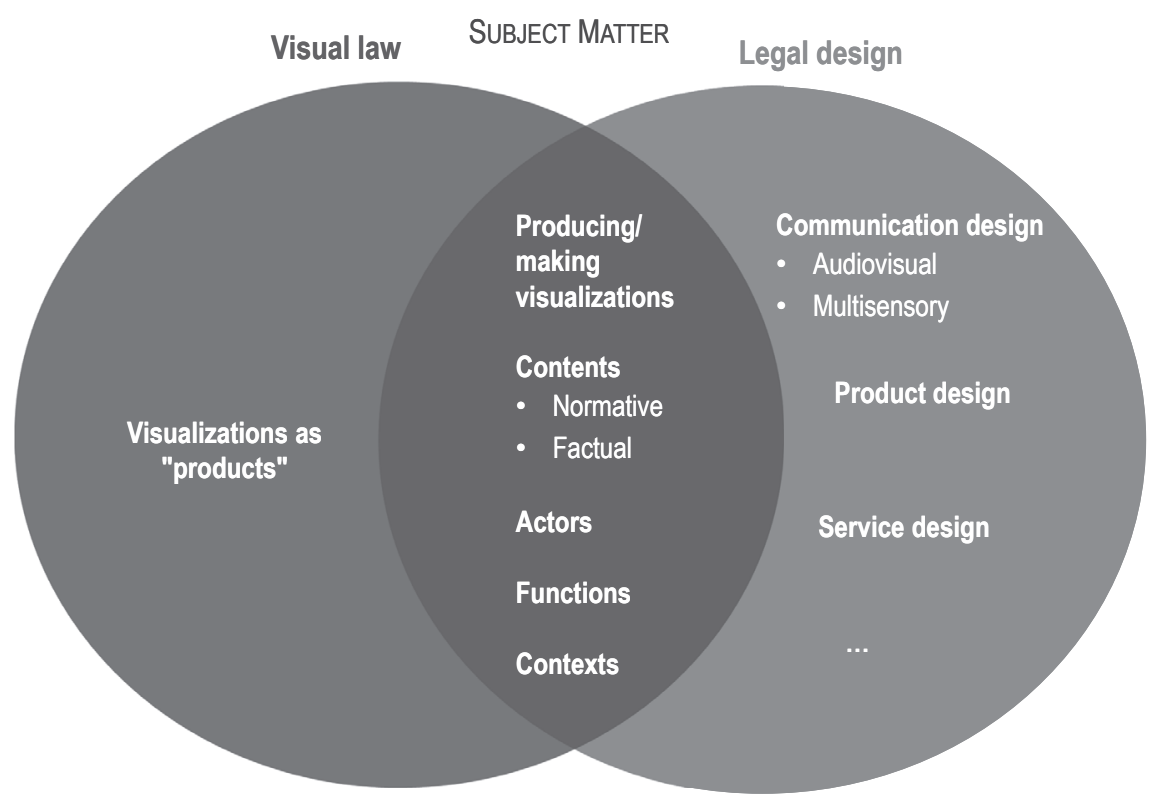

Figure 13

Despite the similarities between visual law and legal design, several differences are worth noting. Whereas visual law focuses on production and products, legal design mainly focuses on producing. ${ }^{371}$ As d'Anjou observes:

Science sees the world as an object to be observed, understood, and known whereas design sees the world as a project to be transformed, invented, and brought into existence. Science seeks what is out there and design creates what ought to be here. Science pretends to objectivity, design accepts subjectivity. Design, as a mode of human inquiry and practice, is concerned with bringing into existence, through projecting, making, and transforming, an artificial world in terms of both material and immaterial domains. ${ }^{372}$

371 See, e.g., Passini, 86.

372 D'Anjou, 1; original emphases. Similarly, see, e.g., Newcomb, "Sustainability as a Design Principle for Composition," 594. 
Contrary to Anglo-American scholarship, I maintain that visual law is limited to visualization. ${ }^{373}$ US and British scholars subsume visual and audiovisual legal phenomena under visual law. But audiovisual law (which is also a working term like "visual law") concerns (or at least ought to concern) audiovisualization (e.g., videos, movies, audiovisual animations). Legal audiovisuals require visual and auditory media or rather multimedia (mediality), involve visual and acoustic signs (codality), and address sight and hearing (modality). These basic factors have consequences for visualization as a process and visualizations as products or productions. For instance, the methodological requirements for interpreting legal visuals differ from those needed to interpret legal audiovisuals. Multisensory law (also a working term) concerns multisensorization (e.g., humanoid robots and virtual realities).

From a legal design perspective, the audiovisual and multisensory design of legal communication lies beyond the interface between visual law and legal design. The same is true of legal product design, legal service design, and probably legal interface design. Designing legal products, and therefore their design (e.g., virtual realities and humanoid robots), is per se multisensory.

\section{Visual Lawyers, Legal Designers, and Responsible Digitalization}

We have thus far considered how visual law and legal design respond (or rather do not respond) to visualization, audiovisualization, and multisensorization.

Thus, in terms of responsible digitalization, the topic of the International Legal Informatics Symposium 2020, how should visual lawyers and legal designers correspond to law, ${ }^{374}$ professional standards, and digital (legal) ethics? According to Mitcham, "The most fundamental ethical question concerning design is this: To what extent is this new way of being in the world desirable or good?" ${ }^{775}$ Based on this and other questions, design research establishes human-centered criteria, regardless of whether communication, product design, or service design is concerned. ${ }^{376}$ As such, design must fit "the human body and mind." 377 Buchanan maintains that "design has a more important role to play in promoting human well-being [than just pragmatically oriented design; my insertion]." ${ }^{378}$ More specifically, what is designed must be needed, ${ }^{379}$ desirable, ${ }^{380}$ or at least preferable. ${ }^{381}$ It ought to be usable, ${ }^{382}$ useful (functionality), ${ }^{383}$ and sustainable. Klein and Phillips argue that traditionally "sustainability calls for policies and strategies that meet society's present needs without compromising the ability of future generations to meet their own needs." 384 Sustainable design refers particu-

373 See, e.g., Feigenson and Spiesel, 1-34, 131-62; Bainbridge, "Visual Law," 194-95, 211-12; Sherwin, Visualizing Law in the Age of the Digital Baroque, 1-12, 13-55.

374 See, e.g., Orel, "Designing Self-Diagnostic, Self-Cure, Self-Enhancing, and Self-Fashioning Devices," 97-99.

375 Mitcham, "Ethics into Design," 179.

376 On human-centered design, see, e.g., Cooley, "Human-Centered Design," 64-70; Buchanan, "Human Dignity and Human Rights," 37; Brown, 86, 89-90; Norman, The Design of Everyday Things, 8-9.

377 Buchanan, "Human Dignity and Human Rights," 37.

378 Buchanan, "Rhetoric, Humanism, and Design," 53. Similarly, see, e.g., Santuber, Krawietz, Owoyele, and Edelman, 48. That reminds me of therapeutic jurisprudence (TJ). Its agenda "looks at the traditionally underappreciated area of the law's impact on emotional life and psychological well-being" (Wexler, "Two Decades of Therapeutic Jurisprudence," 20). It would be interesting to explore how (legal) design and TJ might benefit from one another's insights.

379 See, e.g., Coates and Ellison, An introduction to information design, 28; Norman, 8-9.

380 See, e.g., Buchanan, "Design Research and the New Learning," 13; Klein and Phillips, "Sustainable Design," 75.

381 See, e.g., Koyama and Igarashi, "Computational Design with Crowds," 161.

382 See, e.g., Buchanan, "Design Research and the New Learning," 13; Lipton, The Practical Guide to Information Design, $37-87$.

383 See, e.g., Buchanan, "Design Research and the New Learning," 13; Lidwell, Holden, and Butler, Universal Principles of Design, 12 , 16.

384 Klein and Phillips, 69. 
larly to the impacts of the designed communication, products, ${ }^{385}$ and services ${ }^{386}$ on ecology, ${ }^{387}$ society, ${ }^{388}$ the economy, ${ }^{389}$ technology, ${ }^{390}$ and health. ${ }^{391}$ Product design, for instance, should create artifacts that are not only socially, ${ }^{392}$ economically, and ecologically ${ }^{393}$ sustainable, ${ }^{394}$ but also technologically. ${ }^{395}$ Regarding technological sustainability, humanoid robots deployed in legal education, for contract visualization, or other legal purposes, would need to be maintained, repaired, and replaced. In terms of social sustainabilty, such robots would need to be designed so as to positively affect individuals and society. ${ }^{396}$

\section{RESPONSIBLE DIGITALIZATION}

CORRESPONDING TO LAW, PROFESSIONAL STANDARDS, AND DIGITAL LEGAL ETHICS

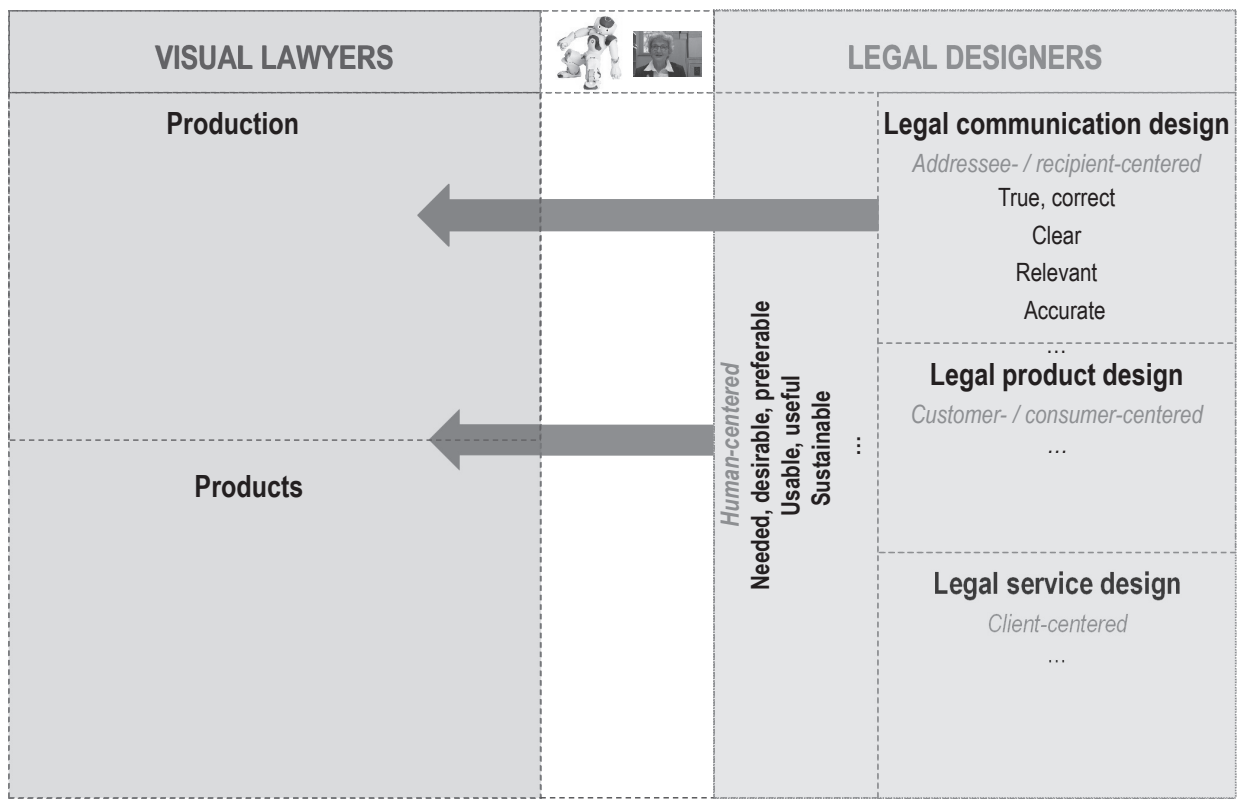

Figure $14^{397}$

385 See, e.g., Klein and Phillips, 69

386 See, e.g., Klein and Phillips, 70.

387 On ecological sustainability in design in general, see, e.g., Maldonado, 373.

388 On social sustainability in design in general, see, e.g., Maldonado, 374. On social sustainability in product design, see, e.g., Klein and Phillips, 70.

389 The term "recipient" is used to designate the "addressees" of legal information. See, e.g., Jacobson, "Introduction," 2

390 See, e.g., Klein and Phillips, 69-73.

391 See, e.g., Klein and Phillips, 70.

392 On ecological sustainability, particularly in product design, see, e.g., Klein and Phillips, 70-75.

393 See, e.g., Klein and Phillips, 70-75.

394 On the concept of sustainability, see Adams, The Future of Sustainability.

395 See, e.g., Klein and Phillips, 70-75.

396 See, e.g., Klein and Phillips, 75.

397 In addition to an image of my humble self as a visual lawyer and legal designer, Figure 14 contains an image of a NAO Robot: https:// upload.wikimedia.org/wikipedia/commons/7/79/NAO_Robot_.jpg (last accessed November 30, 2020) and of my humble self (2017). This image is in the public domain. 
Legal communication design needs to be addressee- or recipient-centered. ${ }^{398}$ Thus, verbally, verbo-visually, or visually designed communication should be true, correct, ${ }^{399}$ clear, ${ }^{400}$ relevant, ${ }^{401}$ accurate, ${ }^{402}$ and appropriate. ${ }^{403}$ Accordingly, when they produce legal visualizations, visual lawyers also ought to comply with these criteria. Beyond satisfying ethical requirements, visual and verbo-visual legal information should also be aesthetically pleasing. ${ }^{404}$

\section{Findings, Conclusions, and Outlook}

\subsection{Response of legal scholarship to visualization}

According to Posner, "[d] octrinal scholarship continues [...] to dominate legal scholarship." 405 Thus, this kind of scholarship does not explore visualization, audiovisualization, and multisensorization, unless doctrinal questions are concerned.
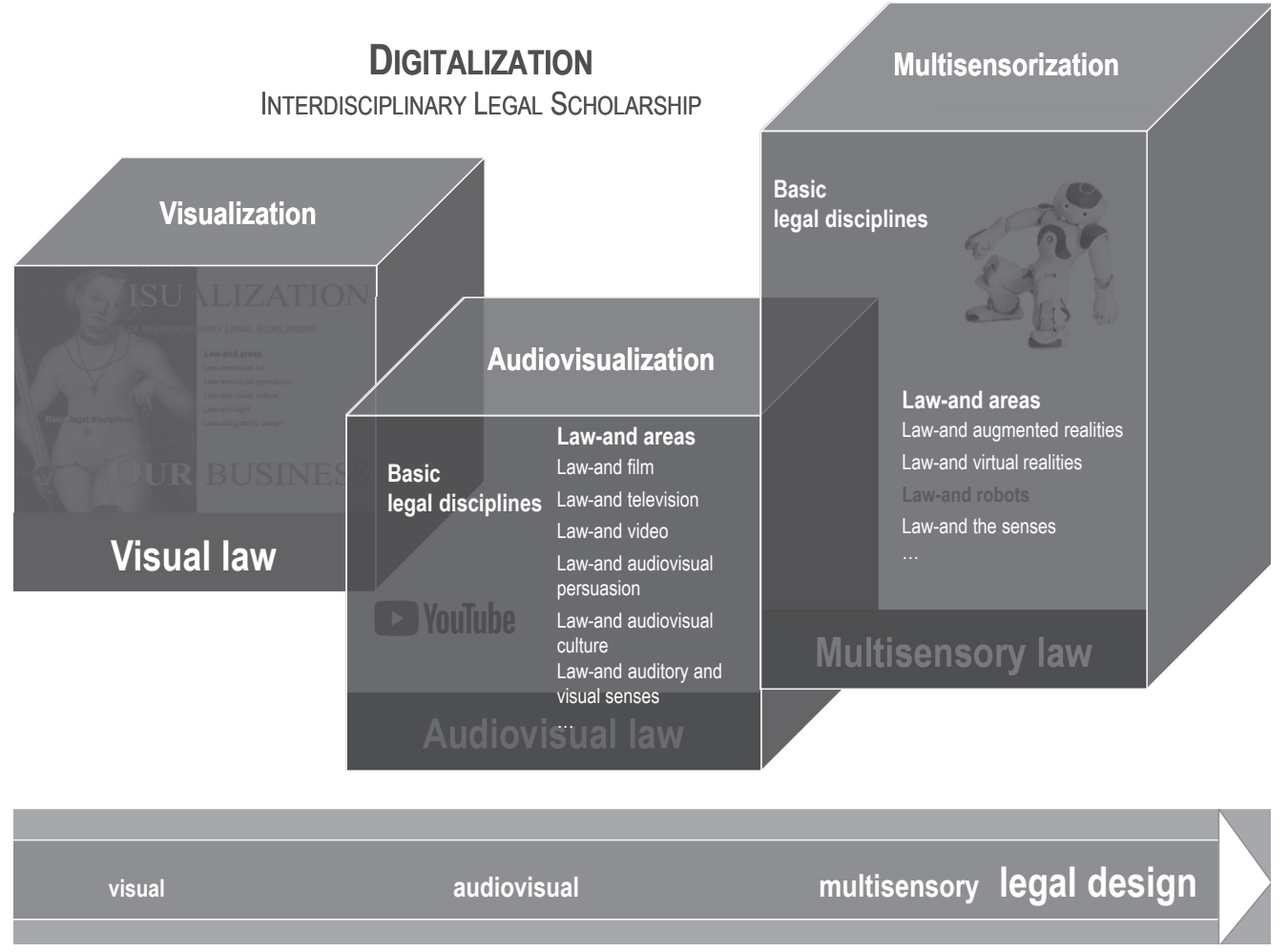

Figure 15

\footnotetext{
398 See, e.g., Pettersson, Information Design, 45.

399 See, e.g., Horn, "Information Design," 15; Pettersson, 105; Götters, Einführung in die Stilistik, 125-28.

400 See, e.g., Götters, 128-31.

401 See, e.g., Passini, 89; Lidwell, Holden, and Butler, 16.

402 See, e.g., Langer, Schulz von Thun, and Tausch, Sich verständlich ausdrücken, 21, 32-33.

403 See, e.g., Götters, 150-51.

404 See, e.g., Horn, 15; Passini, 87.

405 Posner, 1317. See also Rhode, 1339; Martyn and Huygebaert, 7.
} 
Levinson has called upon law to free itself "from the iron cage of doctrinal analysis and be willing to look to other approaches [...]." 406 These include, as I have suggested, visual law and visual legal communication design. Figure 15, however, suggests that while the two fields deal with visualization, they do not cover audiovisualization and multisensorization. ${ }^{407}$ Once again, these are the domains of the basic legal disciplines and specific law-and areas (see Figure 15).

Visual, audiovisual, and ultimately multisensory interdisciplinary research "enrich[es] the study of legal issues, $[\ldots] . "{ }^{408}$ Since this research is multidimensional, its scholars strive "to advance and promote improvement of their profession and its institutions." 409 Without any problems, such research can be "subjected to the test of relevance, or practical impact." 410 This makes it interesting not only for legal academia but also for legal practitioners (e.g., lawyers, judges, public servants) and legislators. Multisensory interdisciplinary research is not anti-doctrinal but aware of its own interfaces with doctrinal legal scholarship. For instance, legal norms cannot be visualized or audiovisualized without considering their interpretation by legal doctrine. In this light, interdisciplinary legal research on visualization, audiovisualization, and multisensorization needs more recognition, including more institutional and financial support. Considering this aspect, Epstein notes that "the structure of the academic legal marketplace exerts a powerful influence on the nature and direction of legal scholarship. The largest returns from scholarship rightly belong to those individuals who break the traditional mold and find genuinely new ways of analyzing legal materials." ${ }^{411} \mathrm{He}$ adds, highly appropriately, that we "are becoming more and more a designed and a designing society" 412 —and, as I wish to add, also a visualizing, audiovisualizing, and multisensorizing digital society.

Although digitalization is rapidy advancing, it is unclear how long visual, audiovisual, and multisensory interdisciplinary legal scholarship will take to adopt the insights of the relevant non-legal disciplines. Once more, Epstein wisely observes that, in the past as much as today, "intellectual developments from other disciplines have taken time to work themselves sensibly into the fabric of law. Sorting out the useful from the curious, erroneous or irrelevant takes time." 413 It remains to be seen how interdisciplinary legal scholarship on visualization, audiovisualization, and multisensorization will evolve. Its development can be expected to depend on the level of funding and institutional recognition.

\subsection{Visual law and legal design}

Legal academia is likely to challenge my outline of visual law and legal design. Even Buchanan, a strong advocate of design as rhetoric, ${ }^{414}$ is still pondering the nature of design. ${ }^{415}$

For the time being, I suggest we continue using "visual law" and "legal design" as working terms. More research is required to clearly delineate these areas. To interpret legal visualizations, we need to borrow insights from disciplines that have already developed a visual hermeneutics: humanities scholarship (e.g., iconography, learning psychology) and social sciences scholarship (e.g., educational psychology). Porter suggests that courts "should develop interpretative traditions" 416 for legal visualizations. Almog has extended this notion by suggesting that the "law will have to acknowledge the shifts in visual cognizance entailed by the

\footnotetext{
406 Levinson, "Democracy in a New America," 1564.

407 On multisensory product design, see, e.g., Zaccai, “Art and Technology," 10-12.

408 Rhode, 1329.

409 Rhode, 1330.

410 Posner, 1326.

411 Epstein, 1303.

412 Dilnot, "The State of Design History, Part I.," 214.

413 Epstein, 1290.

414 See, e.g., Joost, “Audio-visuelle Rhetorik und Informationsdesign,” 213-14.

415 See Buchanan, "Design Research and the New Learning," 17.

416 Porter, 1777.
} 
digital condition." 417 Thus, the knowledge and know-how of the basic legal disciplines will need to be linked to the law-and areas dealing with visualization. These areas will thus cross-fertilize each other and advance more smoothly as their topical, methodological, and theoretical spectrum becomes enhanced at their newly emerging interface. Visual law allows us to look at visualization from the perspective of various basic legal disciplines and law-and areas. These are bound to broaden the horizon of legal visualization, not only as a practice but also as a subject of scholarly inquiry.

To outline legal design, I have drawn mainly on insights of design studies and, in part, on perceptions of legal design studies. It would be interesting to examine publications on legal design as to whether and, if so, how they take recourse to design studies. The question about what "visual law" and "legal design" mean "is not merely a dispute about words but about subject-specific contents and thus about responsibilities and the division of labor within the basic [legal; my insertion] disciplines." ${ }^{418}$ Some day, "the need for institutionalization as an independent discipline" 419 will arise.

This perspective inevitably raises further questions: Will sight continue to dominate law? ${ }^{420}$ What would visual legal hermeneutics involve, for instance, in terms of interpreting visualizations embedded in contracts, bylaws, last wills, and so forth? So far, the "verbal discourse about drawing[s; my insertion] has remained in an unnecessarily primitive and undeveloped state. [...]." ${ }^{" 21}$ How to be a visual lawyer or a legal designer? What would we have to do to attain a "[p]rofessionalism based on knowledge and skills"422? Are visual lawyers and legal designers not merely amateurs who pretend to be professionals?

\subsection{Visual law and legal design: similarities and differences}

With respect to visualization, visual law and legal communication design (as a branch of legal design) resemble each other. Visual legal-historical studies, visual legal theory, the visual sociology of law, law-and visual art, law-and visual persuasion, law-and visual culture, law-and sight, and legal communication design are all interrelated. Delimitation sometimes proves to be difficult as visual law and legal design are subject to intra- and interdisciplinary influences. They are interconnected fields. As such, they adopt, integrate, and deploy insights from legal and non-legal disciplines. Apart from that, visual law and legal design are not congruent endeavors.

On that account, we should not play these fields off against each other. Both deserve support. Their advocates should wish that neither becomes the dominant approach to visualization. As Wagner remarks, "If new intellectual communities affirm the visual as a rejection of traditional disciplines, they lose the opportunity to build on the considerable contributions those disciplines have made to visual inquiry - even if such contributions are not central to the traditional discipline itself." ${ }^{223}$ Otherwise, legitimate research focuses would be unnecessarily limited, just as important issues would be downplayed. At the International Legal Informatics Symposium or elsewhere, I have therefore opposed "radical" visual law or "radical" legal design.

I am under no illusion that visual law and legal design are (or will be) the solutions to all problems in the legal context. I do, however, believe that both areas are (and will be) able to tackle problems and questions

417 Almog, 153.

418 Original citation: "ist kein blosser Streit um Worte, sondern um fachspezifische Inhalte und damit um Zuständigkeiten und Arbeitsteilung innerhalb der Grundlagenwissenschaften" (Kunz and Mona, 94 marginal number 196). This citation refers to legal theory. But as it applies to other scholarly areas, I am transposing it to visual law and legal design.

419 Original citation: “das Bedürfnis nach Institutionalisierung [...] als eigenständiges Fach” (Kunz and Mona, 94 marginal number 196). Here, too, I am transposing this view to visual law and legal design.

420 See, e.g., Bently, 3. On "ocularocentrism in the legal context," see, e.g., Brunschwig, "Law Is not or Must Not Be Just Verbal and Visual in the $21^{\text {st }}$ Century," 236-37.

421 Ashwin, "Drawing, Design and Semiotics," 199.

422 Margolin, "The Product Milieu and Social Action," 123

423 Wagner, 171. 
that otherwise would be dismissed. Commenting on the introduction of a new term or concepts, Passini states that this "must be fully justified if it refers to new notions, or if it signifies profound changes in established practice." 424 I see "visual law" and "legal design" as umbrella terms that suitably cover various legal and legally relevant phenomena. Potentially, these terms will lead to "profound changes in established" legal research, legal education, legal practice, and legislation.

\subsection{Visual lawyers, legal designers, and responsible digitalization}

Design research has been developing guidelines for how legal designers and, by implication, visual lawyers might act responsibly in the face of ongoing digitalization. Future research needs to work out how these guidelines relate to law and digital (legal) ethics. The question also arises how digital legal ethics could benefit from the insights of ethics (as a branch of philosophy) in general, and of legal ethics (as a branch of legal philosophy), and digital ethics (as a branch of digital philosophy) in particular.

\subsection{Concluding remarks}

I have explored how legal research has been and is responding to the growing tendency toward visualization characteristic of today's digital world. I have also outlined visual law and legal design, examined how these two areas are related (similarities and differences), and considered what visual lawyers and legal designers should do to act responsibly to digitalization.

In his textbook, Vesting, a leading German legal theorist, considers whether digitalization prompts an iconic turn in the legal context:

By constrast, it seems the diagnosis of the "visual shift" falls short. Surely, one can easily demonstrate [or identify; my insertion] a series of phenomena, which point in the direction of an "iconic turn". Richard Sherwin has depicted [or described; my insertion] the infiltration of visual popular culture into US American law, for instance, with the example of the adoption of cinematic constructions of reality in a trial by jury [rather: in jury trials; my insertion]; Cornelia Vismann observes in the [sic] Medien der Rechtssprechung a new openness of (international) courts to audiovisual digital technologies, which she interprets as permeability for $[$ sic $]$ extrajudicial demands and influences. Moreover, it is predictable that the computer will include and change the operational mode of legislation, administration, and case law in an entirely different way, a development that may be detected on the level of administration, for instance, in the recent developments of the $[s i c]$ "electronic government" and the $[s i c]$ "administrative information law". But insofar as schematic scenarios of decay of the conceptual legal culture are connected with the rise of visual media and the computer - that is, diagnoses of a visualization of juristic thought, of a "flood of images", in which the "writing culture" of law is threatened with drowning - the thesis of the [sic] visual shift is not convincing. ${ }^{425}$

If I were a law student today, I would feel discouraged by these observations, not least because they are made with the leverage of professorial authority. I would be disheartened to ever explore visualization, let alone audiovisualization and multisensorization.

It is perhaps too early to determine whether a visual, audiovisual, or even a multisensory turn is occurring in the legal context. While I agree with Vesting that the verbal code will remain the most important in legal communication, I would challenge his denial of the significance and bearing of legal visualization and audiovisualization. Thus, somewhat astonishingly, a legal theorist specializing in media theory ignores multisensorization (i.e., virtual realities and humanoid robots).

424 Passini, 83.

425 Vesting, Legal Theory, 168, marginal note 328. 
Put mildly, visualization, audiovisualization, and multisensorization are unorthodox subjects in the eyes of doctrinal legal scholarship. They are avant-garde — or indeed "hot"-topics even for interdisciplinary legal scholarship. Yet they will potentially contribute to changing how legal scholars understand "what constitutes [...] scholarship." 426 Those who engage with an interdisciplinary perspective risk burning their fingers. This is especially true of legal scholars. Leslie Moran's experience resembles mine:

The multifarious gatekeepers of legal studies have responded in a variety of ways to scholarly and pedagogic projects that turn away from law's written text and its operationalization. In my experience from giving papers and talking to lawyers and judges, these range from bewilderment, disbelief and passive aggressive indifference to more open attacks and withering denuntiations that dismiss work that touches on the visual aspects of law as esoteric, trivial, "not law." 427

Such experiences make it imperative to shed more light on the digital dimension of law. Let me take this cue and conclude with some questions and brief answers (neither are final, of course):

- How far and how should interdisciplinary legal scholarship continue to explore visualization, audiovisualization, and multisensorization? It would be important for scholars to recognize the interconnectedness of these issues, which are studied by various basic legal disciplines and law-and areas. This paper marks a first attempt to demonstrate this interface in terms of visualization. Awareness of the similarities and differences between the basic legal disciplines and the law-and areas also needs to grow.

- To whom and how should such scholarship communicate its insights? I raise this question because most legal actors still only seem moderately interested in those matters - despite their relevance. It is of no use to publish if pertinent publications in legal journals and collected legal volumes do not reach a larger audience. It would make sense to publish scholarship on visualization, audiovisualization, and multisensorization also in non-legal media. A non-legal audience would probably respond more openly to these topics. It might therefore pressure the legal guild to take these issues seriously and to promote them rather than marginalize them.

- As my paper suggests, particulary the basic legal disciplines and law-and areas deal with visualization, audiovisualization, and multisensorization. In the future, will we need a discipline that encompasses all these disciplines and areas? I would say so. In the case of visualization, these would be visual law and legal communication design.

- Should law schools or design schools support legal design? And if so, how? Law schools and design schools should work together to establish curricula regarding visualization, audiovisualization, and multisensorization.

It is, of course, too premature for "final" answers and agree with Mulcahy's suggestion: "[...] before we can begin to talk of a visual turn we need to consider how to turn to the visual." ${ }^{428}$ Ex post, visual, audiovisual, and ultimately multisensory legal historians will perhaps offer later generations more sophisticated answers and undoubtedly raise further questions.

\section{References}

Adams, William M. The Future of Sustainability: Re-thinking Environment and Development in the Twenty-first Century, Report of the IUCN Renowned Thinkers Meeting, 29-31 January 2006. Gland: IUCN, 2006. https://portals.iucn.org/library/ node/12635 (last accessed November 30, 2020).

Almog, Shulamit. How Digital Technologies Are Changing the Practice of Law. Lewiston: The Edwin Mellen Press, 2007. Ashwin, Clive. "Drawing, Design and Semiotics." In Design Discourse: History, Theory, and Criticism, edited by Victor Margolin, 199-209. Chicago: The University of Chicago Press, 1989.

Ayaß, Ruth. "Editorial.” Österreichische Zeitschrift für Soziologie 37 (2012): 113-19.

426 Posner, 1317.

427 Moran, "Every Picture Speaks a Thousand Words," 431. See also Mulcahy, "Eyes of the Law," S117.

428 Mulcahy 2017, p. S128. 
—_. "Soziologie, visuelle.” In Wörterbuch der Soziologie, edited by Günter Endruweit, Gisela Trommsdorff, and Nicole Burzan, 496. $3^{\text {rd }}$ rev. ed. Munich: UVK, 2014.

Baer, Susanne. Rechtssoziologie: Eine Einführung in die interdisziplinäre Rechtsforschung. $3^{\text {rd }}$ ed. Baden-Baden: Nomos, 2017.

Bainbridge, Jason. "Visual Law: The Changing Signifiers of Law in Popular Visual Culture." In Prospects of Legal Semiotics, edited by Anne Wagner and Jan M. Broekman, 193-215. Dordrecht: Springer, 2010.

Barkan, Steven M., Barbara A. Bintliff, and Mary Whisner. Fundamentals of Legal Research. $10^{\text {th }}$ ed. St. Paul: LEG, 2015. Bauer, Elke. "Analoge Fotografie im digitalen Zeitalter. Eine Herausforderung für Bildarchive und Geschichtswissenschaft. Einleitung." Zeithistorische Forschungen/Studies in Contemporary History 12, issue 2 (2015): 314-16. https://doi. org/10.14765/zzf.dok-1442.

Becker-Moelands, Margariet A. "Die Erschliessung der ikonographischen Sammlung des Niederländischen Zentrums für rechtshistorische Dokumentation: Dokumentation oder wissenschaftliche Forschung?" In Forschungen zur Rechtsarchäologie und Rechtlichen Volkskunde, vol. 9, edited by Louis Carlen, 173-93. Zurich: Schulthess, 1987.

Behrmann, Carolin. "The Mirror Axiom: Legal Iconology and the Lure of Reflection.” In The Art of Law: Artistic Representations and Iconography of Law and Justice in Context, from the Middle Ages to the First World War, edited by Stefan Huygebaert, Georges Martyn, Vanessa Paumen, Eric Bousmar, and Xavier Rousseaux, 43-60. Cham: Springer, 2018.

Bently, Lionel. "Introduction.” In Law and the Senses: Sensational Jurisprudence, edited by Lionel Bently and Leo Flynn, 1-17. London: Pluto, 1996.

Bischoping, Katherine, Selom Chapman-Nyaho, and Rebecca Raby. "Linking Visuality to Justice through International Cover Designs for Discipline and Punish." The Annual Review of Interdisciplinary Justice Research 5 (2016): 180-215.

Boehme-Neßler, Volker. Pictorial Law: Modern Law and the Power of Pictures. Heidelberg: Springer, 2011.

Bove, Jens, and Karolin Schmahl. "Fotografische Nachlässe. Sammlungs- und Aktivierungsstrategien am Beispiel des Archivs der Fotografen in der Deutschen Fotothek." Zeithistorische Forschungen/Studies in Contemporary History 12, issue 2 (2015): 336-43. https://doi.org/10.14765/zzf.dok-1448.

Breckner, Roswitha. "Bildwahrnehmung - Bildinterpretation: Segmentanalyse als methodischer Zugang zur Erschließung bildlichen Sinns." Österreichische Zeitschrift für Soziologie 37 (2012): 143-64.

Brown, Tim. "Design Thinking.” Harvard Business Review (June 2008): 85-92.

Brown, Tim, and Barry Katz. “Change by Design.” Journal of Product Innovation Management 28, issue 3 (2011): $381-83$. Brunschwig, Colette R. "Die Forschungsstelle für Rechtsgeschichte im Spiegel alter und neuer Medien.” In Geschichte und Informatik, vol. 7/8, edited by Hannes Schüle, Peter Bär, and Gerold Ritter, 67-73. Bern: Verein "Geschichte und Informatik," 1996/1997.

—. Visualisierung von Rechtsnormen: Legal Design. Zurich: Schulthess, 2001.

"Legal Design and Web Based Legal Training: Evaluation von Visualisierungen im Web Based Training der Credit Suisse." In IT in Recht und Staat: Aktuelle Fragen der Rechtsinformatik 2002, edited by Erich Schweighofer, Thomas Menzel, and Günther Kreuzbauer, Schriftenreihe Rechtsinformatik, vol. 6, edited by Thomas Menzel and Günther Kreuzbauer, 297-308. Vienna: Verlag Österreich, 2002.

—_. "Legal Design and e-Government: Visualisations of Cost \& Efficiency Accounting in the wif! e-learning Environment of the Canton of Zurich (Switzerland)." In Electronic Government: First International Conference, EGOV 2002 Aix-enProvence, France, September 2-6, 2002, Proceedings, edited by Roland Traunmüller and Klaus Lenk, Lecture Notes in Computer Science, vol. 2456, edited by Gerhard Goos, Juris Hartmanis, and Jan van Leeuwen, 430-37. Berlin: Springer, 2002.

—. "Multisensory Law and Legal Informatics - A Comparison of How these Legal Disciplines Relate to Visual Law." Jusletter IT (February 22, 2011): marginal notes 166-170. https://jusletter-it.weblaw.ch/issues/2011/104/article_324. html_ONCE (last accessed November 30, 2020).

—. "Law Is not or Must Not Be Just Verbal and Visual in the $21^{\text {st }}$ Century: Toward Multisensory Law." In Internationalisation of Law in the Digital Information Society: Nordic Yearbook of Law and Informatics 2010-2012, edited by Dan Jerker B. Svantesson and Stanley Greenstein, 231-83. Copenhagen: Ex Tuto, 2013.

—. "On Visual Law: Visual Legal Communication Practices and Their Scholarly Exploration.” In Zeichen und Zauber des Rechts: Festschrift für Friedrich Lachmayer, edited by Erich Schweighofer, Meinrad Handstanger, Harald Hoffmann, Franz Kummer, Edmund Primosch, Günther Schefbeck, and Gloria Withalm, 899-933. Bern: Editions Weblaw, 2014. 
"Perspectives of Digital Law: Visualization, Audiovisualization, and Multisensorization." forum historiae iuris (May 7, 2019): marginal notes 1-97. https://doi.org/10.26032/fhi-2019-003.

—. "Contract Comics and the Visualization, Audio-Visualization, and Multisensorization of Law." University of Western Australia Law Review 46, issue 2 (2019): 191-217g, http://www.able.uwa.edu.au/centres/uwalr/issues/2019-volume-46,issue-2 (last accessed November 30, 2020).

—. "Humanoid Robots in Legal Education." In Yearbook for Legal Education 2018/19, edited by Bernhard Bergmans, 263-85. Berlin: Berliner Wissenschafts-Verlag, 2020.

—. "Humanoid robots for contract visualisation." UNIO - EU Law Journal 6, no. 1 (January 2020): 142-60. https:// revistas.uminho.pt/index.php/unio (last accessed November 30, 2020).

Buchanan, Richard. "Rhetoric, Humanism, and Design.” In Discovering Design: Explorations in Design Studies, edited by Richard Buchanan and Victor Margolin, 23-66. Chicago: The University of Chicago Press, 1995.

—. "Human Dignity and Human Rights: Thoughts on the Principles of Human-Centered Design." Design Issues 17, no. 3 (Summer 2001): 35-39.

—_. "Design Research and the New Learning." Design Issues 17, no. 4 (Autumn 2001): 3-23.

Burkhard, François. "Tendencies of German Design Theories in the Past Fifteen Years." In Design Discourse: History, Theory, Criticism, edited by Victor Margolin, 49-54. Chicago: The University of Chicago Press, 1989.

Burri, Regula Valérie. "Bilder als soziale Praxis: Grundlegungen einer Soziologie des Visuellen.” Zeitschrift für Soziologie 37, no. 4 (2007): 342-58.

—. "Visual rationalities: Towards a sociology of images." Current Sociology 60, no. 1 (2012): 45-60.

Cambridge Dictionary, "Legal services," https://dictionary.cambridge.org/dictionary/english/legal-services (last accessed November 30, 2020).

Case Western Reserve University, Weatherhead School of Management, "Faculty - Richard Buchanan," https://weatherhead.case.edu/faculty/george-buchanan (last accessed November 30, 2020).

Chandler, Daniel, and Rod Munday. A Dictionary of Media and Communication. Oxford: Oxford University Press, 2011. https:/www.oxfordreference.com/view/10.1093/acref/9780199568758.001.0001/acref-9780199568758-e-2972 (last accessed November 30, 2020).

Coates, Kathrin, and Andy Ellison. An introduction to information design. London: Laurence King Publishing, 2014.

Cooley, Mike. "Human-Centered Design.” In Information Design, edited by Robert Jacobson, 59-81. Cambridge: The MIT Press, 1999.

Crampton Smith, Gillian. "Foreword: What Is Interaction Design?" In Designing Interactions, edited by Bill Moggridge, vii-xi. Cambridge: The MIT Press, 2007.

Curtotti, Michael, Helena Haapio, and Stefania Passera. "Interdisciplinary Cooperation in Legal Design and Communication." In Co-operation, IRIS 2015, Proceedings of the $18^{\text {th }}$ International Legal Informatics Symposium, edited by Erich Schweighofer, Franz Kummer, and Walter Hötzendorfer, 455-62. Vienna: Österreichische Computer Gesellschaft \& Erich Schweighofer, 2015.

Curtotti, Michael Angelo. "Visualising a Visual Movement - Reflections on a Growing Body of Research." Journal of Open Access to Law 8, no. 1 (2020): 1-10. https://ojs.law.cornell.edu/index.php/joal (last accessed November 30, 2020).

D’Anjou, Philippe. Design Ethics beyond Duty and Virtue. Cambridge: Cambridge Scholars, 2017.

Dilnot, Clive. "The State of Design History, Part I.: Mapping the Field.” In Design Discourse: History, Theory, and Criticism, edited by Victor Margolin, 213-32. Chicago: The University of Chicago Press, 1989.

Dölemeyer, Barbara. “Dinge als Zeichen alten Rechts. Die Sammlung Frölich.” Rechtsgeschichte 4 (2004): 264-68.

Doherty, Michael. "Comprehensibility as a rule of law requirement: the role of legal design in delivering access to law." Journal of Open Access to Law 8, no. 1 (2020): 1-11. https://ojs.law.cornell.edu/index.php/joal (last accessed November 30, 2020).

Douzinas, Costas, and Lynda Nead. "Introduction." In Law and the Image, edited by Costas Douzinas and Lynda Nead, 1-15. Chicago: The University of Chicago Press, 1999.

Ducato, Rossana. "De iurisprudentia picturata: brief notes on law and visualization." Journal of Open Access to Law 7 , no. 1 (2019): 1-10. https://ojs.law.cornell.edu/index.php/joal/issue/view/8 (last accessed November 30, 2020).

Elkins, James. The Domain of Images. Ithaca: Cornell University Press, 1999. 
Endruweit, Günter. "Soziologie, Allgemeine und Spezielle.” In Wörterbuch der Soziologie, edited by Günter Endruweit, Gisela Trommsdorff, and Nicole Burzan, 487-88. $3^{\text {rd }}$ rev. ed. Munich: UVK, 2014.

Epstein, Richard A. "Let 'The Fundamental Things Apply': Necessary and Contingent Truths in Legal Scholarship." Harvard Law Review, 115, no. 5 (March 2002): 1288-1313.

Erdelez, Sanda, and Sheila O'Hare. "Legal Informatics: Application of Information Technology in Law." In Annual Review of Information Science and Technology (ARTIST), vol. 32, edited by Martha E. Williams, 367-402. Medford: Information Today, 1997.

Estermann, Josef. "Rechtssoziologie.” VSH-Bulletin 1 (April 2014): 63-69.

Fehr, Hans. Das Recht im Bilde. Erlenbach-Zurich: Eugen Rentsch, 1923.

Feigenson, Neal, and Christina Spiesel. Law on Display: The Digital Transformation of Legal Persuasion and Judgment. New York: New York University Press, 2009.

Fenwick, Mark, Wulf Kaal, and Erik P. Vermeulen. "Legal Education in a Digital Age: Why Coding Matters for the Lawyer of the Future." In Legal Tech and the New Sharing Economy, edited by Marcelo Corrales Compagnucci, Nikolaus Forgó, Toshiyuki Kono, Shinto Teramoto, and Erik P. M. Vermeulen, 103-22. Singapore: Springer, 2020.

Friedman, Lawrence M. "Legal Culture and Social Development." Law \& Society Review 4, no. 1 (August 1969): $29-44$.

—_. "Law, Lawyers, and Popular Culture." The Yale Law Journal 98, issue 8 (1989): 1579-1606.

Frug, Sara. "Toward Inclusive Design for Visual Law.” Journal of Open Access to Law 7, no. 1 (2019): 1-11, https://ojs. law.cornell.edu/index.php/joal/issue/view/8 (last accessed November 30, 2020).

Funke, Andreas. "Rechtstheorie." In Grundlagen des Rechts, edited by Julian Krüper, 45-66, marginal numbers 1-54. $3^{\text {rd }}$ ed. Baden-Baden: Nomos, 2017.

Gies, Lieve. "The media and public understanding of the law." In Readings in Law and Popular Culture, edited by Steve Greenfield andGuy Osborn, 65-87. London: Routledge, 2006.

Götters, Karl-Heinz. Einführung in die Stilistik. Weinheim: W. Fink, 2004.

Graber, Christoph Beat. "Legal Sociology." In Introduction to Swiss Law, edited by Marc Thommen, 109-34. Berlin: Carl Grossmann, 2018.

Gräf, Holger Th. "Historische Bildkunde." Archiv für Diplomatik, Schriftgeschichte, Siegel- und Wappenkunde 54 (2008): 379-98.

Grady, John. "The Scope of Visual Sociology." Visual Sociology 11, no. 2 (1996): 10-24.

__. "Becoming a Visual Sociologist." Sociological Imagination 38, no. 1/2 (2001): 83-119.

"Visual Sociology." In 21st Century Sociology: A Reference Handbook, vol. 2, edited by Clifton D. Bryant/Dennis L. Peck (eds.), 63-70. Thousand Oaks: Sage, 2007.

Grimm, Paul W., Joseph G. Petrosinelli, and David Faust. “Tips for Daubert Motions from a Judge, an Attorney, and a Behavioral Scientist." In Coping with Psychiatric and Psycholegal Testimony, edited by David Faust, 995-1004. New York: Oxford University Press, 2011.

Haapio, Helena. "Making Contracts Work for Clients: Towards Greater Clarity and Usability." In Transformation of Legal Languages, IRIS 2012, Proceedings of the $15^{\text {th }}$ International Legal Informatics Symposium, edited by Erich Schweighofer, Franz Kummer, and Walter Hötzendorfer, 389-96. Vienna: Österreichische Computer Gesellschaft, 2012.

Haapio, Helena, Daniela Alina Plewe, and Robert de Rooy. "Next Generation Deal Design: Comics and Visual Platforms for Contracting." In Networks, IRIS 2016, Proceedings of the $19^{\text {th }}$ International Legal Informatics Symposium, edited by Erich Schweighofer, Franz Kummer, Walter Hötzendorfer, and Georg Borges, 373-80. Vienna: Österreichische Computer Gesellschaft \& Erich Schweighofer, 2016.

Haapio, Helena, and Margaret Hagan. "Design Patterns for Contracts." In Networks, IRIS 2016, Proceedings of the $19^{\text {th }}$ International Legal Informatics Symposium, edited by Erich Schweighofer, Franz Kummer, Walter Hötzendorfer, and Georg Borges, 381-88. Vienna: Österreichische Computer Gesellschaft \& Erich Schweighofer, 2016.

Hagan, Margaret D. "A Human-Centered Design Approach to Access to Justice: Generating New Prototypes and Hypotheses for Intervention to Make Courts User-Friendly." Indiana Journal of Law and Social Equality 6, issue 2 (2018): 199-239.

__. "Participatory Design for Innovation in Access to Justice." Daedalus 148, issue 1 (2019): 120-27.

—. "The Justice is in the Details: Evaluating Self-Help Designs for Legal Capability in Traffic Court." Journal of Open Access to Law 7, no. 1 (2019): 1- 16. https://ojs.law.cornell.edu/index.php/joal/issue/view/8 (last accessed November 30, 2020). 
—. "Legal Design as a Thing: A Theory of Change and a Set of Methods to Craft a Human-Centered Legal System." Design Issues 36, no. 3 (Summer 2020): 3-15.

—. Law by Design. s.1.: s.n., 2020. https://www.lawbydesign.co/legal-design/ (last accessed November 30, 2020).

Haller, Sabine. Dienstleistungsmanagement: Grundlagen - Konzepte-Instrumente. $7^{\text {th }}$ rev. ed. Wiesbaden: Springer, 2017. Harland, Robert. “The Dimensions of Graphic Design and Its Spheres of Influence.” Design Issues 27, no. 1 (Winter 2011): 21-34.

Hamilton, Sheryl N., Diana Majury, Dawn Moore, and Neil Sargent. “Sensing law: Introduction.” In Sensing Law, edited by Sheryl N. Hamilton, Diana Majury, Dawn Moore, Neil Sargent, and Christiane Wilke, 1-23. Abingdon: Routledge, 2017. Harper, Douglas. "Visual Sociology: Expanding Sociological Vision.” The American Sociologist (Spring 1988): 54-70.

- Visual Sociology. London: Routledge, 2012.

Henze, Raphaela. Bildmedien im juristischen Unterricht. Berlin: Tenea, 2003.

Hesse, Hans Albrecht. Einführung in die Rechtssoziologie. Wiesbaden: VS Verlag für Sozialwissenschaften, 2004.

Hibbitts, Bernard J. "Making Sense of Metaphors: Visuality, Aurality, and the Reconfiguration of American Legal Discourse." Cardozo Law Review 16, issue 2 (December 1994): 229-356.

—. "Senses of Difference: A Sociology of Metaphors in American Legal Discourse." In Law and the Senses: Sensational Jurisprudence, edited by Lionel Bently and Leo Flynn, 97-122. London: Pluto, 1996.

Hickman, Larry. Philosophy, Technology, and Human Affairs. Texas: IBIS Press of College Station, 1985.

Hoad, Terry F., ed. The Concise Oxford Dictionary of English Etymology. Oxford: Oxford University Press, 1996. https:/www.oxfordreference.com/view/10.1093/acref/9780192830982.001.0001/acref-9780192830982-e-12784?rskey= H2HYtv\&result=12785 (last accessed November 30, 2020).

Horn, Robert E. “Information Design: Emergence of a New Profession.” In Information Design, edited by Robert Jacobson, 15-33. Cambridge: The MIT Press, 1999.

IxDA and Digital Works, "INTERACTION eleven, February 9-12 : Boulder Colorado," https://interaction11.ixda.org/ index-2.html (last accessed November 30, 2020).

Jackson, Dan. "Human-centered legal tech: integrating design in legal education." The Law Teacher 50, no. 1 (2016): 82-87.

Jacobson, Robert. "Introduction: Why Information Design Matters.” In Information Design, edited by Robert Jacobson, 1-10. Cambridge: The MIT Press, 1999.

Joost, Geesche. "Audio-visuelle Rhetorik und Informationsdesign." In Knowledge Media Design: Theorie, Methodik, Praxis, edited by Maximilian Eibl, Harald Reiterer, Peter Friedrich Stephan, and Frank Thissen, 211-24. $2^{\text {nd }}$ rev. ed. Munich: Oldenbourg, 2006.

Katsh, Ethan M. Law in a Digital World. New York: Oxford University Press, 1995.

Kaufmann, Arthur. "Rechtsphilosophie, Rechtstheorie, Rechtsdogmatik." In Einführung in die Rechtsphilosophie und Rechtstheorie der Gegenwart, edited by Arthur Kaufmann, Winfried Hassemer, and Ulfried Neumann, 1-25. $8^{\text {th }}$ rev. ed. Heidelberg: C.F. Müller, 2011.

Klein, David, and Ken Phillips. "Sustainable Design: An Educational Imperative." The Journal of Technology Studies 37, no. 1/2 (Spring/Fall 2011): 69-77.

Kleinhietpaß, Cordula M. Metaphern der Rechtssprache und ihre Verwendung für Visualisierungen. Berlin: Tenea, 2005.

Köbler, Gerhard. Bilder aus der deutschen Rechtsgeschichte: Von den Anfängen bis zur Gegenwart. Munich: C. H. Beck, 1988.

Kocher, Gernot. Zeichen und Symbole des Rechts: Eine historische Ikonographie. Munich: C. H. Beck, 1992.

—. "Die Rechtsikonographie." In Die Wolfenbütteler Bilderhandschrift des Sachsenspiegels, Aufsätze und Untersuchungen: Kommentarband zur Faksimile-Ausgabe, edited by Ruth Schmidt-Wiegand, 107-17. Berlin: Akademie-Verlag, 1993.

—. "Bilder: Eine Nebenquelle der Rechtsgeschichte?" In Festschrift für Wilhelm Brauneder zum 65. Geburtstag: Rechtsgeschichte mit internationaler Perspektive, edited by Gerald Kohl, Christian Neschware, and Thomas Simon, 22328. Vienna: Manz, 2008.

_. "Die Stellung der Heidelberger Bilderhandschrift innerhalb der Codices picturati." In Eike von Repgow Sachsenspiegel, Die Heidelberger Bilderhandschrift Cod. Pal. Germ. 164, Vollständige Faksimile-Ausgabe im Originalformat der 
Handschrift aus der Universitätsbibliothek Heidelberg, Kommentarband, edited by Gernot Kocher and Dietlinde MunzelEverling, 21-22. Graz: Akademische Druck- u. Verlagsanstalt, 2010.

—_. "Das Landrecht des Sachsenspiegels." In Eike von Repgow Sachsenspiegel, Die Heidelberger Bilderhandschrift Cod. Pal. Germ. 164, Vollständige Faksimile-Ausgabe im Originalformat der Handschrift aus der Universitätsbibliothek Heidelberg, Kommentarband, edited by Gernot Kocher and Dietlinde Munzel-Everling, 63-71. Graz: Akademische Druck- u. Verlagsanstalt, 2010.

Koyama, Yuki, and Takeo Igarashi. "Computational Design with Crowds.” In Computational Interaction, edited by Antti Oulasvirta, Per Ola Kristenssson, Xiaojun Bi, and Andrew Howes, 153-84. Oxford: Oxford University Press, 2018.

Krapp, Andreas, Manfred Prenzel, and Bernd Weidenmann. "Geschichte, Gegenstandsbereich und Aufgaben der Pädagogischen Psychologie.” In Pädagogische Psychologie: Ein Lehrbuch, edited by Andreas Krapp and Bernd Weidenmann, 1-31. $5^{\text {th }}$ completely rev. ed. Weinheim: Beltz, 2006.

Kunz, Karl-Ludwig, and Martino Mona. Rechtsphilosophie, Rechtstheorie und Rechtssoziologie: Eine Einführung in die theoretischen Grundlagen der Rechtswissenschaft. $2^{\text {nd }}$ newly rev. and complemented ed. Bern: Haupt, 2015.

Langer, Thomas. Die Verbildlichung der juristischen Ausbildungsliteratur. Berlin: Tenea, 2004.

Langer, Inghard, Friedemann Schulz von Thun, and Reinhard Tausch. Sich verständlich ausdrücken. $7^{\text {th }}$ rev. and expanded ed. Munich: Ernst Reinhardt, 2002.

Laufs, Adolf. "Die Fehrsche rechtsarchäologische Bildersammlung." In Aus der Arbeit des Archivars. Festschrift für Eberhard Gönner, edited by Gregor Richter, 361-74. Stuttgart: Staatliche Archivverwaltung Baden-Württemberg, 1986.

Legat, Anneliese. Bildquellen als Informationsträger in der Rechtsgeschichte: Eine wissenschaftstheoretische Untersuchung. Graz: [no publisher], 1995.

Levinson, Sanford. "Democracy in a New America: Some Reflections on a Title." North Carolina Law Review 79, no. 5 (2001): 1559-67.

Lidwell, William, Kritina Holden, and Jill Butler. Universal Principles of Design: 125 Ways to Enhance Usability, Influence, Perception, Increase Appeal, Make Better Design Decisions, and Teach through Design. Beverly: Rockport, 2003.

Lipton, Ronnie. The Practical Guide to Information Design. Hoboken: John Wiley \& Sons, 2007.

Little, David. "Explanatory Autonomy and Coleman's Boat.” Theoria: An International Journal for Theory, History and Foundations of Science, SEGUNDA EPOCA 27, no. 2/74 (May 2012): 137-51.

Lück, Heiner. Der Sachsenspiegel: Das berühmteste deutsche Rechtsbuch des Mittelalters. Darmstadt: Wissenschaftliche Buchgesellschaft, 2017.

McLeod, Ian. Legal Theory. $6^{\text {th }}$ ed. London: Palgrave Macmillan, 2012.

Mahlmann, Matthias. "Legal Philosophy and Legal Theory." In Introduction to Swiss Law, edited by Marc Thommen, 83-107. Berlin: Carl Grossmann, 2018.

Maldonado, Tomás. Digitale Welt und Gestaltung: Ausgewählte Schriften. Edited and translated by Gui Bonsiepe. Basel: Birkhäuser, 2007.

Manchester, A. H., and M. A. Becker-Moelands. “An Introduction to Iconographical Studies of Legal History.” In Legal History in the Making, edited by William M. Gordon and T. D. Fergus, 85-94. London: The Hambledon Press, 1991.

Margolin, Victor. "The Product Milieu and Social Action.” In Discovering Design: Explorations in Design Studies, edited by Richard Buchanan and Victor Margolin, 121-45. Chicago: The University of Chicago Press, 1995.

Martin, Robert C. Clean Architecture: A Craftman's Guide to Software Structure and Design. Boston: Prentice Hall, 2018. Martyn, Georges, and Stefan Huygebaert. "Twenty New Contributions to the Upcoming Field of Historical Legal Iconology." In The Art of Law: Artistic Representations and Iconography of Law and Justice in Context, from the Middle Ages to the First World War, edited by Stefan Huygebaert, Georges Martyn, Vanessa Paumen, Eric Bousmar, and Xavier Rousseaux, 3-24. Cham: Springer, 2018.

Melone, Mirco. "Kommerz-Geschichte. Historische Pressefotografie zwischen Profit und Politik." Zeithistorische Forschungen/Studies in Contemporary History 12, issue 2 (2015): 326-35. https://doi.org/10.14765/zzf.dok-1442.

Mezey, Naomi. “The Image Cannot Speak for Itself: Film, Summary Judgement, and Visual Literacy.” Valparaiso University Law Review 48, no. 1 (Fall 2013): 1-40. 
Mik, Elisa. “The Limits of Visual Law.” Journal of Open Access to Law 8, no. 1 (2020): 1-13. https://ojs.law.cornell.edu/ index.php/joal (last accessed November 30, 2020).

Mitcham, Carl. "Ethics into Design.” In Discovering Design: Explorations in Design Studies, edited by Richard Buchanan and Victor Margolin, 173-89. Chicago: The University of Chicago Press, 1995.

Moran, Leslie J. "Every Picture Speaks a Thousand Words: Visualizing Judicial Authority in the Press.” In Intersections of Law and Culture, edited by Priska Gisler, Sara Steinert Borella, and Caroline Wiedmer, 31-49. New York: Palgrave Macmillan, 2012.

Mulcahy, Linda. Legal architecture: Justice, due process and the place of law. Abingdon, Oxon: Routledge, 2011.

—. "Eyes of the Law: A Visual Turn in Socio-Legal Studies?" Journal of Law and Society 44, issue S1 (2017): S111S128.

Mulcahy, Linda, and Emma Rowden. The Democratic Courthouse: A Modern History of Design, Due Process and Dignity. Abingdon, Oxon: Routledge, 2020.

Nathansohn, Regev, and Dennis Zuev. "Sociology of the Visual Sphere: Introduction.” In Sociology of the Visual Sphere, edited by Regev Nathansohn and Dennis Zuev, 1-9. New York: Routledge, 2013.

Navas, Susana. "The Provision of Legal Services to Consumers Using LawTech Tools: From 'Service' to 'Legal Product.'” Open Journal of Social Sciences 7 (2019): 79-103.

Newcomb, Matthew. "Sustainability as a Design Principle for Composition: Situational Creativity as a Habit of Mind." College Composition and Communication 63, no. 4 (June 2012): 593-615.

Norman, Donald. The Design of Everyday Things. Rev. and expanded ed. New York: Basic Books, 2013.

Orel, Tifan. "Designing Self-Diagnostic, Self-Cure, Self-Enhancing, and Self-Fashioning Devices." In Discovering Design: Explorations in Design Studies, edited by Richard Buchanan and Victor Margolin, 77-104. Chicago: The University of Chicago Press, 1995.

Oxford Reference, “Overview: ocularcentrism," https://www.oxfordreference.com/view/10.1093/oi/authority.20110803100245338 (last accessed November 30, 2020).

Palmirani, Monica, Arianna Rossi, Michele Martoni, and Margaret Hagan. “A Methodological Framework to Design a Machine-Readable Privacy Icon Set." In Data Protection / LegalTech: Proceedings of the $21^{\text {st }}$ International Legal Informatics Symposium IRIS 2018, edited by Erich Schweighofer, Franz Kummer, Ahti Saarenpää, and Burkhard Schafer, $451-54$. Bern: Editions Weblaw \& Erich Schweighofer, 2018.

Passera, Stefania, and Helena Haapio. "Transforming Contracts from Legal Rules to User-centered Communication Tools: a Human-Information Interaction Challenge.” Communication Design Quarterly 1 (3 April 2013): 38-45.

Passini, Romedi. "Information Design: An Old Hag in Fashionable Clothes?" In Information Design, edited by Robert Jacobson, 83-98. London: The MIT Press, 1999.

Paul, Gerhard. "Von der Historischen Bildkunde zur Visual History. Eine Einführung.” In Visual History, Ein Studienbuch, edited by Gerhard Paul, 7-36. Göttingen: Vandenhoek \& Ruprecht, 2006.

—. "Visual History, Version: 3.0." Docupedia-Zeitgeschichte (13.03.2014): 1-24. DOI: http://dx.doi.org/10.14765/zzf. dok.2.558.v3.

Penner, James, David Schiff, and Nobles Richard. "Approaches to Jurisprudence, Legal Theory, and the Philosophy of Law." In Introduction to Jurisprudence and Legal Theory: Commentary and Materials, edited by James Penner, David Schiff, and Richard Nobles, 3-34. Oxford: Oxford University Press, 2005.

Perlmutter, David D. "Visual Historical Methods: Problems, Prospects, Applications." Historical Methods 27, no. 4 (Fall 1994): 167-84.

Perry-Kessaris, Amanda. "Legal Design for Practice, Activism, Policy, and Research.” Journal of Law and Society 46, no. 2 (June 2019): 185-210.

Peter Junkermann Verlag, "SIGNA IURIS," https://www.signa-iuris.de/200si_ueber.html (last accessed November 30, 2020).

Pettersson, Rune. Information Design: An introduction [sic]. Amsterdam: John Benjamins, 2002.

Pfeiffer, Michel. "Wie können Bildbestände bewertet werden? Auswahl-, Erhaltungs- und Vermittlungsstrategien im Rahmen von Digitalisierungsprojekten.” Zeithistorische Forschungen/Studies in Contemporary History 12, issue 2 (2015): 317-25. https://doi.org/10.14765/zzf.dok-1443. 
Pleister, Wolfgang, and Wolfgang Schild, eds. Recht und Gerechtigkeit im Spiegel der europäischen Kunst. Cologne: DuMont, 1988.

Porter, Elisabeth G. “Taking Images Seriously.” Columbia Law Review 144, no. 7 (November 2014): 1687-1782.

Posner, Richard A. "Legal Scholarship Today.” Harvard Law Review 115, no. 5 (March 2002): 1314-26.

Potacs, Michael. Rechtstheorie. $2^{\text {nd }}$ ed. Vienna: facultas, 2019.

Preisendörfer, Peter. Organisationssoziologie. Wiesbaden: Springer, 2011.

Prinz, Franziska. Der Bildgebrauch in gedruckten Rechtsbüchern des 15. bis zum Ausgang des 18. Jahrhunderts. Hamburg: LIT Verlag, 2006.

Raab, Jürgen. "Visuelle Wissenssoziologie der Fotografie: Sozialwissenschaftliche Analysearbeit zwischen Einzelbild, Bildkontexten und Sozialmilieu." Österreichische Zeitschrift für Soziologie 37 (2012): 121-42.

Raiser, Thomas. Grundlagen der Rechtssoziologie. $6^{\text {th }}$ rev. and expanded ed. of Das lebende Recht. Tuebingen: Mohr Siebeck, 2013.

Rakoff, Todd D. “Introduction.” Harvard Law Review 115, no. 5 (March 2002): 1278-87.

Rehbinder, Manfred. Rechtssoziologie. $8^{\text {th }}$ ed. Munich: C. H. Beck, 2014.

Repgow, Eike von. The Saxon Mirror. Translated by Maria Dobozy. Philadelphia: University of Pennsylvania Press, 1999. Rhode, Deborah L. "Legal Scholarship." Harvard Law Review 115, no. 5 (March 2002): 1327-61.

Ritzer, George. "The Rise of Micro-Sociological Theory.” Sociological Theory 3, no. 1 (Spring 1985): 88-98.

Rodell, Fred. "Good Bye to Law Reviews." Virginia Law Review 23 (1936-1937): 38-45.

Röhl, Klaus F., "Das Recht im Zeichen der Globalisierung." In Von den "Neuen Medien” zu Multimedia: Gesellschaftliche und politische Aspekte, Dokumentation der Tagung Medien und Gesellschaft im Spannungsfeld von Technik, Ökonomie und Recht 21. - 22. November 1997, edited by Manfred Mai and Klaus Neumann-Braun, Duesseldorf, 75-92. Baden-Baden: Nomos, 1998.

—_. "Das Recht nach der visuellen Zeitenwende." JZ 7 (2003): 339-44.

Röhl Klaus F., and Stefan Ulbrich. "Visuelle Rechtskommunikation." Zeitschrift für Rechtssoziologie 21, no. 2 (2001): 355-85.

Röhl, Klaus F., and Hans Christian Röhl. Allgemeine Rechtslehre: Ein Lehrbuch. $3^{\text {rd }}$ rev. ed. Cologne: Heymann, 2008.

Ross, Richard J. "Communications Revolutions and Legal Culture: An Elusive Relationship." Law \& Social Inquiry 27, issue 3 (July 2002): 637-84.

Rossi, Arianna. "Legal Design for the General Data Protection Regulation: A Methodology for the Visualization and Communication of Legal Concepts." PhD diss. University of Luxembourg, 2019. https://orbilu.uni.lu/handle/10993/39925 (last accessed November 30, 2020).

Rossi, Arianna, and Monica Palmirani. "Can Visual Design Provide Legal Transparency? The Challenges for Successful Implementation of Icons for Data Protection.” Design Issues 36, no. 3 (Summer 2020): 82-96.

Santuber, Joaquín, Lina Krawietz, Babajide Owoyele, and Johnathan A. Edelman. "A Framework Theory of Legal Design for the Emergence of Change in the Digital Legal Society." Rechtstheorie 50 (2019): 41-57.

Sarat, Austin, Matthew Anderson, and Cathrine O. Frank. "Introduction: On the Origins and Prospects of the Humanistic Study of Law." In Law and the Humanities: An Introduction, edited by Austin Sarat, Matthew Anderson, and Cathrine O. Frank, 1-46. Cambridge: Cambridge University Press, 2010.

Sauer, Heiko. "Juristische Methodenlehre.” In Grundlagen des Rechts, edited by Julian Krüper, 176-96, marginal notes 1-44. $3^{\text {rd }}$ ed. Baden-Baden: Nomos, 2017.

Schild, Wolfgang. Bilder von Recht und Gerechtigkeit. Cologne: DuMont, 1995.

Schmoeckel, Mathias. "Karl von Amira und die Anfänge der Rechtsarchäologie - Die rechtsarchäologische Sammlung am Leopold-Wenger-Institut." In Forschungen zur Rechtsarchäologie und Rechtlichen Volkskunde, vol. 17, edited by Louis Carlen, 67-81. Zurich: Schulthess, 1997.

Schnettler, Bernt, and Alejandro Baer. "Perspektiven einer visuellen Soziologie: Schlaglichter und blinde Flecken einer aktuellen soziologischen Debatte." Soziale Welt 64, issue 1-2 (2013): 7-15.

Sheppard, Stephen R. J. "Validity, reliability, and ethics in visualization." In Visualization in Landscape and Environmental Planning: Technology and Applications, edited by Ian Bishop and Eckart Lange, 70-97. London: Taylor \& Francis, 2005. 
Sherwin, Richard K. When Law Goes Pop: The Vanishing Line between Law and Popular Culture. Chicago: The University of Chicago Press, 2002.

—. Visualizing Law in the Age of the Digital Baroque: Arabesques and Entanglements. London: Routledge, 2011.

Siapera, Eugenia. Understanding New Media. Los Angeles: Sage, 2018.

Silbey, Jessica. "Images in/of Law.” New York Law School Law Review 57 (2012-2013): 171-84.

Silbey, Susan S. "Legal culture and cultures of legality." In Handbook of Cultural Sociology, edited by John R. Hall, Laura Grindstaff, and Ming-Cheng Lo, 426-445. London: Routledge, 2010.

Solarte-Vasquez, Maria Claudia, and Petra Hietanen-Kunwald. "Responsibility and Responsiveness in the Design of Digital and Automated Dispute Resolution Processes." In Responsible Digitalization, IRIS 2020, Proceedings oft he $23^{\text {rd }}$ International Legal Informatics Symposium, edited by Erich Schweighofer, Walter Hötzendorfer, Franz Kummer, and Ahti Saarenpää, 451-58. Bern: Editions Weblaw, Bern 2020.

Stegmaier, Peter. "Recht und Normativität aus soziologischer Perspektive." In Grundlagen des Rechts, edited by Julian Krüper, 67-90, marginal notes 1-72. $3^{\text {rd }}$ edition. Baden-Baden, Nomos: 2017.

Stowasser, Josef M., Michael Petschenig, and Franz Skutsch. Der Kleine Stowasser: Lateinisch-Deutsches Schulwörterbuch. $3^{\text {rd }}$ ed. R. Munich: Oldenburg, 1991.

Straten, Roelof van. An Introduction to Iconography. Translated by Patricia de Man. London: Taylor \& Francis, 1994/2000.

Struck, Gerhard. Rechtssoziologie: Grundlagen und Strukturen. Baden-Baden, Nomos: 2011.

Torres, Gerald. "Translation and Stories.” Harvard Law Review 115, no. 5 (March 2002): 1362-95.

Ulrich, Karl T., and Steven D. Eppinger. Product Design and Development. $6^{\text {th }}$ ed. New York: McGrawHill Education, 2016.

Vesting, Thomas. Legal Theory. Translated by Aaron Choichet. Munich, C. H. Beck, 2018.

Wacks, Raymond. Understanding Jurisprudence: An Introduction to Legal Theory. $4^{\text {th }}$ ed. Oxford: Oxford University Press, 2015.

Wagner, Jon. "Contrasting images, complementary trajectories: sociology, visual sociology and visual research." Visual Studies 17, no. 2 (2002): 160-71.

Walby, Kevin. "Reflections on Visual Methods from a Study of Manitoulin Island's Penal History Museums." The Annual Review of Interdisciplinary Justice Research 5 (2016): 264-90.

Weber-Grellet, Heinrich. Rechtsphilosophie und Rechtstheorie. $6^{\text {th }}$ rev. ed. Muenster: Alpmann Schmidt, 2014.

Wexler, David. "Two Decades of Therapeutic Jurisprudence.” Touro Law Review 24 (2008): 17-29.

Widener, Michael, and Mark S. Weiner. Law's Picture Books: The Yale Law Library Collection. Clark: Talbot, 2017.

Wohlfeil, Rainer. "Das Bild als Geschichtsquelle.” Historische Zeitschrift 243 (1986): 91-100.

Woody, Li. [中文字幕]IxD 11_Richard Buchanan_4 order of design_交互設計的四個維度, YouTube video, 53:12, May 13, 2013, https://www.youtube.com/watch?v=0W6O7OIIkog, (last accessed November 30, 2020).

Wimböck, Gabriele. "Historische Bildforschung." In Metzler Lexikon der Kunstwissenschaft: Ideen, Methoden, Begriffe, edited by Ulrich Pfisterer, 175-79. $2^{\text {nd }}$ edition. Berlin: Springer, 2020.

Zaccai, Gianfranco. “Art and Technology: Aesthetics Redefined.” In Discovering Design: Explorations in Design Studies, edited by Richard Buchanan and Victor Margolin), 3-12. Chicago: The University of Chicago Press, 1995.

Zhao, Li, and Shuhu Zhang. "Development of Visual Philosophy under Impact of Philosophy of Technology." Journal of Educational Technology Development and Exchange 6, issue 2 (2013): 29-38.

\section{Acknowledgments}

I am grateful to Dr. Mark Kyburz for editing this paper. I wish to extend my gratitude to Professor Dr. Dr. Erich Schweighofer for inviting me to hold the first keynote lecture at the International Legal Informatics Symposion 2020, University of Salzburg, Austria. My talk prompted me to write this paper. I also thank Professor Dr. Helena Haapio for her greatly appreciated references. For the sake of concision, I have translated passages from German texts and refer readers to the original versions via the respective page numbers. 